Columbia Law School

Scholarship Archive

\title{
Who's Afraid of Section 1498? A Case for Government Patent Use in Pandemics and Other National Crises
}

Christopher J. Morten

Columbia Law School, cjm2002@columbia.edu

Charles Duan

R Street Institute, cduan@rstreet.org

Follow this and additional works at: https://scholarship.law.columbia.edu/faculty_scholarship

Part of the Health Law and Policy Commons, and the Intellectual Property Law Commons

\section{Recommended Citation}

Christopher J. Morten \& Charles Duan, Who's Afraid of Section 1498? A Case for Government Patent Use in Pandemics and Other National Crises, 23 YALE J. L. \& TECH. 1 (2020).

Available at: https://scholarship.law.columbia.edu/faculty_scholarship/2810

This Article is brought to you for free and open access by the Faculty Publications at Scholarship Archive. It has been accepted for inclusion in Faculty Scholarship by an authorized administrator of Scholarship Archive. For more information, please contact scholarshiparchive@law.columbia.edu. 
Yale Journal of Law \& Technology

Volume 23, Fall 2020

\title{
Who's Afraid OF SECTION 1498? A CASE FOR Government Patent Use in Pandemics And Other National CRISES
}

\author{
Christopher J. Morten \& Charles Duan*
}

COVID-19 has created pressing and widespread needs for vaccines, medical treatments, PPE, and other medical technologies, needs that may conflict-indeed, have already begun to conflictwith the exclusive rights conferred by United States patents. The U.S. government has a legal mechanism to overcome this conflict: government use of patented technologies at the cost of governmentpaid compensation under 28 U.S.C. \$ 1498. But while many have recognized the theoretical possibility of government patent use under that statute, there is today a conventional wisdom that $\$ 1498$ is too exceptional, unpredictable, and dramatic for practical use, to the point that it ought to be invoked sparingly or not at all, even in extraordinary circumstances such as a pandemic.

Yet that conventional wisdom is a recent one, and it conflicts with both history and theory. This Article considers the role of $\S 1498$ in the context of national crises and emergencies like

\footnotetext{
* Copyright 2020 Christopher J. Morten and Charles Duan. Morten is the deputy director of the Technology Law and Policy Clinic and a Fellow at the Engelberg Center on Innovation Law \& Policy at New York University School of Law. He is also a Visiting Fellow of the Yale Global Health Justice Partnership and an Affiliated Fellow of the Information Society Project at Yale Law School. Duan is a Senior Fellow at the R Street Institute, Washington, D.C. Order of authorship was determined by coin flip. Portions of this Article are based on Who's Afraid of Section 1498? Government Patent Use as Versatile Policy Tool, WRITTEN DESCRIPTION (Apr. 24, 2020,), https://writtendescription.blogspot.com/2020/04/ whos-afraid-of-section-1498-government.html. The authors would like to thank Al Engelberg, Daniel Hemel, Amy Kapczynski, Priti Krishtel, Matthew Lane, Lisa Larrimore Ouellette, Zain Rizvi, Bhaven Sampat, Jason Schultz, Ken Shadlen, Kathy Strandburg, Jacob Victor, and the editors of the Yale Journal of Law and Technology for their valuable insights and assistance that contributed to this Article. C.J.M. gratefully acknowledges Kara Smith (NYU Law '22) for research support. All errors are the authors' own.
} 
COVID-19, a context so far not addressed substantially in the literature on the statute. We find that government patent use is not nearly as exceptional as it is commonly made out to be, and indeed has been not only used but expanded through statutory amendment over the last century. Review of the development and use of the statute during both world wars and the post-September 11 period reveals widespread acceptance of government patent use as a tool for addressing imminent national problems, and it illuminates particular features of government patent use that become especially pertinent in times of crisis. In the United States, government patent use and national emergencies have a close and special relationship; each has shaped the other.

Drawing from the lessons of history and analysis of the statute, we develop a novel framework for comparing \& 1498 to other policy tools, including prizes, research grants, and patent buyouts. Under this framework, four features of $\$ 1498$ stand out: speed of invocation, flexibility in the scope of its use, post-crisis determination of compensation, and use of an impartial adjudicator. Whenever these four features are advantageous - which will be true in most national emergency situations, as we demonstrate-the U.S. government should strongly consider government patent use over patent buyouts and other policy tools. We show the advantages of these four features in a case study: government patent use to expand supply and access to the COVID-19 treatment remdesivir. Accordingly, and contrary to the conventional view of $\$ 1498$, we conclude that government patent should be an ordinary tool of government policy. 


\section{TABLE OF CONTENTS}

INTRODUCTION

I. Historical Role of Government Patent USE In Times

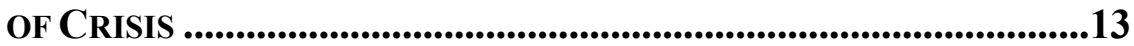

A. Origin of the Statute .........................................................13

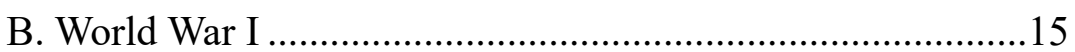

C. World War II ........................................................................20

D. Bioterrorism Threats After September 11 .........................26

E. Lessons for the COVID-19 Pandemic.................................33

II. The Government's InNOVATION POLICY TOOLBOX ............39

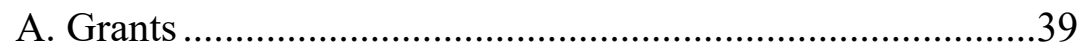

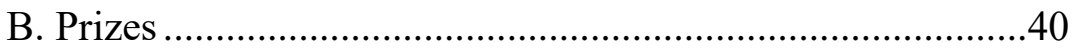

C. Patent Buyouts.................................................................41

D. Government Patent Use Under Section 1498 ....................43

III. Section 1498 As Policy Tool in a National

EMERGENCY ..................................................................50

A. Four Key Features of Government Patent Use in a National

Emergency .......................................................................51

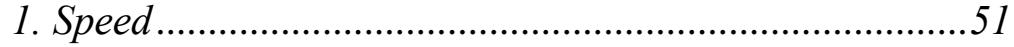

2. Flexibility ....................................................................54

3. Ex Post Remedy Determination ..................................61 61

4. Determination of Compensation by an Impartial Adjudicator ....................................................................66

B. A Case Study for the Use of $\S 1498$ : Remdesivir in the COVID-19 Pandemic ........................................................69

1. Remdesivir: An Experimental Drug That Promises

Modest but Important Benefits.......................................... 71

2. Two Problems: Shortages and Overpricing....................74

3. Patents Are the Sole Significant Barrier to Access ........ 78

4. Government Patent Use Offers a Way Forward ............85

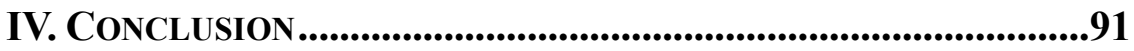

V. APPENDIX: MEMORANDUM FROM ALFRED B. ENGELBERG TO SENATOR CHARLES E. SCHUMER .............................................92 


\section{INTRODUCTION}

Among certain patent lawyers, one number generates some awe and trepidation: 1498. It is the section number of a statute in Title 28 of the United States Code, a law that provides the U.S. government with the power to manufacture and use any patented invention at the cost of "reasonable and entire compensation for such use and manufacture." 1 This seemingly unremarkable statutory language has sat on the books for over a century. Yet 28 U.S.C. $\S 1498$ and government patent use are regularly characterized in the language of extremity. Commentators describe the statute as "breaking" patents, ${ }^{2}$ "seizure" of rights, ${ }^{3}$ "stealing,"4 "expropriating private property," 5 "taboo," "6 "a radical change," 7 a "specter," 8 a

${ }^{1} 28$ U.S.C. $\S 1498$ (a). Other current laws, most notably the march-in rights provision of the Bayh-Dole Act, provide alternate pathways for the government to make use of patented inventions. See 35 U.S.C. § 203(a); see also 16 U.S.C. $\S 831 \mathrm{r}$ (Tennessee Valley Authority power to use patented inventions); 42 U.S.C. $\S 2183$ (b)(2) (Atomic Energy Commission power to use and license patents). See generally Tejas N. Narechania, Patent Conflicts, 103 GEO. L.J. 1483, 1513-16 (2015).

${ }^{2}$ E.g., Daniel R. Cahoy, Breaking Patents, 32 Mich. J. INT’L L. 461, 465 n.15 (2011) (noting use of phrase "for hyperbolic effect").

${ }^{3}$ Michael Lehr, Federal Seizure of Patented Inventions: A COVID-19 Response, DUNLAP BENNETT \& LUDWIG (Apr. 2, 2020), https://www.dbllawyers.com/ federal-seizure-of-patented-inventions-a-covid-19-response; see Chris Katopis, Recognizing the Limits of Government Procurement in the Pharmaceutical Industries, Ctr. FOR ProteCtion InTEll. Prop. (Dec. 20, 2018), https://cpip. gmu.edu/2018/12/20/recognizing-the-limits-of-government-procurement-in-thepharmaceutical-industries.

${ }^{4}$ E.g., Elizabeth Wright, Stealing Patents Won't Bring Down Drug Costs, Citizens Against Gov'T WASTE (Apr. 3, 2018), https://www.cagw.org/ thewastewatcher/stealing-patents-won $\% \mathrm{E} 2 \% 80 \% 99$ t-bring-down-drug-costs; Charles Sauer, Government May Attempt to Steal COVID Vaccine, REALClEAR HEALTH (June 17, 2020), https://www.realclearhealth.com/articles/2020/06/17/ government_may_attempt_to_steal_covid_vaccine_111060.html.

5 James Edwards, A Protection, Not a Weapon, CONSERVATIVES FOR Prop. RTS (May 27, 2020), https://www.property-rts.org/post/a-protection-not-a-weapon.

${ }^{6}$ Natalie Shure, Force Drug Companies to Lower Prices, AM. ProsPeCt (Sept. 26, 2019), https://prospect.org/day-one-agenda/force-drug-companies-to-lowerprices.

${ }^{7}$ Adam Houldsworth, New York Times' Seizure Call Shows How Far the Tide Is Turning Against Pharma IP, IAM (July 13, 2019), https://www.iam-media.com/ law-policy/new-york-times-pharma-patents.

${ }^{8}$ Joel Wallace, Mad Dash to Coronavirus Vaccine May Face Legal Hurdles, 
"nuclear option," 9 and equivalent to eminent-domain condemnation. ${ }^{10}$ Even supporters of invoking the law sometimes characterize use of $\S 1498$ as exceptional. ${ }^{11}$ And the COVID-19 pandemic, despite having elicited numerous calls to invoke

IPWATCHDOG (Mar. 12, 2020), https://www.ipwatchdog.com/2020/03/12/maddash-coronavirus-vaccine-may-face-legal-hurdles/id=119790.

${ }^{9}$ E.g., Michael Rosen, Running Roughshod over Intellectual Property Rights Won't Lower Drug Prices, AEIDEAS BlOG (July 24, 2018), https://www.aei.org/ technology-and-innovation/intellectual-property/running-roughshod-over-

intellectual-property-rights-wont-lower-drug-prices; Valerie Bauman, Government May Have Ownership or Rights to Coronavirus Vaccines, BlOOMBERG L. (Mar. 20, 2020), https://news.bloomberglaw.com/pharma-andlife-sciences/government-may-have-ownership-or-rights-to-coronavirusvaccines.

${ }^{10}$ In addition to the literature that analyzes $\S 1498$ under a takings framework, see infra note 20, there is significant commentary that invokes eminent domain largely for rhetorical effect. See, e.g., Adam Mossoff, Sean O'Connor \& Evan Moore, Proposal for Drug Price Controls is Legally Unprecedented and Threatens Medical Innovation, CTR. FOR PROTECTION INTELL. Prop. (Nov. 5, 2018), https://cpip.gmu.edu/2018/11/05/proposal-for-drug-price-controls-islegally-unprecedented-and-threatens-medical-innovation; Henry Grabowski, Government Appropriation of Breakthrough Drug Patent Rights Would Deter Biopharmaceutical R\&D and Innovation, HeAlth AFF. BLOG (June 20, 2016), https://www.healthaffairs.org/do/10.1377/hblog20160620.055440/full.

${ }^{11}$ See, e.g., Letter from Bernard Sanders, Senator, U.S. Senate, to Robert A. McDonald, Sec'y, U.S. Dep't of Veterans Affairs 1 (May 12, 2015), https://www. sanders.senate.gov/download/051215-letter (calling for Department of Veterans Affairs to use $\S 1498$ "to break the patents" on certain drugs); Joel Dodge, The Government Can Legally Commandeer Drug Patents, PEOPLE's POL'Y PROJECT (Oct. 2, 2017), https://www.peoplespolicyproject.org/2017/10/02/thegovernment-can-legally-commandeer-drug-patents (quoting Sen. Bill Cassidy on use of $\S 1498$ to "commandeer" the drug industry); George Abi Younes et al., COVID-19: Insights from Innovation Economists, 47 SCI. \& PUB. POL'Y 1, 7 (2020) (describing "implementation of compulsory licensing" as "challenging but a real option on the table"); Editorial Bd., How the Government Can Lower Drug Prices, N.Y. TIMES (June 20, 2018), https://www.nytimes.com/2018/06/20/ opinion/prescription-drug-costs-naloxone-opioids.html (describing $§ 1498$ as "a sort of eminent domain"). In their authoritative analysis of $\S 1498$ in the pharmaceutical context, Brennan, Kapczynski, Monahan, and Rizvi advocate use of $\S 1498$ but conclude that the tool should be used relatively sparingly, "suggest[ing] that the government only invoke its $\S 1498$ power where drug pricing has created sizeable deadweight loss." Hannah Brennan et al., $A$ Prescription for Excessive Drug Pricing: Leveraging Government Patent Use for Health, 18 YALE J.L. \& TECH. 275, 319 (2016). The authors also argue that, "[a]s with eminent domain, where the government often purchases land on the private market despite having the power to take it, so too should government use of patents be invoked in the exceptional rather than routine case." Id. 
$\S 1498,{ }^{12}$ has not changed the views of many that government patent use is a destabilizing intervention, tantamount to "throw[ing] our IP system out the window." 13

To be sure, $\S 1498$ can be used in bold, interventionist ways. For example, Senators Bernie Sanders and Elizabeth Warren, along with the New York Times editorial board, have called for the use of $\S 1498$ to discipline the pricing of certain vital and best-selling prescription drugs. ${ }^{14}$ Though the United States has not used $\S 1498$ in this dramatic way, there is much merit to such bold use, which could save billions in public and private drug spending. ${ }^{15}$

${ }^{12}$ See, e.g., Michael Liu et al., March-in Rights and Compulsory LicensingSafety Nets for Access to a COVID-19 Vaccine, Health AfF. Blog (May 6, 2020), https://www.healthaffairs.org/do/10.1377/hblog20200501.798711/full; Amy Kapczynski, Paul Biddinger \& Rochelle Walensky, Remdesivir Could Be in Short Supply. Here's a Fix, N.Y. TIMES (July 29, 2020), https://www.nytimes.com/ 2020/07/28/opinion/remdesivir-shortage-coronavirus.html.

${ }_{13}$ Adam Houldsworth, IP Is Crucial to Finding Breakthrough Covid-19 Medicines, Novartis Policy Head States, IAM (Apr. 30, 2020), https://www.iammedia.com/coronavirus/ip-crucial-finding-breakthrough-covid-19-medicinesnovartis-policy-head-states (quoting Corey Salsberg, Head of IP Affairs at Novartis); see also Tom Giovanetti, Attempts to Degrade Drug Patents are Counterproductive in This Pandemic, TownhaLl (June 1, 2020), https:// townhall.com/columnists/tomgiovanetti/2020/06/01/progressive-activists-wantto-keep-meritless-obama-era-lawsuits-alive-n2569704 (invoking § 1498 during pandemic "is to do away with the IP system for good"); Bauman, supra note 9; Matt Rizzolo et al., What If Gov't Allows Patent Infringement For COVID-19 Drugs?, LAw360 (Apr. 1, 2020), https://www.law360.com/articles/1258739/ what-if-gov-t-allows-patent-infringement-for-covid-19-drugs.

${ }^{14}$ See Sanders, supra note 11; Maia Anderson, EpiPen, Humira Among Drugs Warren Wants to Regulate, BECKER'S HOSP. REV. (Nov. 19, 2019), https://www. beckershospitalreview.com/pharmacy/epipen-humira-among-drugs-warrenwants-to-regulate.html; Editorial Bd., supra note 11; see also Letter from Ro Khanna, Member of Cong., House of Representatives, to Alex Azar, Sec'y, U.S. Dep't of Health \& Human Servs. (Feb. 15, 2018), https://khanna.house.gov/sites/ khanna.house.gov/files/Final\%20Letter\%20-\%20signed.pdf.

${ }^{15}$ See, e.g., Christopher J. Brennan et al., supra note 11, at 280-81; Brittany S. Bruns, The Pharmaceutical Access Act: An Administrative Eminent Domain Solution to High Drug Prices, 106 CAL. L. REV. 2023, 2047-54 (2018); Amy Kapczynski \& Aaron S. Kesselheim, "Government Patent Use": A Legal Approach to Reducing Drug Spending, 35 Health AfF. 791, 792-93 (2016); Barbara M. McGarey \& Annette C. Levey, Patents, Products, and Public Health: An Analysis of the CellPro March-in Petition, 14 BERKELEY TECH. L.J. 1095, 1115 (1999) (noting advantages of $\S 1498$ over Bayh-Dole Act march-in rights); Christopher J. Morten \& Amy Kapczynski, Assessing Drug Pricing Reform 
But the statute is not limited to such uses, and our focus in this Article is to show that $\S 1498$ need not be at all extreme in its operation or impact. Under its authority to have patented inventions "used or manufactured by or for the United States" at the cost of "reasonable and entire compensation," the government can fine-tune the scope and duration of its invocation of $\S 1498$ to make modest interventions in the market, perhaps with only limited disruption to investment-backed expectations. And as a matter of history, $\S 1498$ is not nearly as exceptional as some modern critics make it out to be. The government has long exercised both $\S 1498$ and even stronger government patent-use powers, often with substantial support from the stakeholder community.

To highlight this more modest, ordinary role that $\S 1498$ can play in national policy, we consider a specific class of uses: federal responses to complex large-scale crises, including the COVID-19 pandemic that the world faces today. While the statute's effectiveness can go well beyond crisis management, a focus on emergency contexts reveals particular aspects and advantages of $\S 1498$ that illuminate its value and carry over into non-emergency contexts as well. To be sure, national emergencies entail some policy considerations different from those of non-emergency times, but nevertheless they helpfully draw focus to latent features of $\S 1498$ that might otherwise escape attention. We find that $\S 1498$ is well suited to a perfectly ordinary role as a crisis management policy tool, on the same plane as other emergency powers such as the Defense Production Act, the invocation of which many have supported to tackle COVID-19. ${ }^{16}$

Proposals: The Real Leverage and Benefits of Competitive Licensing, HEALTH AfF. BLOG (Nov. 4, 2019), https://www.healthaffairs.org/do/10.1377/ hblog20191101.594551/full (noting unique benefits of compulsory licensing of patents on prescription drugs); Alex Wang \& Aaron S. Kesselheim, Government Patent Use to Address the Rising Cost of Naloxone: 28 U.S.C. $\$ 1498$ and Evzio, 46 J.L. MED. \& ETHICS 472 (2018).

16 See, e.g., Tim Hains, Nancy Pelosi: President Trump Must Use Defense Production Act to Build More Ventilators Now, "Save Lives," REALCLEAR POL. (Mar. 31, 2020), https://www.realclearpolitics.com/video/2020/03/31/pelosi_ trump_must_use_defense_production_act_to_build_more_ventilators_now.html; Caleb Watney \& Alec Stapp, Masks for All: Using Purchase Guarantees and Targeted Deregulation to Boost Production of Essential Medical Equipment, MERCATUS CTR. 3-5 (Apr. 8, 2020), https:/www.mercatus.org/publications/ covid-19-crisis-response/masks-all-using-purchase-guarantees-and-targetedderegulation. 
This Article is, to our knowledge, the first to consider in detail the special role of government patent use in cases of national emergency in the United States. ${ }^{17}$ Past scholarship on the historical development and use of $\S 1498$ has tended to focus on judicial cases where patents were actually used by the U.S. government under the statute or its predecessors, ${ }^{18}$ which are useful for explicating the scope and nature of the statute but less helpful for assessing the appropriateness of invoking it in the first place (since, after all, a case about government patent use can only arise after the government has used the patent). A handful discuss its legislative history and note in passing its connection to American involvement in World War I. ${ }^{19}$ Turning to normative analyses, substantial

${ }^{17}$ While this Article does not treat international or foreign law extensively, we note that $\S 1498$ is related to and consistent with international treaty provisions and other nations' laws that permit for compulsory licensing "in the case of a national emergency or other circumstances of extreme urgency or in cases of public non-commercial use." See Agreement on Trade-Related Aspects of Intellectual Property Rights, Apr. 15, 1994, Marrakesh Agreement Establishing the World Trade Organization, Annex 1C, art. 31(b), 1869 U.N.T.S. 299; Coenraad Visser, Patent Exceptions and Limitations in the Health Context, U.N. Doc. SCP/15/3 (Sept. 2, 2010). For discussion of the international dimensions of government patent use in emergency situations, see Reed Beall \& Randall Kuhn, Trends in Compulsory Licensing of Pharmaceuticals Since the Doha Declaration: A Database Analysis, PLoS MED., 2012, at 3; Cynthia M. Ho, Inoculation Inventions: The Interplay of Infringement and Immunity in the Development of Biodefense Vaccines, 8 J. HEALTH CARE L. \& POL'Y 111, 151 (2005); Robert Shapiro, Patent Infringement During a Time of National Emergency: Are Canadian, American and Mexican Governments Permitted to Do So Under Their Domestic Law, NAFTA and TRIPS; If So at What Cost?, 18 WINDSOR REV. LEGAL \& SoC. ISSUES 37, 44-56 (2004); and Sapna Kumar, Compulsory Licensing of Patents During the Pandemic (Dec. 11, 2020) (unpublished manuscript), https:// ssrn.com/abstract $=3636456$.

${ }^{18}$ See, e.g., James E. Denny, Eminent Domain Aspects of 28 USC 1498, 4 PAT. TRAdEMARK \& COPYRIGHT J. RES. \& EduC. 257, 257-74 (1960); Lionel M. Lavenue, Patent Infringement Against the United States and Government Contractors Under 28 U.S.C. $\$ 1498$ in the United States Court of Federal Claims, 2 J. InTEll. Prop. L. 389, 408-15 (1995); Richard J. McNeely, Governmental Indirect Patent Infringement: The Need to Hold Uncle Sam Accountable Under 28 U.S.C $\$ 1498,36$ CAP. U. L. REV. 1065, 1100-05, 111218 (2007); Blake E. Reese, Note, Do as I Say, Not as I Do: An International and Comparative Study of Governments' Rights to "Infringe" Patents in Light of the Federal Circuit's Recent Interpretation of 28 U.S.C. $\$ 1498$ and a Call for Congress to Modernize the Statute, 4 BuFF. InTELL. PROP. L.J. 84, 86-102 (2006).

${ }^{19}$ See Colleen V. Chien, Cheap Drugs at What Price to Innovation: Does the 
literature addresses the question of whether government patent use under $\S 1498$ constitutes a Fifth Amendment taking of property, ${ }^{20}$ a proposition that the Federal Circuit recently rejected. ${ }^{21}$ That literature does not generally distinguish emergency conditions from other situations. ${ }^{22}$ Others have considered the role of $\S 1498$ in

Compulsory Licensing of Pharmaceuticals Hurt Innovation?, 18 BERKELEY TECH. L.J. 853, 868 (2003) ("[T] he statute was originally conceived with wartime urgency in mind"); Sean M. O'Connor, Taking, Tort, or Crown Right? The Confused Early History of Government Patent Policy, 12 J. MARShall ReV. INTELL. Prop. L. 145, 188 (2012); William Brownell Humphrey, A History and Analysis of Section 1498 of Title 28 of the United States Code Dealing with Unlicensed Use of Patents by the United States Government and Its Effect on Procurement 9-12 (1974) (unpublished thesis), https://apps.dtic.mil/sti/pdfs/ AD0777985.pdf. Brennan and colleagues give a "brief" history of $\S 1498$ 's application that is more extensive than most, though they consider use of the statute broadly rather than its specific application to national emergencies. See Brennan et al., supra note 11, at 298-307.

${ }^{20}$ For analysis contending that it is, see, for example, Joshua I. Miller, 28 U.S.C. $\S 1498$ (a) and the Unconstitutional Taking of Patents, 13 YALE J.L. \& TECH. 1, 5 (2011) (arguing that, being an act of eminent domain, exercise of $\S 1498$ requires compensation for litigation costs); Lavenue, supra note 18, at 506 (similar); David R. Lipson, We're Not Under Title 35 Anymore: Patent Litigation Against the United States Under 28 U.S.C. $\$ 1498$ (a), 33 PuB. ConT. L.J. 243, 244-45 (2003). For contrary views, see, for example, Denny, supra note 18, at 274 (finding eminent-domain treatment of $\S 1498$ to be "unfortunate in the many problems that have arisen" in the case law as a result); Jonathan S. Masur \& Adam K. Mortara, Patents, Property, and Prospectivity, 71 Stan. L. Rev. 963, 991-92 (2019) (observing that government patent use "is described in terms of eminent domain or takings when that characterization is irrelevant to the resolution of the case at hand"). Much of this commentary was prompted by a Federal Circuit panel decision in Zoltek Corp. v. United States (Zoltek I) that government patent use was not a Fifth Amendment taking. See 442 F.3d 1345, 1353 (Fed. Cir. 2006) (per curiam), vacated, 672 F.3d 1309 (Fed. Cir. 2012) (en banc); Bradley M. Taub, Why Bother Calling Patents Property-The Government's Path to License Any Patent and Maybe Pay for It, 6 J. MARshall ReV. InTELl. Prop. L. 151, 154 (2006); Justin Torres, The Government Giveth, and the Government Taketh Away: Patents, Takings, and 28 U.S.C. § 1498, 63 N.Y.U. ANN. SuRV. AM. L. 315, 33841 (2007); Reese, supra note 18, at 117-19. That decision was vacated when an en banc court reversed the panel on different grounds. See Zoltek Corp. v. United States (Zoltek II), 672 F.3d at 1318 (vacating Zoltek I); id. at 1327 ("[W]e need not and do not reach the issue of the Government's possible liability under the Constitution for a taking.").

${ }^{21}$ See Golden v. United States, 955 F.3d 981, 988 (Fed. Cir. 2020); see also infra notes 213-212-220.

${ }^{22}$ Earlier commentary from about the 1960 s, by contrast, does occasionally note 
specific fields such as health care, ${ }^{23}$ government contracting and procurement, ${ }^{24}$ and human rights. ${ }^{25}$

Commentators have, to be sure, considered the applicability of $\S 1498$ to certain specific emergency contexts. ${ }^{26}$ Several commentators have suggested that $\S 1498$ may be useful in a public health emergency, for example. ${ }^{27}$ Some have specifically supported government patent use as a relief measure during the COVID-19 pandemic. ${ }^{28}$ Others have noted the statute's relationship to war, generally in service of concluding its use is inappropriate outside of

this distinction, perhaps because the active area of discussion at that time was the role of $\S 1498$ in government procurement. See, e.g., Humphrey, supra note 19, at 21 .

${ }^{23}$ See references cited supra note 15.

${ }^{24}$ See, e.g., Humphrey, supra note 19, at 14-20; Lavenue, supra note 18, at 48387; Gerald J. Mossinghoff \& Robert F. Allnutt, Patent Infringement in Government Procurement: A Remedy Without a Right, 42 Notre DAME L. REV. 5, 9-14 (1967).

${ }^{25}$ See Cahoy, supra note 2, at 501-07.

${ }^{26}$ See, e.g., Daniel R. Cahoy, Treating the Legal Side Effects of Cipro: A Reevaluation of Compensation Rules for Government Takings of Patent Rights, 40 AM. BUS. L.J. 125, 136 (2002) (rejecting "blanket arguments" against § 1498); see also Grace K. Avedissian, Global Implications of a Potential U.S. Policy Shift Toward Compulsory Licensing of Medical Inventions in a New Era of "SuperTerrorism," 18 AM. U. INT'L L. REV. 237, 291 (2002) (calling for compulsory licensing to respond to "super-terrorism"). Torrance provides a comprehensive review of patent-related options, including $\S 1498$, during a natural disaster, but focuses on a new statutory proposal. See Andrew W. Torrance, Patents to the Rescue-Disasters and Patent Law, 10 DePaul J. Health Care L. 309, 354 (2007).

${ }^{27}$ See, e.g., Dennis D. Crouch, Nil: The Value of Patents in a Major Crisis Such as an Influenza Pandemic, 39 Seton Hall L. ReV. 1125, 1126 (2009); McGarey \& Levey, supra note 15, at 1115 (briefly noting speed advantages of $\S 1498$ in cases of "a public health need for the invention, particularly an immediate need"); Neiloy Sircar, Public Health Emergencies: Reconciling Trips and IHR (2005), 41 Hous. J. INT'L L. SidEBAR 101, 120 (2018); cf. Amanda Mitchell, Tamiflu, the Takings Clause, and Compulsory Licenses: An Exploration of the Government's Options for Accessing Medical Patents, 95 CAL. L. REv. 535, 557-58 (2007) (favoring condemnation of patents over $\S 1498$ during an influenza epidemic). One article considers several advantages and drawbacks of government patent use during an emergency, but ultimately reaches no conclusion and recommends that governments "continue to use their negotiating skills in hopes of securing agreements" with patent holders. Shapiro, supra note 17, at 62.

${ }^{28}$ See Kumar, supra note 17, at 27-30; sources cited supra note 12. 
wartime. ${ }^{29}$ But this research generally stops at observing that $\S 1498$ could remediate (or not remediate) particular situations, without developing a more comprehensive theoretical basis for when and why the government should make use of third-party patents during national emergencies. And some scholars, ${ }^{30}$ including Hemel and Ouellette, ${ }^{31}$ have advocated for an alternative approach to expanding access to patented anti-COVID-19 technologies - patent buyouts of some sort-without (to our knowledge) weighing the advantages and disadvantages of a buyout against those of government patent use under $\S 1498$.

This Article thus makes several contributions. First, it provides an up-to-date primer on government patent use-what it is, how it works, and how it compares to other policy tools to incentivize new inventions and allocate access to those inventions. ${ }^{32}$ Second, it makes a novel descriptive contribution by synthesizing the history

${ }^{29}$ See, e.g., Taub, supra note 20, at 171-72; Humphrey, supra note 19, at 21 (quoting speech by Leonard Rawicz, Patent Counsel, Goddard Space Flight Center) ("[S]ome view that the purpose of 28 U.S.C. 1498 was to assure patent litigation free procurement only during a national emergency or war...."); Trojan, Inc. v. Shat-R-Shield, Inc., 885 F.2d 854, 858 (Fed. Cir. 1989) (Newman, J., concurring).

30 See, e.g., Anton Howes, Bringing the Future Forward, ENTREPRENEURS NETWORK (May 27, 2020), https://www.tenentrepreneurs.org/blog/bringing-thefuture-forward; Anton Howes, Innovation: Eyes on the Prize, ENTREPRENEURS NETWORK (Mar. 26, 2020), https://www.tenentrepreneurs.org/blog/innovationeyes-on-the-prize; Thomas Pogge \& Peggy Tse, Restructuring Pharmaceutical Innovation, CHINA GLOBAL TELEVISION NETWORK (June 2, 2020), https://news. cgtn.com/news/2020-06-02/Restructuring-pharmaceutical-innovation-QZq50NZ Oxi/index.html.

${ }^{31}$ See Daniel Hemel \& Lisa Ouellette, Pharmaceutical Profits and Public Health Are Not Incompatible, N.Y. TIMES (Apr. 8, 2020), https://www.nytimes.com/ 2020/04/08/opinion/coronavirus-drug-company-profits.html.

${ }^{32}$ Others have covered large portions of this descriptive terrain before us, though we see value in explaining the basics, particularly as a Cabinet Secretary professed ignorance of $\S 1498$ just last year (despite writing about the law in 2002). See Ari Shapiro \& Selena Simmons-Duffin, How HHS Secretary Reconciles Proposed Medicaid Cuts, Stopping the Spread of HIV, NPR (Apr. 8, 2019), https://www. npr.org/sections/health-shots/2019/04/08/711020181/how-trumps-hhs-

reconciles-medicaid-cuts-with-stopping-the-spread-of-hiv (quoting Secretary Alex Azar as stating that "There's no such thing as a legal right to break patents in the United States.”). But see Alex Azar II, Cipro: Good Deal, Good Policy, AM. LAW., Apr. 2002, at 141 ("Section 1498(a) permits the United States to procure items without first obtaining a license, so long as it pays reasonable and entire compensation."). 
of the use of $\S 1498$ and related statutes in times of national emergency. We include numerous early examples of government patent use that have not been explored in the legal academic literature. Even though the law has never been limited to those contexts and has broader application, § 1498 and norms of government patent use were shaped by national emergencies like the two world wars, and government patent use was widely accepted to be a valuable and critical tool during such emergencies. Third, the Article makes a novel, general normative case for government patent use in national emergencies, based on four key features of $\S$ 1498: (1) speed, (2) flexibility, (3) ex post determination of the appropriate compensation and (4) determination of that compensation by an impartial adjudicator. Whenever these four features are advantageous - which will be true in most national emergency situations, as we show, but may also apply in peacetime - the U.S. government should strongly consider government patent use over patent buyouts and other policy tools. Government patent use under $\S 1498$ can be used in many ways, big and small, in a national emergency. Fourth, we provide a novel roadmap to government patent use in one particularly practical use case: ensuring adequate and affordable access to remdesivir, an antiviral drug, in the COVID-19 pandemic.

While the focus of this Article is the utility of $\S 1498$ in the context of a national crisis, government patent use does not need to be reserved for extraordinary circumstances. We aim to demonstrate that government patent use is a flexible, highly useful policy tool. As we show below, $\S 1498$ can be used modestly as well as massively to achieve various public benefits-lowering prices, expanding supply, or shielding socially useful activity from the risk of liability or injunction. The four key features of $\S 1498$ that we highlight are permanent features of the section, and their benefits may warrant government patent use in ordinary circumstances as well as extraordinary ones, and not just in times of crisis but in times of relative calm, too. Ultimately, $\S 1498$ is as much a Swiss Army knife as a sledgehammer.

The Article proceeds as follows. Part I reviews the historical development of $\S 1498$ and government patent use, particularly from a legislative and policy perspective, to assess perceptions and legislative expansions of the role of government patent use during times of national emergency. Part II briefly describes the presentday nature of $\S 1498$ and places it in the context of other policy tools 
relevant to technological development and national crisis management. Part III then identifies several key advantages of $\S 1498$ that are especially pertinent to large-scale crisis situations. Those advantages can be used as factors to assess the utility of $\S 1498$ in particular situations, which we demonstrate through a case study of government patent use to expand supply and access to the COVID-19 treatment remdesivir. Part IV briefly concludes.

\section{Historical Role of Government Patent Use IN} TIMES OF CRISIS

Throughout history, $\S 1498$ has been closely tied to American responses to national crises. In addition to reviewing the origins of $\S 1498$, the discussion below focuses on three examples: the First World War, the Second World War, and the bioterrorism threat following September 11, 2001.

While the U.S. government used $\S 1498$ extensively at these times and others, ${ }^{33}$ the purpose of this Part is not to catalog invocations of $\S 1498$. Instead, to discern the policy considerations that motivate the legislative and executive branches to contemplate government patent use, we focus on the complex and disputed cases, namely situations where policymakers relied on powers broader than $\S 1498$, amended $\S 1498$, or publicly contested the application of that statute. Aside from there being better records of these disputed cases, ${ }^{34}$ the arguments elicited best highlight lawmakers' interests and motivations in ways that are instructive for future situations of government patent use.

\section{A. Origin of the Statute}

Enacted in 1910, the first incarnation of $\S 1498^{35}$ was not born of any national emergency - it was triggered by Congress repaving the Capitol building. In Schillinger v. United States, the owner of a patent on a concrete pavement method brought an infringement suit

${ }^{33}$ For articles reviewing cases under and invocations of $\S 1498$, see generally Brennan et al., supra note 11, at 302-07; Denny, supra note 18, at 258-74; Lavenue, supra note 18, at 452-72.

34 Because there is no formal process for invoking $\S 1498$, see infra text accompanying note 230 , uses of the statute are not catalogued and may even go unrecorded.

35 See Act of June 25, 1910 (1910 Act), ch. 423, 36 STAT. 851. The law was not numbered " $\$ 1498$ " at the time, but the government patent use laws described herein share a direct lineage to contemporary $\S 1498$. See $\S 1498$, hist. n. (noting derivation from 35 U.S.C. $\S 68$ (1940)); 35 U.S.C. $\S 68$ (noting derivation from 1910 Act). Accordingly for purposes of simplicity, this Article uses that section number to refer to the statute throughout. 
against the government, whose contractor had used the patented method during the Capitol renovation. ${ }^{36}$ The Supreme Court rejected the suit on grounds of sovereign immunity. ${ }^{37}$ Despite the Tucker Act having partially waived sovereign immunity for "claims founded upon the Constitution ... or upon any contract" with the United States, ${ }^{38}$ the Court found this waiver inapplicable. The contract provision did not apply because the patent infringement action was "one sounding in tort." 39 Nor was the action "founded upon the Constitution" despite the patent holder's protestations that the government's infringement was a "taking of private property," as the Court deemed that reading excessively broad; ${ }^{40}$ instead the Court read the waiver of sovereign immunity for Constitutionfounded claims to exclude torts. ${ }^{41}$

In response to Schillinger, Congress enacted the Act of June 25, 1910 to "provide additional protection for owners of patents" by offering them a cause of action for "reasonable compensation" (but not injunctive relief) for any use of a patented invention "by the United States without license of the owner thereof or lawful right to use the same." 42 Contrary to how some have viewed the law, then, the logic of $\S 1498$ 's predecessor statute was not that it cut back on patentees' remedies against the government; the baseline situation was that no remedy was available at all in view of sovereign immunity, and $\S 1498$ 's predecessor expanded patent protection by offering a new, albeit partial, remedy for government use. ${ }^{43}$

36155 U.S. 163, 171-72 (1894).

37 See id. at 167 ("The general principle which we have already stated as applicable to all governments, forbids, on a policy imposed by necessity, that they should hold themselves liable for unauthorized wrongs inflicted by their officers on the citizen, though occurring while engaged in the discharge of official duties.") (quoting Gibbons v. United States, 75 U.S. (8 Wall.) 269, 275 (1869)).

${ }^{38}$ Tucker Act, ch. 359, sec. 1, 24 STAT. 505, 505 (1887), quoted in Schillinger, 155 U.S. at 167.

${ }^{39}$ Schillinger, 155 U.S. at 169.

${ }^{40} \mathrm{Id}$. at 168 ("Can it be that Congress intended that every wrongful arrest and detention of an individual, or seizure of his property by an officer of the government, should expose it to an action for damages in the Court of Claims?"). ${ }^{41} I d$. ("[Congress] added, 'all claims founded upon the Constitution of the United States,' but that does not include claims founded upon torts ....").

${ }^{42}$ Act of June 25, 1910 (1910 Act), ch. 423, 36 STAT. 851.

${ }^{43}$ See Brennan et al., supra note 11, at 298-99; see also ADDITIONAL Protection FOR OWNERS OF PATENTS, H.R. REP. NO. 61-1288, at 3 (1910) (“Our only purpose is to extend the jurisdiction of [the Court of Claims] so that it may entertain suits 
While national emergencies did not cause $\S 1498$ 's original enactment, at least some members of Congress recognized the law's close tie to one sort of emergency condition: national security. The House report "conceded that the Government ought to have the right to appropriate any invention necessary or convenient for natural defense or for beneficent public use, and that, too, without previous arrangement or negotiation with the owner." 44 The congressional debate record also reveals that Congress consulted with the War and Navy Departments on the bill, and Representative Currier, the leading proponent of the 1910 Act in the House, specifically called out during the debate the possibility that "government officers can be restrained in preparing the national defense." ${ }^{45}$ In subsequent debate, Representative Dalzell, another proponent of the bill, was asked what should happen if "one of our officers of the army or the navy, having invented some useful implement of war, should decline to allow the Government to have it." Dalzell's answer was that the invention "ought to be appropriated by the Government by due process of law." 46 Thus, $\S 1498$ in its origins was plainly envisioned to have applicability outside of national emergencies - repaving the Capitol was rather clearly not one-but the statute's authors recognized its relevance to emergency conditions from the very beginning.

\section{B. World War I}

Hypothetical national security and emergency response concerns became reality during the First World War. As a war that heavily exploited science in the service of combat and that arguably invented the military public-private partnership, ${ }^{47}$ World War I set

and award compensation to the owners of patents ...."). One might wonder whether the statutory language "without . . lawful right to use" in the 1910 Act undercuts this view of $\S 1498$ as expanding conditions on the patent grant, the argument being that if the government has a preexisting right to use a patent, then the statute could not logically refer to situations where the government is "without . . lawful right to use" the patent. But the legislative history makes clear that the aforementioned provision was intended to refer to a different form of "lawful right to use," namely shop rights arising from inventions of government employees. See H.R. REP. No. 61-1288, supra, at 3.

${ }^{44}$ H.R. REP. NO. 61-1288, supra note 43, at 2. The term "natural defense" is likely a typographical error; it probably should have been "national defense."

4545 CONG. REC. 8759 (1910).

${ }^{46} I d$. at 8781 (1910).

${ }^{47}$ See M. Anthony Mills \& Mark P. Mills, The Invention of the War Machine, 42 
the stage for clashes between patents and national defense, clashes that would sharpen the role of government patent use in times of crisis. While patent disputes interfered with the war effort with respect to multiple technologies, ${ }^{48}$ the development of aviation technology most clearly characterizes the role of government patent use during war.

The Wright brothers' solution to the lateral-roll problem in 1903 gave birth to a worldwide industry of powered aircraft. ${ }^{49}$ It also gave birth to a massive tangle of patent litigation, as the Wrights' main competitor, airplane manufacturer Glenn Curtiss, sought to avoid the Wrights' patented twisting-wing design through a design-around involving inflexible hinged ailerons. ${ }^{50}$ Across the early 1900s, the brothers waged a forceful campaign of patent lawsuits against not just Curtiss and other manufacturers but also individual aviators at flying exhibitions, reportedly springing service on them immediately after the shows. ${ }^{51}$ And both Curtiss and the Wrights engaged in patent licensing at rates that some historians have

New Atlantis 3, 3 (2014); see also Katherine C. Epstein, Torpedo: INVENTING THE MiLITARY-INDUSTRIAL COMPLEX IN THE UNITED STATES AND GREAT BRITAIN 2-3 (2014) (describing role of torpedoes "in the invention of the military-industrial complex").

${ }^{48}$ Disputes over torpedo technology, for example, would drag the government through almost a decade of litigation and arguably stall American torpedo development. See E.W. Bliss Co. v. United States, 253 U.S. 187, 188-90 (1920); EPSTEIN, supra note 48, at 154; Charles Duan, Of Monopolies and Monocultures: The Intersection of Patents and National Security, 36 SANTA ClaRA High TeCH. L.J. 369, 388-89 (2020). The Chief of the Navy's Bureau of Ordnance wrote that its torpedo contractor, the E.W. Bliss Company, had used its patent-backed "monopoly" to force the government "to accept the terms offered or get no torpedoes," which ultimately "influenced the E.W. Bliss Company in its prices, deliveries and workmanship." Letter from N.E. Mason, Chief of Bureau of Ordnance, to Sec'y of the Navy, in Estimates Submitted by the Secretary of the Navy: Hearing Before the H. Comm. on Naval Affairs, 59th Cong. 433, 436 (1907), https://www.loc.gov/item/tmp92007441.

${ }^{49}$ See U.S. Patent No. 821,393 3 11. 12-30 (filed Mar. 23, 1903); see also Wright Co. v. Herring-Curtiss Co., 177 F. 257, 259 (C.C.W.D.N.Y. 1910) (noting Wrights' successful demonstrations), rev'd, 180 F. 110 (C.C.A.2d 1910).

${ }^{50}$ See Wright, 177 F. at 259-60; Herbert A. Johnson, The Wright Patent Wars and Early American Aviation, 69 J. AIR L. \& COM. 21, 28-30 (2004) .

${ }^{51}$ See Johnson, supra note 50, at 31-33 \& note 39 (noting "resentment that the Wright Company allowed flying events to occur, and decided whether to sue after the exhibition had been staged"). 
described as "almost confiscatory" and "prohibitive." 52

The Wrights' vigorous patent enforcement is generally considered to have been a key impediment to aviation technology innovation in the United States. ${ }^{53}$ By 1910, Europe had outstripped the United States in airplane motor design, and had made great strides in fixed single-wing aircraft while American manufacturers remained fixated on the Wrights' flexible two-wing configuration. In 1913, on the eve of World War I, the United States was far behind other nations in military aviation: France held 266 military airplanes while the United States sported just six. ${ }^{54}$

With looming war and an industry impasse, the government's military branches found it necessary to take action. Congress in 1915 had formed a National Advisory Committee on Aeronautics, ${ }^{55}$ and in January 1917, Acting Secretary of the Navy Franklin D. Roosevelt and Acting Secretary of War W.M. Ingraham asked

${ }^{52}$ LaWrence Goldstone, Birdmen: The Wright Brothers, Glenn Curtiss, and the Battle to Control the Skies 203 (2014); 1 Alex Roland, Model RESEARCH: THE NATIONAL ADVISORY COMMITTEE FOR AERONAUTICS 19151958, at 38 (1985).

${ }^{53}$ There is some debate as to the relationship between the Wrights' patent activity and American innovation lag. The conventional view is that American firms eschewed investment in airplane technology out of fear of lawsuits or excessive royalty demands. See, e.g., RolAND, supra note 52, at 38; Phaedra Hise, How The Wright Brothers Blew It, FORBES (Nov. 19, 2003), https://www.forbes.com/2003/ 11/19/1119aviation.html; Johnson, supra note 50, at 42-43; Scott McCartney, Wright Brothers' Patent Battle Proved Costly in Aviation Race, WALL ST. J. (Dec. 17, 2003), https://www.wsj.com/articles/SB107159573141697200; Robert P. Merges \& Richard R. Nelson, On the Complex Economics of Patent Scope, 90 COLUM. L. REV. 839, 890-91 (1990). But several dissenting scholars note that there was substantial investment in airplane manufacturing during the pendency of the lawsuits and immediately after. See Tom D. Crouch, Blaming Wilbur and Orville: The Wright Patent Suits and the Growth of American Aeronautics, in Atmospheric Flight IN THE Twentieth CEnTURY 290-91 (Peter Galison \& Alex Roland eds., 2000); Ron D. Katznelson \& John Howells, The Myth of the Early Aviation Patent Hold-up-How a US Government Monopsony Commandeered Pioneer Airplane Patents, 24 Indus. \& CORP. ChANGE 1, 11 (2014). A potentially better explanation, as one of us has hypothesized elsewhere, is that the Wrights' litigation campaign, especially against foreign aviators, dampened knowledge crossovers between the United States and Europe. See Duan, supra note 48, at 391-92.

${ }^{54}$ See Tom D. Crouch, Wings: A History of Aviation from Kites to the SPACE AGE 147 (2003).

${ }^{55}$ See ROLAND, supra note 52, at 24. 
NACA for a solution to the patent dilemma. ${ }^{56}$ In response, the committee's chairman Charles D. Walcott petitioned President Wilson in February to introduce legislation to appropriate \$1 million for acquiring aviation patents "by purchase, condemnation, donation, or otherwise." The legislation was enacted in a naval appropriations bill on March 4, 1917. ${ }^{57}$

The ability to obtain patents by "condemnation"- that is, seizure by eminent domain — was enough to bring the Wright-Martin and Curtiss-Burgess companies into a cross-licensing agreement. ${ }^{58}$ Under the supervision of NACA and military representatives, the aircraft manufacturers formed the Manufacturers' Aircraft Association and agreed to pay the MAA a royalty of $\$ 200$ per airplane-substantially less than Wright-Martin's usual $\$ 1000$ rate - to be distributed among the patent holders according to set percentages. ${ }^{59}$ Even so, the War and Navy Departments found the \$200 royalty rate infeasible given the government's expected wartime needs for airplane manufacturing, and threatened "to proceed to condemn the necessary patents" unless the MAA reduced the royalty rates to $\$ 100$ per plane, with a maximum payment of $\$ 2$ million. ${ }^{60}$ The MAA agreed, granting in March 1918 the government the requested royalty "during the period of the present war." 61

To be sure, the aviation patent arrangement is not necessarily a model for future actions: Outright condemnation of patents is far stronger than use under $\S 1498,{ }^{62}$ and the MAA, which would outlive World War I by almost a half century, came to be the sort of patent-backed industry cartel that antitrust reformers of the late 1930s would come to criticize strongly. ${ }^{63}$ But the airplane patent wars show how patents can cause problematic unpreparedness in the face of a national crisis such as war, and the origins of the MAA show the government's once-unhesitating willingness to invoke the

56 See id. at 38.

57 See Naval Service Appropriations Act, ch. 180, 39 STAT. 1168, 1169 (1917);

ROLAND, supra note 52, at 39.

${ }^{58}$ See RoLAND, supra note 52, at 39-41; Johnson, supra note 50, at 57.

${ }^{59}$ See Mfrs. Aircraft Ass'n, Inc. v. United States, 77 Ct. Cl. 481, 487 (1933);

Johnson, supra note 50, at 57.

${ }^{60}$ Mfrs. Aircraft Ass'n, 77 Ct. Cl. at 491.

${ }^{61} \mathrm{Id}$. at 492.

${ }^{62}$ See discussion infra notes 216-218 and accompanying text.

${ }^{63}$ See Johnson, supra note 50, at 58-61. 
power of government patent use to bargain for satisfactory licensing arrangements in times of crisis.

Coming off of its successes dealing with aviation patents, the Navy Department next looked to expand government patent use more broadly. In April 1918, Navy Secretary Roosevelt wrote to Congress proposing an expansion of the government patent use statute then in force. ${ }^{64}$ The occasion for Roosevelt's letter was the Supreme Court's decision in William Cramp \& Sons Ship \& Engine Building Co. v. International Curtis Marine Turbine Co. a month earlier, which held that despite the 1910 Act, a government contractor could be sued and enjoined for patent infringement. ${ }^{65}$ Reasoning that the 1910 Act was intended "not to weaken the rights of patentees, but to further secure them," the Court concluded that the statute could not have acted to eliminate suits against government contractors. ${ }^{66}$ The Navy, according to Roosevelt, had been working on the opposite assumption that contractors were insulated from suit, and the Court's decision apparently was now deterring contractors from working with the government. ${ }^{67}$

Roosevelt's proposed amendment to the 1910 Act was introduced in a Senate amendment to the House naval appropriations bill on May 22, 1918. ${ }^{68}$ The amendment was brought to the House floor by Representative Lemuel P. Padgett, chair of the House Committee on Naval Affairs, on June $18 .{ }^{69}$ Padgett initially expressed "great reluctance" about bringing a patent law

${ }^{64}$ See Letter from Franklin D. Roosevelt, Acting Sec'y of the Navy, to Benjamin R. Tillman, Chairman, Senate Comm. on Naval Affairs, in Wood v. Atl. Gulf \& Pac. Co., 296 F. 718, 720, 720 (S.D. Ala. 1924).

${ }^{65}$ See 246 U.S. 28, 42 (1918) (finding "want of foundation for the contention that ... the statute conferred upon all who contracted with the United States for the performance of work a right to disregard and take without compensation the property of patentees").

${ }^{66} \mathrm{Id}$. at 37.

${ }^{67}$ See Roosevelt, supra note 64, at 721. The Navy's justification was that it had relied a prior case, Crozier v. Fried. Krupp AG, 224 U.S. 290 (1912), for the proposition that the 1910 Act insulated government contractors from suit. See Roosevelt, supra note 64, at 721. While Crozier involved infringement by a federal officer, the Court reasoned that the statute applied because "the United States shall be considered as having ratified the act of the officer and be treated as responsible pecuniarily for the consequences." Crozier, 224 U.S. at 305. It appears that the Navy assumed (apparently wrongly, in light of Cramp) that this ratification logic would apply to contractors as well.

6856 CONG. REC. 6886 (1918).

${ }^{69} \mathrm{Id}$. at 7960 . 
amendment to a naval appropriations bill but defended its placement based on the Navy's need for the amendment. ${ }^{70}$ A colleague quickly allayed his concerns:

Mr. [William E.] Cox. Does not the gentleman feel

that this is a law that would expedite the

manufacture of war material?

Mr. Padgett. That is what I am going to do.

Mr. Cox. I think the gentleman could get it in three minutes. $^{71}$

As Cox predicted, the amendment was agreed to, and enacted into law on July $1 .{ }^{72}$

The 1918 amendment effected a recognition of government patent use not just as a compensatory mechanism for patent holders but also as a shield enabling the government to protect certain patent users from injunctions and liability for patent infringement. That such an amendment could pass "in three minutes" when it would "expedite the manufacture of war material" shows that, at least in emergency circumstances such as war, there was no objection to the government limiting patent liability in the service of the public.

\section{World War II}

Government patent use would arise forcefully again at the start of the Second World War. Here as well the historical events show the unique relevance that the government use statute can play at a time of national emergency. In particular, the start of American entry into the war highlighted the immediacy and unpredictability of needs with respect to patents - immediacy and unpredictability that made $\S 1498$ especially well-suited.

To see how the national emergency of a world war invited government patent use, we begin with the pre-war conversation over patents, which was closely tied to the conversation over competition policy. Beginning in the late 1930s, concerns arose over dominant firms and the role of antitrust law in policing oligopoly collusion. ${ }^{73}$

\footnotetext{
${ }^{70}$ See id. at 7961.

${ }^{71} \mathrm{Id}$.

72 See id.; Naval Service Appropriations Act, ch. 114, 40 STAT. 704, 705 (1918).

${ }^{73}$ President Roosevelt's 1938 anti-monopoly speech to Congress is generally considered to signal the opening of this period. See 1938 FrANKLIN D. Roosevelt, Recommendations to the Congress to Curb Monopolies and the Concentration of Economic Power, in THE PUBlic PAPERS AND AdDRESSES OF FRANKLIN D. RoOSEVELT 305, 306 (Samuel I. Rosenman ed., 1941), https://quod.
} 
The charge was led by Thurman Arnold, President Roosevelt's 1938 appointee to the post of Assistant Attorney General in the Antitrust Division of the Department of Justice. ${ }^{74}$ Arnold, a Yale law professor, vigorously pursued an agenda of breaking up industry cartels. ${ }^{75}$ In his view, monopolistic and oligopolistic industries encouraged higher prices, constrained supply, and slowed innovation; the last point was exemplified by an agreement under which lightbulb manufacturers agreed not to invent low-wattage fluorescent bulbs so as not to cut into the electric utilities' profits. ${ }^{76}$

Patents were seen, at the time, as a primary vehicle for bigbusiness abuse to bolster those cartels. In a 1942 essay in the Atlantic Monthly, Arnold described the patent laws as the "principal smoke screens under which domestic and international cartels have cloaked their activities," insofar as arrangements such as patent pools enabled firms to divide up markets, fix prices, and restrict consumerbeneficial innovation. ${ }^{77}$ These views were not unique: Roosevelt himself criticized the use of patents "to create industrial monopolies." 78 Roosevelt's call to end monopoly abuse led Congress in 1938 to create the Temporary National Economic Committee to "make a full and complete study and investigation ... on monopoly and the concentration of economic power,"79 and it is indicative of the close tie between patents and antitrust that the TNEC's first formal non-introductory proceeding was on "the effect of the use of patents upon industry." ${ }^{80}$ In its final

lib.umich.edu/p/ppotpus; see also Gene M. Gressley, Thurman Arnold, Antitrust, and the New Deal, 38 Bus. Hist. REV. 214, 217 (1964).

${ }^{74}$ See Gressley, supra note 73, at 217-18; Spencer Weber Waller, The Antitrust Legacy of Thurman Arnold, 76 ST. JOHN's L. REV. 569, 574-77 (2004).

${ }^{75}$ See Gressley, supra note 73, at 222-25 (describing Arnold's approach to antitrust enforcement); Waller, supra note 74, at 588-94 (listing cases brought). In his later years, Arnold co-founded the law firm Arnold \& Porter.

${ }^{76}$ See Thurman W. Arnold, The Abuse of Patents, 24 J. PAT. OfF. SOC'Y 531, 53940 (1942); see also id. at 536-38 (industry agreement not to develop synthetic rubber technology); $i d$. at 538-39 (agreement not to improve flashlight bulbs in service of battery manufacturers).

${ }^{77} \mathrm{Id}$. at 536 .

${ }^{78}$ Roosevelt, supra note 73, at 318.

79 Joint Resolution to Create a Temporary National Economic Committee, ch. 456, § 2(a), 52 STAT. 705, 705 (1938).

${ }^{80}$ Investigation of Concentration of Economic Power: Hearings Before the Temporary National Economic Comm., 75th Cong. 253, 253 (1939-1941). Arnold was a member of the committee and the initial witness at the patent hearing. See id. at 254 . 
report in 1941, the TNEC's lead suggestions for legislative changes focused on patents, with the report finding that "[n]o one can read the testimony developed before this committee on patents without coming to a realization that in many important segments of our economy the privilege accorded by the patent monopoly has been shamefully abused." 81

While these concerns about patents arose independently from the war, Arnold and others drew an immediate connection: Patents enabled cartels, cartels enjoyed benefits from constraining supply and limiting certain forms of technological advancement, and limits on supply and innovation hampered the war effort. ${ }^{82}$ In March 1941 the House Committee on Patents held a hearing to consider a bill that would enable the Commissioner of Patents to declare certain patents "necessary to the national defense" and thereby restrict injunctive relief on those patents "during the continuance of the national emergency" that the president had declared as of September 1939. ${ }^{83}$ There, Arnold testified on how patent arrangements constrained military supply, describing in particular how a deal between the dominant optical glass manufacturers, Bausch \& Lomb in America and Zeiss in Germany, was creating a shortage of military-grade optical lenses: "our production goes down ... and German production goes shooting up." 84

At a time when American entry into the war was still speculative, the Patents Committee found the war-patent connection too speculative as well. Committee Chair Charles Kramer harshly

${ }^{81}$ INVESTIGATION OF CONCENTRATION OF ECONOMIC POWER: FinAL REPORT AND RECOMMENDATIONS OF THE TEMPORARY NATIONAL ECONOMIC COMMITTEE, S. DoC. No. 77-35, at 36 (1941), https://catalog.hathitrust.org/Record/001430359. The report specifically recommended compulsory licensing of patents, prohibition on use-restricted licenses, recordation of assignments, limitations on infringement actions, and forfeiture of patents for licensing violations. Id. at 3637. Well ahead of its time, the report also called for creation of a single patent appeals court and a patent term of twenty years from filing rather than seventeen years from issuance. $I d$. at 37 .

${ }^{82}$ See, e.g., Arnold, supra note 76, at 536-37.

${ }^{83}$ H.R. 3360, 77th Cong. $\S 1$ (1941), reprinted in Preventing Publication of Inventions and Prohibiting Injunctions on Patents: Hearings on H.R. 3359 and H.R. 3360 Before the H. Comm. on Patents, 77th Cong. 55 (1941), https://catalog. hathitrust.org/Record/002009460.

${ }^{84}$ Preventing Publication of Inventions and Prohibiting Injunctions on Patents, supra note 83, at 119; see also id. at 148 (statement of Francis M. Shea, Assistant Att'y Gen.) ("Bausch \& Lomb and Zeiss have unlawfully combined and conspired to suppress and limit competition in military optical instruments ...."). 
criticized Arnold, questioning the accusations against Bausch \& Lomb $^{85}$ and later flatly accusing Arnold of "attacking" the patent system. ${ }^{86}$ More importantly, the Committee asked military representatives to assess the need for the bill; the representatives could not identify any. Major Francis H. Vanderwerker, representing the War Department, supported the patent bill based on the possibility that "in some of the other Government departments there may be a need for this type of legislation," but testified that "the War Department has no present need for a bill of this character." 87 Lieutenant Commander K.C. Caldwell noted that the Navy Department was conducting an investigation for problematic patents, and knew of "instances" where patents had hampered the Navy, but did not identify any specifically. ${ }^{88}$

Skepticism about the effect of patents on national preparedness would quickly change once the threat of war became real on December 7, 1941. Just months after the attack on Pearl Harbor, the Senate Committee on Patents took up a wartime measure that went further than the House bill, giving the president power to mandate compulsory licensing of any patent "upon such terms and for such period of time as the President may prescribe," and further power "to acquire patents, applications therefor, inventions, or licenses under any of the foregoing, by donation, purchase, taking or otherwise." 89 Across April-August 1942, the Committee held thirtythree days of hearings on that bill and the patent system generally. ${ }^{90}$ The chair of the Committee, Senator Homer T. Bone, opened the hearings with a strong statement on the role of government patent use:

No right fashioned by law is superior to the public welfare or national interest. The very fact that men are to die to preserve our system and our way of life leaves only one conclusion; that is, that patent rights and every other form of property right must be subordinated to the all-out effort confronting us. It is

\footnotetext{
${ }^{85}$ See id. at $119-20$.

${ }^{86} \mathrm{Id}$. at 131.

${ }^{87}$ See id. at 107.

${ }^{88} \mathrm{Id}$. at 109.

${ }^{89}$ S. 2303, 77th Cong. $\S \S 1(a), 2$ (1942), reprinted in 1 Hearings on S. 2303

Before the S. Comm. on Patents, 77th Cong. 1 (1942), https://catalog. hathitrust.org/Record/001511288.

${ }^{90}$ See 1 Hearing on S. 2303, supra note 89.
} 
crystal clear that in this hour of trial the profit motive cannot be accented without inviting the destruction of morale. . . .

The American patent system enters the trenches and goes along on the battlefield with our boys. To the extent that they achieve victory, to the same extent do we achieve safety and security for our social and economic system. ${ }^{91}$

The House Patents Committee, for its part, also revisited patents during the exigencies of war in October 1942, as it considered an emergency legislative proposal from the War and Navy Departments. ${ }^{92}$ The statutory proposal, subsequently enacted into law, was intended "to aid in the successful prosecution of the War",93 and had two primary effects. First, the statute cleared up an ambiguity as to whether subcontractors were covered under $\S 1498$, making explicit that "a contractor, a subcontractor, or any person, firm, or corporation" could enjoy immunity to a patent infringement suit based on government use. ${ }^{94}$ Second, the statute enabled a government department to identify patent royalties "which are believed to be unreasonable or excessive" and to terminate payment of such royalties, fixing an alternate rate that the department head determined to be "fair and just, taking into account the conditions of wartime production." 95 The patentee in that situation was not stuck with the department-authorized royalty, but could bring suit in federal court to recover any deficiency from "fair and just compensation." 96 This provision responded to an observed situation in which the government already had a licensing arrangement in place with a patent holder, but the royalty rates, though reasonable

${ }^{91} I d$. at 3-4.

${ }^{92}$ See Adjusting Royalties for the Use of Inventions for the Benefit of the United States: Hearing on H.R. 7620 Before the H. Comm. on Patents, 77th Cong. 1-4, 31-32 (Oct. 13-15, 1942) [hereinafter Royalty Adjustment Act Hearing], https:// catalog.hathitrust.org/Record/100669202.

${ }^{93}$ Royalty Adjustment Act, ch. 634, § 1, 56 STAT. 1013, 1013 (Oct. 31, 1942).

${ }^{94} I d$. $\S 6,56$ STAT. at 1014 . This defect in the statute had been identified in the 1941 House hearing, for example by Commissioner of Patents Conway Coe, who testified that it was "open to doubt, I should say, as to whether or not a subcontractor falls under the provisions" of the 1910 Act. See Preventing Publication of Inventions and Prohibiting Injunctions on Patents, supra note 83, at 56; see also id. at 57 (testimony of Major Vanderwerker).

${ }^{95}$ Royalty Adjustment Act $\S 1,56$ STAT. at 1013.

${ }^{96}$ Id. § 2, 56 STAT. at 1013. 
in peacetime conditions, proved excessive in view of massively increased wartime demands; ${ }^{97}$ in Newport News Shipbuilding \& Dry Dock Co. v. Isherwood a court had held that $\S 1498$ was inapplicable where the government already had a license in place. ${ }^{98}$ The new royalty-termination provision was carefully limited: The statute repeatedly called on agencies and courts to consider "the conditions of wartime production," 99 and included a sunset of the provision six months after termination of the war. ${ }^{100}$

In stark contrast to the 1941 House committee hearing, by 1942 the military had found numerous instances of patents interfering with wartime production. The Secretaries of War and the Navy wrote of "a number of instances" of existing patent royalty arrangements that "when applied to the enormous quantities needed for the prosecution of the war such royalty rates are regarded in some cases as exorbitant, excessive, and unfair."101 Colonel Earl S. Patterson offered more detail on behalf of the War Department, testifying as to the government's difficulties with patents on airplane parts, recoil springs, steel milling, and radio technology. ${ }^{102}$ The Senate report on the legislation acknowledges the "cost of patents in war procurement" as the driving force behind the law. ${ }^{103}$ With this evidence and general consensus in favor, the bill swiftly passed Congress and was enacted into law.

${ }^{97}$ See Royalty Adjustment Act Hearing, supra note 92, at 17.

${ }^{98}$ See 5 F.2d 924, 934 (1925) (government use statute inapplicable where "[t]here was no use of a patent by the United States, without license of the owner").

${ }^{99}$ Royalty Adjustment Act $\S \S 1-2,56$ STAT. at 1013-14.

${ }^{100}$ See id. $\S 7,56$ STAT. at 1014.

${ }^{101}$ Letter from Henry L. Stimson, Sec'y of War, to Speaker, House of Representatives, in Royalty Adjustment Act Hearing, supra note 92, at 3, 3; accord Letter from James Forrestal, Acting Sec'y of the Navy, to Charles Kramer, House of Representatives, in Royalty Adjustment Act Hearing, supra note 92, at 31,32 .

${ }^{102}$ See Royalty Adjustment Act Hearing, supra note 92, at 18-19, 22. The Navy's representative similarly identified examples of problematic patent licensing arrangements, though he did not identify specific technologies, perhaps out of secrecy concerns. See id. at 42-44.

${ }^{103}$ See ADJUSTMENT OF ROYALTIES FOR THE USE OF INVENTIONS FOR THE BENEFIT OF THE UNITED STATES, S. REP. NO. 77-1640, at 2 (1942), https://books.google. com/books?id=FNx8zn1cIfgC\&pg=RA14-PA1\&lpg=RA14-PA1. 


\section{Bioterrorism Threats After September 11}

Government patent use and $\S 1498$ again took center stage amidst an immediate national threat following the terrorist attacks on the United States on September 11, 2001. ${ }^{104}$ This historical episode confirmed the nondisruptive and beneficial role that $\S 1498$ can play and indeed suggests broad acceptance of use of $\S 1498$ in times of need.

In the two months following the September 11 attacks, Congress, the Bush Administration, and the public became aware of a likely possibility of bioterrorism, specifically in the form of anthrax spores being blanketed over a large population. ${ }^{105}$ At the time, the only approved antibiotic for treating anthrax was ciprofloxacin, sold under the brand name Cipro. The drug quickly became a household name after news anchor Tom Brokaw, himself the recipient of an anthrax-laden letter, ran a television segment ending with the line, "in Cipro we trust." ${ }^{106}$ Calls for a federal

104 The episode described here has been covered generally a number of times. See, e.g., Cahoy, supra note 26, at 126-27, 171-73 (focusing on monetary compensation to patent holder); Duan, supra note 48, at 392-94 (national security implications); Erika Mullenbach, The Influence of Disease on the Evolution of U.S. Patent Law and Policy Towards Foreign Patent Laws in the Late Twentieth to Early Twenty-First Century, 7 TUL. J. TeCH. \& INTELL. PROP. 227, 239-42 (2005) (impact on access to AIDS treatments in Africa); Shapiro, supra note 17, at 39-41, 59-61 (pharmaceutical industry impact). One particularly interesting source describes the situation from the perspective of Bayer's marketing and brand management campaign, concluding that "Bayer AG was able to be a good and ethical corporate citizen, placate the regulatory environment, impede entry for competitors, and enable the US government to provide the public with lifesaving medicines." Hagai Gringarten, Bayer, Ethics, and the Anthrax Scare: Leveraging National Crisis for a Public Relations Bonanza, in ETHICAL BRANDING AND MARKETING: CASES AND LESSONS 69, 76 (Hagai Gringarten \& Raúl Fernández-Calienes eds., 2019).

105 See, e.g., Effective Responses to the Threat of Bioterrorism: Hearing Before the Subcomm. on Public Health of the S. Comm. on Health, Education, Labor, and Pensions, 107th Cong. 5 (Oct. 9, 2001) (statement of Sen. Bill Frist).

${ }^{106}$ Howard Kurtz, Tom Brokaw, Putting a Familiar Face on the Anthrax Story, WASH. PoST (Oct. 18, 2001), https://www.washingtonpost.com/archive/lifestyle/ 2001/10/18/tom-brokaw-putting-a-familiar-face-on-the-anthrax-story/d3b2c39b74b3-4e66-8357-291a3f55f4c5/; see Donald G. McNeil Jr., A Rush for Cipro, and the Global Ripples, N.Y. TIMES (Oct. 17, 2001), https://www.nytimes.com/2001/ 10/17/world/a-nation-challenged-the-drug-a-rush-for-cipro-and-the-globalripples.html. Other treatments may have been equally effective or possibly superior; the national focus on ciprofloxacin may have been a failure of messaging 
stockpile of the drug, however, met a roadblock: the German firm Bayer AG held a patent on ciprofloxacin, but was unable to meet the government's requisition amount for a sufficient stockpile; the company reported that it would require almost two years to manufacture enough. ${ }^{107}$ While generic manufacturers estimated that they could fulfill the requisition in three months, Bayer refused to license the patent. ${ }^{108}$

Bayer's patent standoff led to numerous calls to invoke $\S 1498$ to enable generic manufacturing of the drug. Alfred Engelberg, a "smart and tough-as-nails attorney" known for his role in the HatchWaxman Act governing pharmaceuticals, 109 authored a memorandum to Senator Chuck Schumer, laying out the case for invoking the law and a procedure for doing so. Engelberg proposed that the Department of Health and Human Services provide a blanket government authorization for generic firms to submit federal

consistency from federal health experts. See Elin Gursky et al., Anthrax 2001: Observations on the Medical and Public Health Response, 1 BIOSECURITY \& BIOTERRORISM: BIODEFENSE STRATEGY PRAC. \& SCI. 97, 105 (2003) (noting CDC's recommendation of doxycycline rather than ciprofloxacin); UPMC CTR. for Health SeC., How to Steward Medical Countermeasures and Public Trust in an EMERgency: A COMMUNICATION CASEBOOK FOR FDA AND ITS PUBliC HEALTH PARTNERS 111-12 (2016), https://www.centerforhealthsecurity. org/our-work/events/2016\%20FDA\%20MCM/Summary. Some have used the availability of alternatives to suggest that the anthrax scare was not an actual emergency, see, e.g., Azar, supra note 32, but that would appear to be hindsight reasoning.

${ }^{107}$ See Elisabeth Bumiller, Administration Won't Allow Generic Versions of Drug, N.Y. TiMES (Oct. 18, 2001), https://www.nytimes.com/2001/10/18/us/nationchallenged-response-administration-won-t-allow-generic-versions-drug.html.

${ }^{108}$ See id. For its part, Bayer thought that its production capacity was sufficient for U.S. demand and questioned whether generic manufacturers could ramp up production so quickly, see Vanessa Fuhrmans \& Ron Winslow, Bayer Works to Meet Soaring Cipro Demand as It Starts Campaign to Keep Patent in U.S, WALL ST. J. (Oct. 22, 2001), https://www.wsj.com/articles/SB1003698325298160000, despite simultaneously "exploring whether to ask some rival drug companies to produce some of its antibiotic Cipro to make certain an adequate supply of the drug is available," see Vanessa Fuhrmans, Bayer May Ask Its Rivals for Help Producing Anthrax Antibiotic Cipro, WALL ST. J. (Oct. 18, 2001), https://www. wsj.com/articles/SB100334769597877200.

109148 CONG. REC. 15,356 (2002) (statement of Sen. Hatch); Competition in the Pharmaceutical Marketplace: Antitrust Implications of Patent Settlements: Hearing Before the S. Comm. on the Judiciary, 117th Cong. 32 (2001). 
bids for procurement. ${ }^{110}$ Just days later, the senator called for invocation of the law in a press conference, ${ }^{111}$ leading to national interest in the possibility of invoking government use of Bayer's patent. $^{112}$

Engelberg's memorandum is succinct in its analysis of $\S 1498$. It simply observes "ample authority" and "overwhelming precedents" supporting the use of $\S 1498$ to procure a stockpile of ciprofloxacin, ${ }^{113}$ quotes a few cases, and moves on to more detailed analysis of practical questions of regulatory approval and dismissal of ongoing patent infringement litigation. The memorandum does not discuss effects on incentives to innovate or other policy implications of invoking government patent use at all.

One can imagine a variety of reasons for this summary treatment of $\S 1498$, but the likeliest is the prior context. In the decades prior to 2001, the appropriateness of $\S 1498$ in the context of federal procurement - in both emergency and non-emergency situations - was settled. A 1958 decision of the Comptroller General addressed the question of whether procurement officers should consider patent or patent license holdings in the course of choosing among bids. ${ }^{114}$ The Comptroller General's answer was no, based on an understanding that any standard procurement invitation automatically provided the requisite authorization and consent under $\S 1498 .{ }^{115}$ The U.S. government was, and still is, free to procure whatever it needs from whomever it wants without permission from patent holders. The Comptroller General's decision

${ }^{110}$ Because the memorandum does not appear to be otherwise available in any permanent form, it is reprinted as an appendix to this Article with permission from Mr. Engelberg. See infra Part V.

111 See Senator Seeks Generic Cipro, CNN MONEY (Oct. 16, 2001), https://money. cnn.com/2001/10/16/news/generic_cipro.

112 See Shankar Vedantam \& Terence Chea, Drug Firm Plays Defense in Anthrax Scare, WASH. POST (Oct. 20, 2001), https://www.washingtonpost.com/archive/ politics/2001/10/20/drug-firm-plays-defense-in-anthrax-scare/aa3b0b39-2cb3-

4264-a360-aed1babbe8f8. A bill was introduced a few weeks later to enable the HHS Secretary to authorize compulsory licensing of patents during a public health emergency. See H.R. 3235, 107th Cong. §2(a) (Nov. 6, 2001); see also Avedissian, supra note 26, at 261-62.

${ }^{113}$ In a contemporaneous interview, Engelberg remarked, "[i]t boils down to something very simple. . . The government has the right to procure whatever it needs for government purposes." Bumiller, supra note 107.

114 See Herbert Cooper Co., 38 Comp. Gen. 276, 277 (1958), https://catalog. hathitrust.org/Record/003100408.

${ }^{115} I d$. at 279 . 
sparked a wave of patentee-friendly legislative proposals across the 1960s to restrict the U.S. government's patent-blind procurement practice; none of the bills succeeded. ${ }^{116}$ As government procurement officers purchased patented technologies again and again in subsequent decades, case law confirmed repeatedly that $\S 1498$ is automatically invoked and "the patentees' sole remedy [is] a suit against the United States in the Court of Claims." "17 Given this longsettled federal policy of using $\S 1498$ as a routine part of government contracting, there was no need to treat in depth the question of using $\S 1498$ for procuring ciprofloxacin.

In the wake of Senator Schumer's call, Bayer rapidly moved to oppose any invocation of $\S 1498$. Bayer immediately launched a comprehensive branding campaign (including a $\$ 3$ million buy for full page advertising in all the major papers) promising that the company would "stand ready to support the United States government providing Cipro to meet emergency needs." 118 Bayer and other pharmaceutical industry representatives also lobbied Congress and the administration heavily "to provide reassurance of Bayer's commitment."119 Bayer also attempted to paint government patent use as misguided, even illegitimate, "emphasiz[ing] the importance of patents for research and investment." ${ }^{120}$ Remarkably, the Bush Administration initially sided with Bayer on the aptness of $\S 1498$. Likely concerned about contradicting its international opposition to compulsory patent licensing-having rejected calls to invoke compulsory licensing on HIV/AIDS drug patents in the Global South as the landmark 2001 Doha Declaration was being

${ }^{116}$ See Mossinghoff \& Allnutt, supra note 24, at 16-27 (describing legislative reform proposals).

117 TVI Energy Corp. v. Blane, 806 F.2d 1057, 1060 (Fed. Cir. 1986); see also Trojan, Inc. v. Shat-R-Shield, Inc., 885 F.2d 854, 857 (Fed. Cir. 1989); W.L. Gore \& Assocs., Inc. v. Garlock, Inc., 842 F.2d 1275, 1282 (Fed. Cir. 1988); Motorola, Inc. v. United States, 729 F.2d 765, 771-72 (Fed. Cir. 1984); Decca Ltd. v. United States, 640 F.2d 1156, 1166-67 (Ct. Cl. 1980); Rel-Reeves, Inc. v. United States, 534 F.2d 274, 298 (Ct. Cl. 1976); Roberts v. Herbert Cooper Co., 236 F. Supp. 428, 430 (M.D. Pa. 1959) ("No extended discussion is required on the question whether this action falls within the provisions of 28 U.S.C. $§ 1498 . ”)$.

118 Paul Holmes, Bayer Responds to Cipro Crisis, PRovoKe (Nov. 19, 2001), https://www.provokemedia.com/latest/article/bayer-responds-to-cipro-crisis.

${ }^{119}$ See Paul Holmes, In Cipro We Trust, PRovoKe (Oct. 22, 2002), https://www. provokemedia.com/latest/article/in-cipro-we-trust.

${ }^{120}$ Id.; see also Fuhrmans \& Winslow, supra note 108; Gringarten, supra note 104 , at $77-79$. 
negotiated $^{121}$ — the Bush administration publicly rebuked calls to invoke the statute. A spokesman for HHS said that "[w]e don't feel there's a need to lift the patent at this time,"122 and HHS Secretary Tommy Thompson more bluntly rejected calls to "break" Bayer's patent: "No. 1, it's illegal," the Wall Street Journal quoted him as saying. ${ }^{123}$

As pressure mounted, though, the government appeared to change course: Secretary Thompson 'threatened to bypass Bayer's patent" and was "ready to ask Congress for special legislation that would make the government exempt from paying any damages to Bayer for breaking the patent." ${ }^{124}$ Ultimately, Bayer agreed to make substantial concessions in negotiations with the government, including massive increases in manufacturing and a price cut on ciprofloxacin to $\$ 0.95$ or less per pill, compared to $\$ 1.83$ that the government had been paying previously and the wholesale price of $\$ 4.67 .^{125}$

What role $\S 1498$ played in that ultimate deal is a Rashomon question with at least three possible answers. The majority view, as reported by almost all commentators at the time and subsequently, was that Thompson did indeed threaten to invoke $\S 1498$, which "provide[d] the government with the necessary leverage" to force Bayer into a concession. ${ }^{126}$ Indeed, Bayer's financial statements

${ }^{121}$ See Divya Murthy, The Future of Compulsory Licensing: Deciphering the Doha Declaration on the TRIPs Agreement and Public Health, 17 AM. U. INT'L L. REV. 1299, 1313-16 (2002).

${ }_{122}$ Amy Harmon \& Robert Pear, Canada Overrides Patent for Cipro to Treat Anthrax, N.Y. Times (Oct. 19, 2001) https://www.nytimes.com/2001/10/19/ business/nation-challenged-treatment-canada-overrides-patent-for-cipro-treatanthrax.html.

${ }^{123}$ Fuhrmans, supra note 108; see also Bumiller, supra note 107.

${ }^{124}$ Keith Bradsher, Bayer Agrees to Charge Government a Lower Price for Anthrax Medicine, N.Y. TIMES (Oct. 25, 2001), https://www.nytimes.com/2001/ 10/25/business/nation-challenged-cost-bayer-agrees-charge-government-lowerprice-for-anthrax.html; see also Dan Ackman, A New Deal on Cipro, FORBES (Oct. 24, 2001), https://web.archive.org/web/20040907005526/http://www. forbes.com:80/2001/10/24/1024topnews_print.html (quoting Thompson saying that Bayer is "going to meet our price, which is less than $\$ 1$, or else we're going to go to Congress and ask for some support to go in and do some other business"). ${ }^{125}$ See Bradsher, supra note 124.

${ }^{126}$ Brennan et al., supra note 11, at 303; see, e.g., Jennifer R. Andrew, Swine Flu, Bird Flu, Sars, Oh My-Applying the Precautionary Principle to Compulsory Licensing of Pharmaceuticals Under Article 31 of Trips, 2011 Mich. ST. L. REV. 
noted that "in response to anthrax bioterror attacks in the United States in 2001, the U.S. and Canadian governments contemplated compulsory licensing of our ciprofloxacin antibiotic," which seems to confirm that $\S 1498$ did come up in Bayer's negotiations. ${ }^{127}$ Thompson's general counsel Alex Azar, on the other hand, contended that Thompson "never threatened to break Bayer's patent," though Thompson did advise Bayer that he was willing to ask Congress for "authority to procure generics" in a manner that was "hardly the same thing as threatening a company." Azar repeated that statement at his 2018 nomination for HHS Secretary. ${ }^{128}$ Bayer's CEO Helge Wehmeier advanced a third view and claimed that Thompson had not even gone that far-according to Wehmeier, the negotiation over Cipro took "less than ten minutes" with no invocation of leverage, from $\S 1498$ or Congress. ${ }^{129}$

The Wehmeier and Azar views that $\S 1498$ played no role in the negotiations have found little traction among historians. Even those critical of $\S 1498$ generally accept that HHS invoked it or some other threat of government patent use en route to negotiating a favorable

405, 411 (2011); Bayer's Reasons for Not Giving Cipro Away; USA Slammed for "Double Standards," PHARMA LeTtER (Nov. 7, 2001), https://www. thepharmaletter.com/article/bayer-s-reasons-for-not-giving-cipro-away-usaslammed-for-double (noting "USA's threat to override Bayer's patent"); Jill Carroll \& Ron Winslow, Bayer Agrees to Slash Price for Cipro Drug, WaLl ST. J. (Oct. 25, 2001), https://www.wsj.com/articles/SB1003966074330899280 (describing "high-stakes threat by Tommy Thompson ... to break Bayer's patent"); Matt Fleischer-Black, The Cipro Dilemma, AM. LAW., Jan. 2002, at 53; Aaron S. Kesselheim \& Jerry Avorn, Biomedical Patents and the Public's Health: Is There a Role for Eminent Domain?, 205 J. AM. MED. Ass'N 434, 435 (2006); Mullenbach, supra note 104, at 227; Ho, supra note 17, at 113-14; Jennifer Penman \& Fran Quigley, Better Late than Never: How the U.S. Government Can and Should Use Bayh-Dole March-in Rights to Respond to the Medicines Access Crisis, 54 WiLlamette L. ReV. 171, 187-88 (2017).

${ }^{127}$ See Bayer AG, Registration Statement (Form 20-F), at 10 (June 24, 2002), https://www.sec.gov/Archives/edgar/data/1144145/000115697302000306/

f00360e20vf.txt; James Love, Secretary Alex Azar's Comment on 28 USC 1498 Submitted for the Record of the 2018 Confirmation Hearings, KNOWLEDGE ECOLOGY INT'L (Aug. 1, 2018), https://www.keionline.org/28631.

${ }^{128}$ Azar, supra note 32; accord Nomination of Alex Michael Azar II: Hearing Before the S. Comm. on Finance, 115th Cong. 119-20 (Jan. 9, 2018), https://www. govinfo.gov/content/pkg/CHRG-115shrg34341/pdf/CHRG-115shrg34341.pdf ("Bayer was never threatened with the use of section 1498 . ...").

${ }^{129}$ Holmes, supra note 118; see also Carroll \& Winslow, supra note 126. 
deal for the government, ${ }^{130}$ and Azar's letter appears to not to have been cited in any subsequent literature. ${ }^{131}$

But Bayer's massive public relations push, coupled with the Bush Administration's initial vocal disavowal of the appropriateness of $\S 1498$, seems to have had an important (and underacknowledged) legacy, shifting views of $\S 1498$ from a routine, beneficial government power commonplace in federal procurement to a dramatic incursion too extreme for use even in the face of a credible terrorist threat — or even "illegal." Legal observers at the time were left "scratching their heads" over this change. ${ }^{132}$ This history suggests that contemporary views of $\S 1498$ are of relatively recent vintage, rather than being any long-held understanding about the statute. The now widespread "conventional wisdom" that $\S 1498$ is an "exceptional" remedy to be used only in a vanishingly small set of circumstances ${ }^{133}$ seems to be a product of just the last two out of the eleven decades the statute has been on the

130 See F. Scott Kieff, Removing Property from Intellectual Property and (Intended) Pernicious Impacts on Innovation and Competition, 19 SUP. CT. ECON. REV. 25, 35 (2011) (discussing the "infamous" Cipro case in which "the Government's threat . . . was enough to get Bayer, the patentee, to drop its price"); Natalie Goldberg, The Bayh-Dole Act: Is It the Proper Treatment for the Big Pharma Price-Gouging Epidemic?, 29 FED. CIR. B.J. 387, 414 (2020) (discussing arguments against compulsory licensing but observing that "the Government has also taken or threatened to utilize compulsory licensing . . to address anthrax with Cipro"); Eileen M. Kane, Achieving Clinical Equality in an Influenza Pandemic: Patent Realities, 39 SetOn HALl L. REV. 1137, 1164 (2009) ("The possibility that the U.S. government might issue a compulsory license under 28 U.S.C. $\S 1498 \ldots$ was very real and represented a significant departure from existing reluctance to exercise such power."); see also Kirby W. Lee, Permitted Use of Patented Inventions in the United States: Why Prescription Drugs Do Not Merit Compulsory Licensing, 36 IND. L. REV. 175, 175-76, 196 (2003) (noting calls to "override Bayer's patent rights" but not indicating a view as to whether $\S 1498$ was used); Jason D. Ferrone, Note, Compulsory Licensing during Public Health Crises: Bioterrorism's Mark on Global Pharmaceutical Patent Protection, 26 SufFOlK TRANSNAT'L L. REV. 385, 409-10 (2002) (criticizing the "contemplation of compulsory licensing of ciproflaxin [sic]" as rendering "the U.S.-championed TRIPS Agreement less effective").

${ }^{131}$ A search of the HeinOnline Law Journal Library for "Azar w/50 cipro*" and JSTOR for "(Azar cipro* 50) AND patent" produced no relevant results other than one of our own articles.

132 Fleischer-Black, supra note 126 (quoting a "former Reagan administration health official" saying, "They can't seriously be suggesting that [the government] can't buy generic Cipro").

${ }^{133}$ See sources cited supra notes 2-13. 
books. For much more of our nation's history, $\S 1498$ was used routinely, especially in times of national emergency.

At the same time, if Engelberg and Schumer had not put $\S 1498$ on the table, Bayer may not have made that massive public relations push or been as conciliatory to the federal government as it eventually was. Bayer's efforts were described as "[u]ncertain" and "detached" in the days before Schumer proposed invoking $\S 1498$, and Canada not only threatened but actually ordered a compulsory license. ${ }^{134}$ The company's media and lobbying salvo focused not just on reassuring the public of Bayer's manufacturing capacities, but also on "the importance of the patent issue," 135 suggesting that Bayer's public response was likely triggered by an expectation that $\S 1498$ might actually be used. If that was so, then the Cipro crisis both confirmed the statute's vitality and simultaneously marginalized it in the years to come.

\section{E. Lessons for the COVID-19 Pandemic}

The foregoing history shows that for most of the last century, $\S 1498$ and government patent use more generally have been viewed as ordinary and integral policy tools with which the U.S. government can face emergencies of national dimension, including public health crises. The COVID-19 pandemic is not a war or a threat of terrorism, but it presents exigencies of the same ilk. Millions of human lives are at stake. Success depends on rapid, collaborative technological developments. ${ }^{136}$ A patent system that favors single-firm control over a technological field clashes with that demand. The promise of pecuniary gain from patent protection is of course a strong motivator for innovation in emergencies as in ordinary times. But this pandemic, like all other crises, may demand that holders of patents, as with any other roadblocks to fast deployment of technology, temporarily cede some pecuniary gain to limit a crisis of national, existential dimensions.

In addition to this overarching point, several other lessons may

${ }^{134}$ Edmund L. Andrews, Drug Maker Seems Uncertain in Response to Cipro Frenzy, N.Y. TIMES (Oct. 20, 2001) https:/www.nytimes.com/2001/10/20/ business/nation-challenged-drug-maker-drug-maker-seems-uncertain-responsecipro-frenzy.html; see Gringarten, supra note 104, at 75 (noting "two weeks of no decisive response to the crisis").

135 Holmes, supra note 118.

136 See Matt Apuzzo \& David D. Kirkpatrick, Covid-19 Changed How the World Does Science, Together, N.Y. TIMES (Apr. 1, 2020), https://www.nytimes.com/ 2020/04/01/world/europe/coronavirus-science-research-cooperation.html. 
be drawn about the role of government patent use in national crises. First, there is consistent general recognition that emergency conditions demand greater government involvement in directing use of patents. The U.S. government's creation of the Manufacturers' Aircraft Association after a threat of condemnation of patents exemplifies this, ${ }^{137}$ as does the Royalty Adjustment Act, when Senator Bone proclaimed that the "patent system enters the trenches and goes along on the battlefield with our boys." 138

In the past, even the patent holders and lawyers who typically opposed government patent use quickly came around to accepting it in emergencies. Patent attorney Lawrence Langner offered a nearly line-by-line rebuttal to Thurman Arnold's 1942 patents-and-cartels article in the Atlantic Monthly, but Langner nevertheless agreed that "the grant of compulsory licenses under all patents during the war period ... can be accepted in principle if it is surrounded by the proper safeguards and the license is limited to the war period."139 Similarly, at the 1942 House hearing, the American Patent Law Association "approve[d] Government regulation of royalties to be paid by the Government under patents during the emergency of war conditions," 140 and the American Bar Association approved in principle the "compulsory granting of licenses under patents in furtherance of the war effort." ${ }^{141}$ In the 2001 anthrax scare, a representative for the pharmaceutical industry agreed with "[p]utting aside personal and company considerations in a time of crisis," which included "making some compromises," 142 and another industry executive found the Cipro negotiations to be "completely legitimate" and even would have accepted "abrogation of patents in the time of a true national emergency." 143 Despite the

137 See supra notes 55-61 and accompanying text.

1381 Hearing on S. 2303, supra note 89, at 4.

${ }^{139}$ Lawrence Langner, We Depend on Invention: An Answer to Thurman Arnold, Atlantic Monthly, July 1942, reprinted in 24 J. PAT. OFF. SoC'Y 545, 561 (1942).

140 Royalty Adjustment Act Hearing, supra note 92, at 52 (statement of Karl Fenning, American Patent Law Association).

${ }^{141}$ Letter from Chester L. Davis, Am. Bar Ass'n, to Charles Kramer, House of Representatives, in Royalty Adjustment Act Hearing, supra note 92, at 51.

142 Gardiner Harris, Bayer's Cipro Will Be Profitable, Even on Discount Deal With U.S, WALL ST. J. (Oct. 26, 2001), https://www.wsj.com/articles/SB100404895 4559116840 (quoting Jeff Trewhitt on behalf of the Pharmaceutical Research and Manufacturers of America).

${ }^{143}$ Carroll \& Winslow, supra note 126 (quoting Henry McKinnell, chairman and chief executive of Pfizer Inc.) (internal quotation marks omitted). 
post-2001 conventional wisdom that rejects use of $\S 1498$ even in moments of national emergency, history demonstrates nearuniversal acceptance of government patent use in furtherance of the national interest in times of emergency.

Second, the driving motivation behind government patent use was often not lowering costs but increasing supply and accelerating technological development, a finding that is especially important in response to the dominant criticism that use of $\S 1498$ will be deleterious to future innovation. ${ }^{144}$ Patent squabbles were a key cause of the lack of American aviation technology (and plain lack of airplanes) prior to World War I, ${ }^{145}$ and in the 1930s and '40s they contributed to the supply constraints that Arnold criticized. ${ }^{146}$ The impasse over steel milling patents, as noted in the 1942 House hearing, acutely affected wartime supply, since the War Department reported that "all mills of the noninfringing type are already loaded to capacity." 147 And the threat to invoke $\S 1498$ on Bayer's ciprofloxacin patent stemmed largely from fears that Bayer could not manufacture enough antibiotic to counter a terrorist attack. To be sure, cost was often significant: The very purpose of the Royalty Adjustment Act was to adjust royalties to save the government money, ${ }^{148}$ and Cipro tablet prices were central to the HHS negotiation. ${ }^{149}$ But the possibility that a patent could cause the government simply to run out of materials during a crisis has consistently been a focus of the conversation over government patent use. The notion that government patent use will decrease innovation, then, must be tempered by historical cases of government patent use increasing both production and innovation by overcoming patent impasses.

Third, national need for patented technologies may turn out to be highly unpredictable in an emergency situation. Just months before the United States entered World War II, neither Congress nor the military departments could predict what patents would pose

\footnotetext{
${ }^{144}$ Nearly all of the criticisms of $\S 1498$ described supra notes $2-13$ rely on this proposition in some form.

145 See supra note 53.

146 See supra text accompanying notes 77-84.

${ }^{147}$ See Royalty Adjustment Act Hearing, supra note 92, at 19.

148 See id. at 21 ("The War Department is today fully cognizant of the fact that patent cost in war procurement is a vital problem.").

149 See Bradsher, supra note 124.
} 
issues or if patents would indeed pose issues at all. ${ }^{150}$ As late as August 1942, Arnold and his Department of Justice colleague Francis M. Shea hypothesized that the superiority of magnesium over steel would render the former metal of greater importance to the war effort. ${ }^{151}$ By October 1942, though, the military had identified specific patents of concern and identified patents on steel as the actual holdup. ${ }^{152}$ Pre-war hypothesizing over government patent use in the abstract was no substitute for wartime knowledge of concrete public needs. Once those exact needs were identified, expediency was of the greatest concern: Between introduction of the Royalty Adjustment Act in Congress and its enactment into law, a single month elapsed. ${ }^{153}$

Fourth, in times of crisis the U.S. government and the public have historically been willing to go far beyond $\S 1498$ with respect to government patent use. Under $\S 1498$, the government effectively receives a nonexclusive license to use a patented invention on its own behalf at a judicially-set compensation rate; the patentee's other rights and exclusivities are unaffected. ${ }^{154}$ Contrast this with the World War I authorization to condemn aviation patents, ${ }^{155}$ the World War II bill authorizing compulsory licensing at a presidentially set royalty rate, ${ }^{156}$ the Royalty Adjustment Act that undid existing government patent licenses, and Secretary Thompson's threat that he would go to Congress to "make the government exempt from paying any damages to Bayer." 157 Compared to these far more dramatic actions and threats, $\S 1498$ is relatively tame, suggesting a normative reason in favor of applying the statute more often. To the extent that $\S 1498$ is off the table in the run-up to an emergency, as many critics of the statute would like it to be, lawmakers may be pressured or compelled during the emergency to act more

${ }^{150}$ See supra text accompanying notes 82-88.

151 See Preventing Publication of Inventions and Prohibiting Injunctions on Patents, supra note 83, at 140-41; Arnold, supra note 76, at 542-43.

152 See Royalty Adjustment Act Hearing, supra note 92, at 19.

${ }^{153}$ H.R. 7620 was introduced on September 30, 1942, and enacted on October 31. See 88 CONG. REC. 7661 (1942); Royalty Adjustment Act, ch. 634, 56 STAT. 1013, 1015 (Oct. 31, 1942).

154 See § 1498(a); see also infra Part II.D.

155 See Naval Service Appropriations Act, ch. 180, 39 STAT. 1168, 1169 (1917).

156 See H.R. 3360, 77th Cong. $§ 1$ (Feb. 17, 1941), reprinted in Preventing Publication of Inventions and Prohibiting Injunctions on Patents, supra note 83, at 55 .

${ }^{157}$ Bradsher, supra note 124. 
aggressively toward patents than $\S 1498$ permits.

Finally, $\S 1498$ enhances the government's bargaining power; where it is absent patentees have proven willing to hold out even in times of crisis. ${ }^{158}$ Even after the airplane manufacturers had formed the Manufacturers' Aircraft Association to head off condemnation of their patents, they still demanded a royalty in excess of what the government found feasible. ${ }^{159}$ In view of the Newport News decision that $\S 1498$ could not affect preexisting government patent licenses even to adjust for increased wartime production needs, ${ }^{160}$ the Navy Department testified to Congress that most patent owners had "patriotically agreed to take a greatly reduced royalty," but at least some "owners of inventions have insisted on receiving the full royalty even though unreasonable." 161 In other words, where government patent use is not available as a backstop, patent owners may not act in the nation's best interests. By contrast, after Senator Schumer and (probably) HHS proposed use of $\S 1498$ in 2001, Bayer ceded some profits and negotiated a deal with the U.S. government. Indeed, starting in 2005, Roche, Inc. agreed to sublicense the patent on Tamiflu to at least nineteen contractors and made numerous pricing concessions to alleviate potential shortages of the influenza treatment in preparation for a possible avian flu pandemic; while not loudly proclaimed, § 1498 "may have played a role in persuading Roche to enter the sublicensing agreements." 162

This quiet role of $\S 1498$ as a motivator for negotiation and "corporate patriotism" is frequently missed. Epstein suggested in the wake of the Cipro deal that the government's monopsony buyer status was leverage enough to procure a price cut without resorting

158 See also Brennan et al., supra note 11, at 303 ( $\$ 1498$ "provides the government with the necessary leverage to obtain major price reductions"). This is consistent with Lemley's finding that most government patent use cases are settled in the shadow of $\S 1498$ rather than resolved judicially. See Mark A. Lemley, Contracting Around Liability Rules, 10 CAL. L. REV. 463, 473 (2012).

159 See supra text accompanying notes 55-61.

${ }^{160}$ See Newport News Shipbuilding \& Dry Dock Co. v. Isherwood, 5 F.2d 924, 934 (4th Cir. 1925).

${ }^{161}$ Royalty Adjustment Act Hearing, supra note 92, at 41 (statement of Ralph L. Chappell).

162 CONG. RESEArCh SERV., Report No. RL33159, InfluenZA Antiviral DRUGS AND PATENT LAW ISSUES 9 (2007), https://www.everycrsreport.com/ reports/RL33159.html. 
to $\S 1498,{ }^{163}$ but neither the airplane manufacturing firms in the 1910s nor the patent licensor holdouts in 1942 were swayed by that status alone-nor was Bayer, until the prospect of $\S 1498$ was concrete. Others have suggested that some drug companies' professed willingness to negotiate with the United States and other governments during the COVID-19 pandemic refutes the need to use $\S 1498 .{ }^{164}$ But this view ignores the fact that such willingness to negotiate is likely a response to the possibility of $\S 1498$ being used otherwise. The oft-repeated sentiment that patents have not been a barrier to the COVID-19 response ${ }^{165}$ may be not so much an

163 See Richard A. Epstein, Respect Bayer's Patent, Wall ST. J. (Oct. 25, 2001), https:/www.wsj.com/articles/SB122660341966225183 ("It is equally clear that wholly without resorting to this threat he had powerful leverage in price negotiations with Bayer, just as any other volume purchaser whom a monopolist can cheaply provide.").

${ }^{164}$ See, e.g., Valerie Bauman, States Demanding Gilead Drug Seizure Misread Law, Attorneys Say, BloOmBerg L. (Aug. 6, 2020), https://news.bloomberglaw. $\mathrm{com} /$ health-law-and-business/states-demanding-gilead-drug-seizure-misreadlaw-attorneys-say (disputing call for compulsory patent licensing on remdesivir because its manufacturer "Gilead has already voluntarily licensed the drug to generic drugmakers in Egypt, India, and Pakistan to boost global supply"). Gilead and other firms have indeed made various pledges of reduced or free patent licensing. See, e.g., Darrell Etherington, Medtronic Is Sharing Its Portable Ventilator Design Specifications and Code for Free to All, TECHCRUNCH (Mar. 30, 2020), https://techcrunch.com/2020/03/30/medtronic-is-sharing-its-portableventilator-design-specifications-and-code-for-free-to-all; Diane Peters \& Eric Steuer, Tech Giants Join the CC-Supported Open COVID Pledge, CREATIVE Commons (Apr. 20, 2020), https://creativecommons.org/2020/04/20/tech-giantsjoin-the-cc-supported-open-covid-pledge.

165 See, e.g., Richard Lloyd, No Evidence That Patents Are Acting as a Barrier to Covid Research, Says Bristol Myers IP Head, IAM (Aug. 4, 2020), https://www. iam-media.com/coronavirus/bristol-myers-squibbs-henry-hadad-no-evidencepatents-are-acting-barrier-covid-research (interviewing Henry Hadad, deputy general counsel of Bristol Myers Squibb) ("I have yet to hear one example of a patent being enforced or litigation being threatened in a way that has been a barrier to research with respect to covid."); Nicholson Price et al., Are COVID-19 Vaccine Advance Purchases a Form of Vaccine Nationalism, an Effective Spur to Innovation, or Something in Between?, WrITTEN DESCRIPTION (Aug. 5, 2020), https:/writtendescription.blogspot.com/2020/08/are-covid-19-vaccine-advancepurchases.html ("[T]here's no evidence that IP is being used to frustrate competition or keep early-stage [COVID-19 vaccines] developers off the market. Nor would patents likely be used to restrict the supply of any successful vaccine."). This view is questionable, given that at least one patent has already been asserted against a COVID-19 testing service. See Mike Masnick, SoftBank 
argument against $\S 1498$ as exemplification of the statute's long shadow.

\section{The Government's InNovation POLICY ToOLbOX}

As seen above, government patent use has evolved across history, as reflected in the legislative expansions of $\S 1498$ and policy debates in times of national emergency. That history brings us to the law of government patent use in place today. This Part describes $\S 1498$ in its current formulation, and in particular places the statute in the context of related innovation policy tools that have featured prominently in the COVID-19 dialogue: research grants, prizes, and patent buyouts. ${ }^{166}$ All of these policy tools variously incentivize the invention and development of new innovations or allocate existing and prospective innovations to those who need or want them, ${ }^{167}$ so the overview presented in this Part tees up a comparison of their relative merits in Part III.

\section{A. Grants}

One straightforward and hugely important means of incentivizing innovation is directly funding innovators' research and development work. The U.S. government provides over $\$ 100$ billion

Owned Patent Troll, Using Monkey Selfie Law Firm, Sues to Block Covid-19 Testing, Using Theranos Patents, TECHDIRT (Mar. 16, 2020), https://www. techdirt.com/articles/20200316/14584244111/softbank-owned-patent-trollusing-monkey-selfie-law-firm-sues-to-block-covid-19-testing-using-theranospatents.shtml.

166 See generally Joseph E. Stiglitz, Economic Foundations of Intellectual Property Rights, 57 DUKE L.J. 1693, 1719-24 (2008). Many other policy tools can incentivize new innovations and allocate existing ones; these include tax incentives for $R \& D$ and outright government seizure of patents, patented products, and the manufacturers themselves. See Daniel J. Hemel \& Lisa Larrimore Ouellette, Beyond the Patents-Prizes Debate, 92 TEX. L. REV. 303, 321 (2013), http://texaslawreview.org/wp-content/uploads/2015/08/HemelOuellette. pdf (explaining U.S. government tax incentives, such as tax credits and deductions); discussion of patent condemnation infra notes 216-218 and accompanying text.

${ }^{167}$ For more on the dual roles of intellectual property as innovation incentive and allocation mechanism, see Daniel J. Hemel \& Lisa Larrimore Ouellette, Innovation Policy Pluralism, 128 YALE L.J. 544, 547 (2019), https:// digitalcommons.law.yale.edu/ylj/vol128/iss3/1. See also James Love \& Tim Hubbard, Prizes for Innovation of New Medicines and Vaccines, 18 ANNALS HEALTH L. 155 (2009) (exploring the possibility of a hybrid patent-and-prize system that would "de-link" the innovation incentives and allocation mechanisms of the patent system); Aidan Hollis, An Efficient Reward System for Pharmaceutical Innovation (Jan. 17, 2005) (unpublished working paper), http:// www.keionline.org/misc-docs/drugprizes.pdf (same). 
per year in direct grants to federal laboratories, private and public universities, private companies, and other entities. ${ }^{168}$ Grantmaking is not monolithic; grants to recipients outside the government can, for example, be conditioned on commitments to study a particular research problem or to price affordably any inventions that result from government-funded research. As Price has shown, the grant system provides U.S. government policymakers with rich and flexible tools to incentivize and disseminate innovation. ${ }^{169}$

Grant-making has been a primary-perhaps the primaryinnovation policy tool used by the U.S. government in its COVID19 response. For example, a single COVID-19 bill, the Coronavirus Aid, Relief and Economic Security (CARES) Act, allocated over \$3 billion to the Biomedical Advanced Research and Development Authority (BARDA) and over $\$ 700$ million to the National Institute of Allergy and Infectious Diseases (NIAID) to be spent on research and development of COVID-19 vaccines, treatments, and diagnostics, mostly through grants to entities outside the U.S. government. ${ }^{170}$ As of writing, Congress has allocated the Department of Health and Human Services' "Operation Warp Speed" a staggering total of almost $\$ 10$ billion in funding for grantmaking for and procurement of a COVID-19 vaccine. ${ }^{171}$

\section{B. Prizes}

Innovation prizes are an alternative policy tool that the U.S. government could use-and already does use, to a limited

${ }^{168}$ See Hemel \& Ouellette, supra note 166, at 320 (overview of grants); MATT HOURIHAN \& DAVID PARKES, AM. ASS'N FOR THE ADVANCEMENT OF SCI., FEDERAL R\&D BUDGET TRENDS: A SHORT SUMMARY 4 (2019), https://www.aaas. org/sites/default/files/2019-01/AAAS\%20R\%26D\%20Primer\%202019.pdf (showing U.S. government spending on R\&D in excess of $\$ 100$ billion every year since the early 1980s).

${ }^{169}$ W. Nicholson Price II, Grants, 34 BerKeley TECH. L.J. 1, 31 (2019); see also Danielle Conway-Jones, Research and Development Deliverables Under Government Contracts, Grants, Cooperative Agreements and CRADAs: University Roles, Government Responsibilities and Contractor Rights, 9 COMPUTER L. REV. \& TECH. J. 181 (2004).

${ }^{170}$ Kellie Moss et al., The Coronavirus Aid, Relief, and Economic Security Act: Summary of Key Health Provisions, KAISER FAM. FOUND. (Apr. 9, 2020), https:// www.kff.org/coronavirus-covid-19/issue-brief/the-coronavirus-aid-relief-andeconomic-security-act-summary-of-key-health-provisions.

${ }^{171}$ Press Release, U.S. Dep't of Health \& Human Servs., Fact Sheet: Explaining Operation Warp Speed (June 15, 2020), https://www.hhs.gov/about/news/2020/ 06/16/fact-sheet-explaining-operation-warp-speed.html. 
extent $^{172}$ - to incentivize the creation of new technologies while simultaneously ensuring widespread access to those technologies. In a classic prize system, the government promises payment of some set amount of money $-\$ 1$ billion, say - to the first entity to create some desired innovation, such as a cold fusion reactor or a rechargeable battery manufactured without heavy metals. As a condition of claiming the prize, the winner's innovation is placed in the public domain, permitting many competing manufacturers to make and sell the innovation at near marginal cost and thereby ensuring widespread access. Some notable legal scholars and economists have endorsed prizes as a useful complement or alternative to patents, including Abramowicz ${ }^{173}$ and Stiglitz. ${ }^{174}$

In the COVID-19 pandemic, several scholars and other experts have suggested that the U.S. government use prizes to incentivize development of the most critically needed technologies, first and foremost a vaccine. ${ }^{175}$ In March of 2020, Hemel and Ouellette notably proposed a prize for a working COVID-19 vaccine of $\$ 500$ per person-approximately $\$ 165$ billion, assuming all Americans receive it - to "ensure that a vaccine would be cheap - or even free" to patients "while giving the private sector powerful incentives to pour resources into vaccine research." 176

\section{Patent Buyouts}

Patent buyouts enable expanded access to already-patented technologies. In a classic patent buyout — as in Kremer's proposala government purchases a patent from a private patent holder and

${ }^{172}$ Hemel \& Ouellette, supra note 166, at 317 (describing the U.S. government's limited use of innovation prizes); MARCY E. GALlO, CONG. RESEARCH SERV., REPORT NO. R45271, FEDERAL PRIZE COMPETITIONS (2020), https://fas.org/sgp/ crs/misc/R45271.pdf (same).

${ }^{173}$ Michael B. Abramowicz, Perfecting Patent Prizes, 56 VAND. L. REV. 114 (2003).

174 Joseph Stiglitz, Prizes, Not Patents, Project SyndiCATE (Mar. 6, 2007,), https://www.project-syndicate.org/commentary/prizes--not-patents.

175 See, e.g., Charles Duan, Coronavirus Reveals Holes in American Innovation Policy-and How to Fix Them, WASH. EXAMINER (Apr. 9, 2020), https://www. washingtonexaminer.com/opinion/coronavirus-reveals-holes-in-americaninnovation-policy-and-how-to-fix-them; Simon Lester \& Bryan Mercurio, We Need a Coronavirus Vaccine. Patents Might Slow the Process, NAT'L InT. (Apr. 7, 2020), https://nationalinterest.org/blog/buzz/we-need-coronavirus-vaccinepatents-might-slow-process-141627.

176 Daniel Hemel \& Lisa Ouellette, Want a Coronavirus Vaccine, Fast? Here's a Solution, TIME (Mar. 4, 2020), https://time.com/5795013/coronavirus-vaccineprize-challenge. 
then commits to license the patent non-exclusively for little or nothing, or disclaims the patent altogether and thereby places the patented invention in the public domain. ${ }^{177}$ In so doing, the government opens the floodgates for all to make, use, and sell the patented invention, thereby driving down its cost to near marginal cost. In order for the patent holder to consent to the buyout, the purchase price of the buyout must be at or above the patent holder's expected profits from the patent. ${ }^{178}$

Despite their conceptual appeal and perennial attention in the scholarly literature, true patent buyouts seem rare, or perhaps altogether extinct. The U.S. government does not appear to have purchased and taken title to any privately held patent in the last sixty years. ${ }^{179}$

Nevertheless, some commentators have proposed patent buyouts as a COVID-19 response to ensure widespread access to therapeutics while preserving traditional patent incentives. Hemel

177 Michael R. Kremer, Patent Buyouts: A Mechanism for Encouraging Innovation, 113 Q.J. ECON. 1137, 1138 (1998) (explaining how the government of France purchased the patent for Daguerreotype photography in 1839 and then placed it in the public domain).

${ }^{178}$ See id. (proposing that the government "buy out patents at [their] private value times a fixed markup that would roughly cover the difference between the social and private values of inventions").

${ }^{179}$ Michael Kremer's influential 1998 paper discusses nineteenth century patent buyouts in France, England, and several U.S. states, but it provides no modern example of a U.S. government patent buyout. $I d$. at 1144 . Kremer points out that "[t]he United States Patent Compensation Board compensates developers of innovations of military value relating to atomic energy," but does not provide examples. $I d$. at 1145 . The most recent example we have been able to find of the U.S. government purchasing or otherwise compensating an inventor for an atomic energy patent is in 1953, when the Atomic Energy Commission purchased U.S. Patent No. 2,206,634, entitled "Process for the production of radioactive substances," from a group of inventors that included Enrico Fermi. See Simon Turchetti, "For Slow Neutrons, Slow Pay": Enrico Fermi's Patent and the U.S. Atomic Energy Program, 1938-1953, 97 IsIs 1, 2 (2006). Hemel and Ouellette describe the U.S. government's Medicaid program as "[t]he closest thing to a large-scale patent buyout scheme in the United States." Hemel \& Ouellette, supra note 167, at 594. But Medicaid and other federal programs under which the U.S. government purchases authorized copies of prescription drugs and medical devices at full or near-full price differ significantly from true patent buyouts, not least because the government's purchases of patented products under Medicaid transfer no patent rights to the government and do not empower the government to manufacture those products itself, nor to authorize competitor manufacturers to do so. 
and Ouellette suggest that the United States and others could "offer strong incentives to drugmakers while ensuring affordability by committing to patent buyouts for effective treatments." ${ }^{180}$ Kominers has similarly proposed that the U.S. government "could purchase medical-device patents and then place them in the public domain," which would "free manufacturers-with coordination from government - to produce those devices and meet soaring demand" during the COVID-19 crisis. $^{181}$

\section{Government Patent Use Under Section 1498}

Today's government patent use statute, codified at 28 U.S.C. $\S 1498(\mathrm{a})$, opens as follows:

Whenever an invention described in and covered by a patent of the United States is used or manufactured by or for the United States without license of the owner thereof or lawful right to use or manufacture the same, the owner's remedy shall be by action against the United States in the United States Court of Federal Claims for the recovery of his reasonable and entire compensation for such use and manufacture. ${ }^{182}$

The statute goes on to make clear, based on the World War II amendments noted earlier, 183 that federal contractors, subcontractors, and other authorized agents are immune to infringement liability where they have "authorization and consent of the Government."184

The nature of "reasonable and entire compensation" under the statute is worth some discussion. ${ }^{185}$ The Supreme Court has historically emphasized the "comprehensive character of the remedy provided" under the law. ${ }^{186}$ Courts have interpreted the statute

${ }^{180}$ Hemel \& Ouellette, supra note 31.

${ }^{181}$ Scott Duke Kominers, Patent Protection Should Take a Backseat in a Crisis, BLOOMBERG (Mar. 26, 2020), https:/www.bloomberg.com/opinion/articles/ 2020-03-26/patent-protection-should-take-backseat-in-coronavirus-crisis.

$182 \S 1498(a)$.

183 See supra note 94.

184 See 28 U.S.C. § 1498(a); Madey v. Duke Univ., 307 F.3d 1351, 1359 (Fed. Cir. 2002).

185 For more comprehensive discussions of compensation under $\S 1498$, see generally Brennan et al., supra note 11, at 310; Cahoy 2011, supra note 2; Cahoy 2002, supra note 26.

186 Richmond Screw Anchor Co. v. United States, 275 U.S. 331, 343 (1928). 
generally to call for a reasonable royalty rather than other remedies. ${ }^{187}$ Lost profits may be available "only after the strictest proof that the patentee would actually have earned and retained those sums in its sales to the Government"; ${ }^{188}$ value to the government is rarely the standard. ${ }^{189}$ Any royalty is premised upon a nonexclusive license adequate to cover the goods and services procured or authorized by the government, rather than the value of an exclusive license or total appropriation of the patent. ${ }^{190}$

Belying the perception that government patent use is "stealing," "expropriation," a "nuclear option," or the like, ${ }^{191}$ surveys of past $\S 1498$ cases confirm that reasonable royalty awards under $\S 1498$ are "generally provided at a market rate," 192 such that the reasonable royalty paid for government patent use is similar to compensation for private infringement calculated using the standard factors of Georgia-Pacific Corp. v. U.S. Plywood Corp. ${ }^{193}$ Royalty awards under $\S 1498$ may, and often do, account for a patent holder's risk-

187 See Hughes Aircraft Co. v. United States, 86 F.3d 1566, 1573 (Fed. Cir. 1996); Decca Ltd. v. United States, 640 F.2d 1156, 1169 \& n.22 (Ct. Cl. 1980) (citing Tektronix, Inc. v. United States, 552 F.2d 343, 349 (Ct. Cl. 1977)); Brennan et al., supra note 11, at 313; Cahoy, supra note 26, at 156-57; Mitchell, supra note 27, at $542-43$.

188 Tektronix, 552 F.2d at 349; accord Leesona Corp. v. United States, 599 F.2d 958, 970-71 (Ct. Cl. 1979); see also Brennan et al., supra note 11, at 311 (“ '[L]ost profits' are strongly disfavored, and perhaps entirely unavailable, under $\S 1498$.”); Cahoy, supra note 26, at 155 ("[L]ost profits have apparently been out of reach to plaintiffs in $\S 1498$ actions since the mid-1930s.”).

${ }^{189}$ See Leesona, 599 F.2d at 971; Decca, 640 F.2d at 1167 n.20.

190 See Motorola, Inc. v. United States, 729 F.2d 765, 768 n.3 (Fed. Cir. 1984) (describing government as "a compulsory, nonexclusive licensee").

191 See supra notes 2-13.

192 Cahoy, supra note 2, at 491; see also Bendix Corp. v. United States, 676 F.2d 606, 609 (Ct. Cl. 1982) (Federal Circuit's predecessor court describing "awards against the private infringer, and against the government taker," as "similar"); 7 DONALD S. CHISUM, CHISUM ON PATENTS § 20.03 (2020) (describing $§ 1498$ compensation as "construed and applied in a fashion similar to the measure of compensatory damages in suits against infringers other than the United States"); Laura Burson et al., Suing for Patent Infringement if the Government Takes Your Intellectual Property During the COVID-19 Pandemic, IPWATCHDOG (Apr. 24, 2020), https://www.ipwatchdog.com/2020/04/24/suing-patent-infringementgovernment-takes-intellectual-property-covid-19-pandemic/id=120922 (noting the use of "hypothetical negotiation" under Georgia-Pacific Corp. v. U.S. Plywood Corp. to assess $\S 1498$ damages).

193318 F. Supp. 1116, 1120 (S.D.N.Y. 1970), rev'd on other grounds, 446 F.2d 295 (2d Cir. 1971). 
adjusted investments in research and development. ${ }^{194}$ In other words, government patent use will generally not "represent a discount from the market price of the licensed good" unless the patentee's expectations are excessive; ${ }^{195}$ the public value of $\S 1498$ may instead be accuracy and objectivity of compensation. As a result, Cahoy observes that, rather than being "disruptive," government patent use and $\S 1498$ "can fit within the broader goals of the intellectual property system, encouraging fair and intelligent pricing, and supporting access. ${ }^{~} 196$ Government patent use does not dramatically undercompensate patent holders and, as such, need not upset patent holders' investments or incentives to innovate (although the timing of compensation under $\S 1498$ is delayed, as we discuss below $^{197}$ ).

One way of understanding the operation of $\S 1498$ is through the distinction between "property rules," where the price of an entitlement is subjectively set by the holder, and "liability rules," where the price is set by an independent adjudicator. ${ }^{198}$ Patents are

${ }^{194}$ See Tektronix, Inc. v. United States, 552 F.2d 343, 350 (Ct. Cl. 1977) (noting relevance of patentee "which took the risks and bore the expense of developing the [invention] and creating a market for them"); Brennan et al., supra note 11, at 314. Numerous scholars have suggested that royalties of $10 \%$ or less of the infringers' sales are common in $\S 1498$ cases, and that royalties of over $10 \%$ are rare. See Brennan et al., supra note 11, at 310; Kapczynski \& Kesselheim, supra note 15, at 793 ("Royalties are commonly set at 10 percent of sales or less" in $\S 1498$ cases involving the Department of Defense); Richard J. McGrath, The Unauthorized Use of Patents by the United States Government or Its Contractors, 18 AIPLA Q.J. 349, 352 (1991) ("Historically, the highest royalty rate that the United States Claims Court has awarded is $10 \%$."); see also JAMES LOVE, WHO, REMUNERATION GUIDELINES FOR NON-VOLUNTARY USE OF A PATENT ON MEDICAL TECHNOLOGIES 18 (2005), https://apps.who.int/iris/handle/10665/ 69199 (same). While we are not aware of a court-ordered royalty under $\S 1498$ of more than $10 \%$ of the revenues associated with the government's use-e.g., the sales revenues of a contractor authorized under $\S 1498$ - reasonable royalties calculated under the Georgia-Pacific factors in routine patent infringement suits under 35 U.S.C. § 271 sometimes exceed 10\%. See 4 ROBERT A. MATTHEWS, JR., ANNOTATED PATENT DIGEST §§ 30:107-30:110 (2019) (documenting reasonable royalties in recent $\S 271$ cases of greater than $10 \%$ of the infringers' sales revenues, e.g., $14.5 \%, 17.5 \%$, and $32 \%$ ). It seems to us that the same may be true in future litigation under $\S 1498$.

${ }^{195}$ Cahoy, supra note 2, at 494.

${ }^{196} \mathrm{Id}$.

${ }^{197}$ See infra Part III.A.3.

${ }^{198}$ See Guido Calabresi \& A. Douglas Melamed, Property Rules, Liability Rules, 
ordinarily treated under a property rule, insofar as courts and administrative tribunals may issue injunctions that prevent wouldbe infringers from using a patented invention without the voluntary consent of the patent holder. ${ }^{199}$ While the desirability of applying a property rule to patents is a topic of much debate, ${ }^{200}$ it has been long recognized that injunctive relief is inappropriate where access to a patented invention is necessary for public health or safety. ${ }^{201}$ Section 1498 can thus be understood to give the U.S. government discretion to waive the property rule remedy of patent injunctions in appropriate situations.

Government patent use under $\S 1498$ should be distinguished from several other forms of public and private ordering of patent interests. First, it is entirely distinct from arrangements involving socalled "FRAND" licenses. The latter concept relates to patentholder obligations to license certain patents on "Fair, Reasonable, and Non-Discriminatory" terms, arising either out of a private commitment to do $\mathrm{so}^{202}$ or to satisfy a government regulation or

and Inalienability: One View of the Cathedral, 85 HARV. L. Rev. 1089, 1092 (1972).

${ }^{199}$ See Tariff Act of $1930 \S 337$ (d)(1), 19 U.S.C. $§ 1337$ (as amended); 35 U.S.C. $\S 283$. In private patent infringement disputes, liability rather than property rules often prevail, as courts frequently decline to order injunctive relief under the Supreme Court's test in eBay Inc. v. MercExchange, LLC. See 547 U.S. 388, 391 (2006). See Christopher B. Seaman, Permanent Injunctions in Patent Litigation After eBay: An Empirical Study, 101 IowA L. REv. 1949, 1984 (2016). Such circumstances are somewhat less common with respect to pharmaceutical patents, because courts tend to award injunctions to bona fide operating manufacturers. See id. at 1988-90.

${ }^{200}$ See Colleen V. Chien \& Mark A. Lemley, Patent Holdup, the ITC, and the Public Interest, 98 CORNELL L. REV. 1 (2012); Daniel A. Crane, Intellectual Liability, 88 TeX. L. ReV. 253, 255-56 (2009); Mark A. Lemley \& Philip J. Weiser, Should Property or Liability Rules Govern Information?, 85 TEX. L. REV. 783, 784 (2007); Doug Lichtman, Patient Patents: Can Certain Types of Patent Litigation Be Beneficially Delayed?, 46 J. LEGAL STUD. 427 (2017); Carl Shapiro, Injunctions, Hold-Up, and Patent Royalties, 12 AM. L. \& ECON. REV. 280, 308 (2010); Katherine J. Strandburg, Patent Fair Use 2.0, 1 U.C. IRVINE L. REV. 265, 278 (2011). See generally Seaman, supra note 199, at 1956-58 \& nn.33-49 (citing sources and reviewing arguments).

${ }^{201}$ See, e.g., Rite-Hite Corp. v. Kelley Co., 56 F.3d 1538, 1547-48 (Fed. Cir. 1995) (citing examples); Seaman, supra note 199, at 1962, 1991.

202 Patent owners may commit to FRAND licensing in order to have their technologies adopted into privately developed technical standards such as Wi-Fi or mobile communications systems. See generally Jorge L. Contreras, A Brief 
benefit condition. ${ }^{203}$ While FRAND arrangements also overcome the property rule of patent remedies and indeed often enlist a court to do so, the computation of such royalties is idiosyncratic and subject to rules different from the traditional Georgia-Pacific factors. ${ }^{204}$

Additionally, government patent use under $\S 1498$ is distinct from the Defense Production Act (DPA). ${ }^{205}$ The DPA, enacted at the start of the Korean War ${ }^{206}$ and since expanded, ${ }^{207}$ permits the U.S. government to take effective control of manufacturing when doing so is "necessary or appropriate to promote the national defense," 208 broadly defined. ${ }^{209}$ The DPA also includes a variety of powers "to help ensure that the nation has an adequate supply of, or the ability to produce, essential materials and goods necessary for the national defense." ${ }^{\prime 210}$ This makes the DPA complementary to $\S 1498$, in that

History of FRAND: Analyzing Current Debates in Standard Setting and Antitrust Through a Historical Lens, 80 ANTITRUST L.J. 39, 42 (2015); Herbert Hovenkamp, FRAND and Antitrust, 105 CORNELL L. REV. 1683 (2020); Mark A. Lemley \& Timothy Simcoe, How Essential Are Standard-Essential Patents?, 104 CORNELL L. REV. 607, 610 (2019).

${ }^{203}$ See, e.g., 21 st Century Cures Act: Interoperability, Information Blocking, and the ONC Health IT Certification Program, 85 Fed. Reg. 25642, 25960-61 (May 1,2020 ) (to be codified at 45 C.F.R. $§ 171.303$ ) (requiring licensing of certain electronic health record technology on "reasonable" and "non-discriminatory" terms); AT\&T Commc'ns of Va., Inc. v. Bell Atl.-Va., Inc., 197 F.3d 663, 670-71 (4th Cir. 1999) (holding telecommunications statute requiring "access to network elements" on terms that are "reasonable and nondiscriminatory," 47 U.S.C. § 251, to require provider "to renegotiate its existing intellectual property licenses"); Narechania, supra note 1, at 1517-23.

${ }^{204}$ See Microsoft Corp. v. Motorola, Inc., 795 F.3d 1024, 1041-42 (9th Cir. 2015); Ericsson, Inc. v. D-Link Sys., Inc., 773 F.3d 1201, 1230-32 (Fed. Cir. 2014).

${ }^{205}$ Defense Production Act of 1950, 50 U.S.C. $\S \S 4501-4568$.

${ }^{206}$ Defense Production Act of 1950, Pub. L. No. 81-774, 64 STAT. 798.

${ }^{207}$ See J. Michael Littlejohn, Using All the King's Horses for Homeland Security: Implementing the Defense Production Act for Disaster Relief and Critical Infrastructure Protection, 36 PUB. CONT. L.J. 1, 3-4 (2006) (tracing gradual expansion of the DPA).

20850 U.S.C. $\$ 4511(\mathrm{a})$.

${ }^{209} \S 4552(14)$ (defining "national defense" to encompass "programs for military and energy production or construction, military or critical infrastructure assistance to any foreign nation, homeland security, stockpiling, space, and any directly related activity").

${ }^{210}$ Michael H. Cecire \& Heidi M. Peters, Cong. Research SerV., Report No. R43767, The Defense Production ACt OF 1950: History, Authorities, AND CONSIDERATIONS FOR CONGRESS 9, https://fas.org/sgp/crs/natsec/R43767.pdf; 
the former can force a firm to engage in certain manufacturing, while the latter removes patent-infringement barriers to that manufacturing. ${ }^{211}$ But the U.S. government can use patents under $\S 1498$ without invoking the DPA, and government patent use is, in many ways, a milder intervention than coordinated production under the DPA. For example, if a manufacturer refuses to sell a particular patented product to the U.S. government, the government might choose to procure the product from a competitor authorized under $\S 1498$, or it might instead choose to invoke the DPA and compel the manufacturer's own factories to supply the government. The government patent use option would protect the manufacturer's existing contracts and business relationships; the DPA option would upend them.

Finally, $\S 1498$ must be distinguished from eminent domain, or takings, under the Fifth Amendment. The Federal Circuit recently reaffirmed this distinction in Golden v. United States, holding that "a patent owner may not pursue an infringement action as a taking under the Fifth Amendment," because patent infringement actions against the U.S. government "sound in tort and are to be pursued exclusively under 28 U.S.C. $§ 1498 . " 212$ The court deemed this

see also James A. Durham, The Present Status of Price Control Authority, 52 Colum. L. REV. 868 (1952); Littlejohn, supra note 207; Note, The Defense Production Act: Choice as to Allocations, 51 ColuM. L. REV. 350 (1951).

211 See Rick Longton et al., Intellectual Property Considerations for Manufacturers Contracted Under the Defense Production Act, CovingTon \& BURLING LLP 2 (Apr. 2, 2020), https://www.cov.com/en/news-and-insights/ insights/2020/04/intellectual-property-considerations-for-manufacturers-

contracted-under-the-defense-production-act. The DPA alone likely cannot affect patents. See Defense Production Act of 1950: Hearing on H.R. 9176 Before the H. Comm. on Banking and Currency, 81st Cong. 35 (July 24-25, 1950), https:// catalog.hathitrust.org/Record/102432877 (testimony of Mr. Kendall, National Security Resources Board).

212955 F.3d 981, 987-88 (Fed. Cir. 2020). While Golden did not answer the question of whether application of $\S 1498$ itself is an eminent domain action, the opinion is irreconcilable with that view in describing government patent use as sounding in tort. Golden further repeatedly approves of Zoltek I, which squarely rejected $\S 1498$ being an eminent domain statute. See Zoltek I, 442 F.3d 1345, 1352 (Fed. Cir. 2006) (per curiam) ("Had Congress intended to clarify the dimensions of the patent rights as property interests under the Fifth Amendment, there would have been no need for the new and limited sovereign immunity waiver [of the 1910 Act].”), vacated, 672 F.3d 1309 (Fed. Cir. 2012) (en banc), cited with approval in Golden, 955 F.3d at 987-88. The Supreme Court denied certiorari in Golden in December 2020. Golden v. United States, No. 20-5532, 2020 WL 7132384 (U.S. Dec. 7, 2020). 
holding "mandate[d]" by the Supreme Court's decision in Schillinger that patent infringement could not be remedied as a taking. ${ }^{213}$ Eminent domain may serve as a helpful analogy for government patent use, but it is a distinct act. ${ }^{214}$ Indeed, outright government condemnation of patents was historically contemplated with regard to aviation technology ${ }^{215}$ and commentators have called for the government to invoke eminent domain on patents, ${ }^{216}$ but condemnation has distinctly different consequences from government patent use: In the former case but not the latter, the owner of the condemned patent loses the ability to license the patent to third parties and indeed may lose the ability to practice the invention at all. ${ }^{217}$ To be sure, a substantial line of Supreme Court and other cases describe $\S 1498$ in terms of eminent domain, ${ }^{218}$ as do multiple commentators. ${ }^{219}$ But, as Masur and Mortara observe from review of those $\S 1498$ cases, those judicial statements have consistently been in dicta with "no effect whatsoever on the success or failure of the claims"; in other words, government patent use "is described in terms of eminent domain or takings when that characterization is irrelevant to the resolution of the case at hand."220

${ }^{213}$ Golden, 955 F.3d at 988.

${ }^{214}$ See, e.g., Brennan et al., supra note 11, at 307-09.

215 See supra notes 55-61.

216 See, e.g., Kesselheim \& Avorn, supra note 126, at 435; Mitchell, supra note 27, at 548-49 (distinguishing takings of patents from $\S 1498$ ); $c f$. Fran Quigley, Tell Me How It Ends: The Path to Nationalizing the U.S. Pharmaceutical Industry, 53 U. MICH. J.L. REFORM 755, 804-05 (2020) (suggesting that seizure of patents may not require significant Fifth Amendment compensation).

217 As one of us has noted, the government could use intellectual property condemnation as a mechanism for suppressing information, with obvious and troubling consequences for speech interests. See Charles Duan, Copyright Law Could Stop 3-D Printed Guns. Should It?, LAWFARE (Aug. 31, 2018), https:// www.lawfareblog.com/copyright-law-could-stop-3-d-printed-guns-should-it. Government patent use cannot effect this result.

218 See, e.g., James v. Campbell, 104 U.S. 356, 358 (1882); Leesona Corp. v. United States, 599 F.2d 958, 964-65 (Ct. Cl. 1979). Contra De Graffenried v. United States, 29 Fed. Cl. 384, 387 (1993) ("[T] he far more compelling argument is that Section 1498(a) actions are not 'eminent domain proceedings' ....”); Charles Pfizer \& Co., 39 Comp. Gen. 760, 763 (1960) ("Clearly, [the 1910] act is an amendment to the patent laws and restricts the rights of a patentee by providing for government use of patents ....").

219 See sources cited supra note 20.

${ }^{220}$ Masur \& Mortara, supra note 20, at 990-92. James provides a striking example: The Court digresses for a page and a half on the takings nature of 


\section{Section 1498 As Policy Tool in a National EMERGENCY}

The history and nature of $\S 1498$ suggest a useful framework for weighing the role of government patent use, in national emergencies and otherwise. In particular, we discern four generally underappreciated features of $\S$ 1498: (1) speed, (2) flexibility, (3) ex post determination of the appropriate compensation (occurring not only after not only invention but after the government's use), and (4) determination of that compensation by an impartial adjudicator. The salience of these four factors to any particular situation, in our view, is indicative of whether $\S 1498$ will likely be advantageous in that situation over other tools such as patent buyouts for ensuring access to critical technologies. That is not to say that $\S 1498$ is always preferable to, or should be used to the exclusion of other innovation policy tools; it is instead a complement that can be freely mixed and matched with the others when appropriate. ${ }^{221}$

These features of $\S 1498$ do not depend on the presence of a national emergency, and we do not find the existence of emergency conditions to be a prerequisite to use of $\S 1498$. Besides the obvious difficulties in defining national emergencies, ${ }^{222}$ the identified advantages of $\S 1498$ can be relevant to plainly non-emergency situations. The flexibility of government patent use, for example, can be highly relevant to the operations of financial markets. ${ }^{223}$ Furthermore, we intend this analysis to be one of sufficiency rather than necessity: Where none of these advantages is especially salient, use of $\S 1498$ may still be warranted, but that use could be justified on other factors outside of the scope of the present analysis, such as deadweight loss from monopoly pricing ${ }^{224}$ or human rights. ${ }^{225}$

government patent use, only to then flatly note that "the conclusion which we have reached in this case does not render it necessary to decide this question." 104 U.S. at 357-59.

${ }^{221}$ For an analysis of intellectual property's two distinct elements-innovation incentive and allocation mechanism-and the ways in which patent-based innovation incentives and allocation mechanisms can be mixed and matched with other incentives and mechanisms, such as tax credits and prizes, see Hemel \& Ouellette 2019, supra note 167, at 563-74.

${ }^{222}$ Cf. Youngstown Sheet \& Tube Co. v. Sawyer, 343 U.S. 579, 646-47 (1952) (Jackson, J., concurring) (describing "[1] oose and irresponsible use of adjectives" such as "emergency," "without fixed or ascertainable meanings").

${ }^{223}$ See infra note 232 (describing use of $\S 1498$ for check clearing transactions).

224 See Brennan et al., supra note 11, at 317-18.

${ }^{225}$ See Cahoy, supra note 2, at 500-07. 
That these features have indeed been salient in past national crises shows that $\S 1498$ will continue to be an advantageous and sometimes indispensable policy tool. Indeed, as we describe below, the advantages of $\S 1498$ are highly relevant to COVID-19 technologies, including diagnostic tests, ventilators, and medical treatments. ${ }^{226}$ To highlight these advantages and their relevance, we develop a roadmap for one use case today: ensuring adequate and affordable access to remdesivir, an antiviral drug that has shown promise as a treatment for COVID-19. Our roadmap illuminates the four underappreciated features of $\S 1498$ and highlights how government patent use can protect public health, patent holders, and the public purse.

\section{A. Four Key Features of Government Patent Use in a National Emergency}

\section{Speed}

Government patent use is quick - a feature particularly valuable in a national emergency. The U.S. government can exercise its powers under $\S 1498$ instantly, without any procedure-not even notice to the holder of patent rights in the product being used or manufactured by the government. ${ }^{227}$ (In this regard, "election" or "invocation" of government patent use are perhaps the wrong terms to use - the U.S. government's power to use privately held patents is always on, by default. ${ }^{228}$ )

${ }^{226}$ A comment that applies to all of Section IV: this Article was researched and written in the spring and summer of 2020 and edited in the fall of 2020. The COVID-19 pandemic is fast-changing, but we have done our best to ensure that the facts herein were accurate as of mid-September 2020.

${ }^{227}$ According to the 1995 Resource Book published by the United Nations Conference on Trade and Development (UNCTAD) and International Centre on Trade and Sustainable Development (ICTSD) on the Agreement on Trade-Related Aspects of Intellectual Property Rights (TRIPS), "under U.S. law, the government may use any patented invention (or authorize its contractor to use such invention) without providing prior notification to the patent holder, subject only to the patent holder's right to initiate a proceeding before the Court of Claims for compensation." UNITED NATIONS CONFERENCE ON TRADE \& DEV. \& INT'L CTR. fOR TRAde \& Sustainable DeV., Resource BoOK ON TRIPS AND DEVELOPMENT 468 (2005); see also Cahoy, supra note 2, at 494 (observing that "the U.S. essentially engages in" "compulsory licensing without negotiation").

${ }^{228}$ In this respect, the U.S. government's patent rights under § 1498 differ fromand are more powerful and versatile than-its march-in rights under the BayhDole Act. See 35 U.S.C. § 203(a). To exercise march-in rights and issue a compulsory license on a Bayh-Dole patent, a federal agency must first make a 
Indeed, the U.S. government can exercise its rights under $\S 1498$ unwittingly-for example, if it unknowingly purchases products from a supplier that turn out to be covered by another party's patents. ${ }^{229}$ Section 1498 even arguably enables the government to absolve third parties of their liability for past acts of infringement: $\S 1498$ applies to acts performed (1) "by or for" the government and (2) with the government's "authorization or consent." ${ }^{230}$ In Advanced Software Design Corp. v. Federal Reserve Bank of St. Louis, the Federal Circuit recognized that private activity that confers "significant benefits to the United States" satisfies the "by and for" the government prong of the test, and "post hoc" consent by the government can constitute the requisite "authorization or consent." 231 This absolution can be achieved quickly — in the same case, a Treasury official simply sent a letter to the infringer, confirming that the U.S. government condoned the infringer's use of the patented technology. ${ }^{232}$

Government patent use's instantaneity is particularly valuable

determination that certain statutory conditions have been met, such as a determination that public "health or safety needs ... are not reasonably satisfied by the [patent rights-holding] contractor, assignee, or their licensees." $§ 203(a)(2)$. No such determination is necessary under $\S 1498$.

${ }^{229}$ See supra notes 114-117 and accompanying text. A 1958 opinion of the United States Comptroller General acknowledged as much, and seems indeed to actively encourage a kind of willful blindness on the part of U.S. government procurement officers: "[Section 1498] is not consistent with any duty on the part of a contracting agency of the Government to protect the interests of patentees or licensees with respect to articles which it proposes to purchase, since the statute itself defines and provides an exclusive remedy for enforcement of the patentee's rights as to the Government." Herbert Cooper, 38 Comp. Gen. 276, 278 (1958). This opinion appears to remain in effect and govern U.S. government procurement even today, despite substantial efforts to undo the decision legislatively across the 1960s. See Motorola, Inc. v. United States, 729 F.2d 765, 771 (Fed. Cir. 1984); Brennan et al., supra note 11, at 305; Mossinghoff \& Allnutt, supra note 24, at 16-27 (describing legislative reform proposals).

$230 \S 1498(a)$.

231583 F.3d 1371, 1376-79 (Fed. Cir. 2009). In Advanced Software, the patented technology was a method of detecting fraudulent bank checks, and the "significant benefits" to the United States that met the "by and for" the government prong of the test was reduced fraud and financial benefits to the Federal Reserve Banks, as well as to private banks. Id. at 1373, 1378; see also Brennan et al., supra note 11, at 332-33 (reviewing case law on "authorization and consent").

232 See Advanced Software, 583 F.3d at 1377; see also Madey v. Duke Univ., 413 F. Supp. 2d 601, 608 (M.D.N.C. 2006) ("§ 1498 does not require the authorization to take any specific form."). 
when the government must move quickly to disseminate patented products needed to combat a national crisis. By contrast, a patent buyout with even a willing, good faith patent holder could take weeks to negotiate-weeks the government and the American public may not have to spare. ${ }^{233}$ Moreover, the government may not know all the patents that cover a particular product, and thus it may not know which patents it needs to buy, and from whom. For example, as of writing, many different firms are now developingand likely patenting - new ventilator designs designed to protect the lungs of COVID-19 patients. In April 2020, CNET reported that "newly designed, cutting-edge ventilators may be on the way from the likes of tech giant Dyson, General Motors, MIT and a British consortium led by Airbus." ${ }^{234}$ In situations like this, a wide-ranging search of active patents and full-fledged "clearance" study (also known as a "freedom to operate" study) by the government would be necessary to identify all relevant patents and their owners before the government could confidently undertake buyout negotiations. Even a single study on a single product can be "time-consuming and costly.",235

In practice, the government may choose to try to negotiate a buyout or other deal first, in the same way that the government negotiated royalty rates with the Manufacturers' Aircraft Association in 1918 and HHS negotiated the Cipro deal in 2001. Section 1498 nevertheless serves as an important backstop: it prevents "hold-up" or "hold-out" situations where a single patent holder demands a buyout far in excess of the investment costs for developing the invention and a "reasonable" profit. ${ }^{236}$ Hold-ups can occur even in times of national emergency, as occurred in 2001's anthrax scare, when Bayer initially refused to budge on the price of

\footnotetext{
${ }^{233}$ The same defect seems true of auctions, which Kremer proposes as a mechanism to elicit the market value of patents purchased by the government in patent buyouts. See Kremer, supra note 177, at 1146-48.

${ }^{234}$ Jackson Ryan, In the War Against Coronavirus, One Device Can Be the Difference Between Life and Death, CNET (Apr. 3, 2020), https://www.cnet.com/ features/coronavirus-ventilators-why-one-machine-is-pivotal-in-the-battleagainst-covid-19.

${ }^{235}$ See Linda J. Thayer, When is a Freedom to Operate Opinion Cost-Effective?, FINNEGAN (March 2013), https://www.finnegan.com/en/insights/articles/whenis-a-freedom-to-operate-opinion-cost-effective.html.

${ }^{236}$ See Brennan et al., supra note 11, at 309.
} 
ciprofloxacin until HHS threatened to use $\S 1498 .{ }^{237}$ Hold-ups are socially harmful, as they cause delay and inefficient public overspending on the patented technology. ${ }^{238}$ Indeed, there may be hold-up situations that delay, even derail, dissemination of needed patented products to the public that arise not from any intentional gamesmanship on the part of the patent holder but simply from the patent holder's genuine overvaluation of its own patent. If there is no zone of agreement between the patent holder and the government - if the patent holder's reserve price exceeds the government's willingness or ability to pay-then no buyout deal will ever be reached.

\section{Flexibility}

Government patent use under $\S 1498$ can be used flexibly, in numerous ways. We highlight two here.

(a) "Surgical strikes" to expand supply and relieve shortages. Section 1498 is particularly well-suited to relieve limits on production and supply created by patents, especially in times of national emergency. In past emergencies of infectious disease, for example, suppliers that hold patents on important technologies have been unable to keep up with demand, even while they have declined to license their patents to competitor manufacturers. The story of Bayer and ciprofloxacin (Cipro), told above, is one vivid instance. ${ }^{239}$ Roche and oseltamivir (Tamiflu) is another; in 2005, a global outbreak of avian flu led to a spike of demand in the United States and around the world. ${ }^{240}$ Roche's own manufacturing capacity was

${ }^{237}$ See supra Part I.D; see also Leslie Wayne \& Melody Petersen, A Muscular Lobby Rolls Up Its Sleeves, N.Y. TIMES (Nov. 4, 2001), https://www.nytimes.com/ 2001/11/04/business/a-muscular-lobby-rolls-up-its-sleeves.html (reporting that, to the pharmaceutical industry, "any threats to [patent] protection, even at a time of national crisis, is a clarion call to action" and that Bayer initially refused to give the U.S. government any discount on large-scale purchases of ciprofloxacin).

${ }^{238}$ See Brennan et al., supra note 11, at 309-10.

${ }^{239}$ See supra Part I.D.

${ }^{240}$ See CONG. RESEARCH SERV., supra note 162, at 2-3. Somewhat ironically, independent researchers later uncovered clinical trial data (which Roche had withheld from the medical literature) revealing that the billions of dollars spent on oseltamivir by governments around the world were largely wasted: oseltamivir failed to prevent the spread of the flu, reduce hospital admissions, or minimize complications significantly. See Richard Van Noorden, Report Disputes Benefit of Stockpiling Tamiflu, NATURE News \& COMMENT (Apr. 10, 2014), http://www. nature.com/news/report-disputes-benefit-of-stockpiling-tamiflu-1.15022 (citing 
unable to meet demand, but Roche declined to license its patents to Cipla, saying it "fully intend[ed] to remain the sole manufacturer of Tamiflu." ${ }^{241}$ This led to shortages, to several senators calling for invocation of $\S 1498$, and ultimately to Roche making an "aboutface" and agreeing to multiple licenses. ${ }^{242}$

The same phenomenon - a patent-holding manufacturer apparently unable to meet demand and yet unwilling to voluntarily license its patents - has already occurred in the COVID-19 pandemic. One significant example is the field of anti-COVID-19 therapeutic drugs: Gilead, which holds patents on the COVID-19 treatment drug remdesivir, was unable to meet demand (both within the United States and overseas) and yet (to date) is largely unwilling to license its patents to other manufacturers. We tell the story of remdesivir in detail below and make a case for use of $\S 1498$ to expand supply. ${ }^{243}$

Another example of the phenomenon seems to have occurred in diagnostic testing. The molecular diagnostics company Cepheid has drawn praise for developing what is, as of writing, among the most reliable, sensitive point-of-care diagnostic tests for COVID-19, sold under the Xpert Xpress SARS CoV-2 brand name. ${ }^{244}$ These tests

Tom Jefferson et al., Neuraminidase Inhibitors for Preventing and Treating Influenza in Adults and Children, in 2014 COCHRANE DATABASE SySTEMATIC REVIEWS, https://doi.org/10.1002/14651858.CD008965.pub4). Oseltamivir does appear, however, to shorten some symptoms. See What You Should Know About Flu Antiviral Drugs, CTRS. FOR DISEASE CONTROL \& PREVENTION (last visited Nov. 13, 2020), https://www.cdc.gov/flu/treatment/whatyoushould.htm.

${ }^{241}$ See Donald G. McNeil Jr., Indian Company to Make Generic Version of Flu Drug Tamiflu, N.Y. TIMES (Oct. 14, 2005), https://www.nytimes.com/2005/10/14/ health/indian-company-to-make-generic-version-of-flu-drug-tamiflu.html.

${ }^{242}$ Sabin Russell, About-Face on Influenza Drug / Manufacturer Says It Will Consider Licensing Tamiflu, S.F. ChrON. (Oct. 19, 2005), https://www.sfgate. com/health/article/About-face-on-influenza-drug-Manufacturer-says2575819.php; see CONG. RESEARCH SERV., supra note 162, at 13-14.

${ }^{243}$ See infra Part III.B.

${ }^{244}$ See Bruce Japsen, FDA Approves More "Rapid” COVID-19 Coronavirus Tests for Use on Frontlines, FORBES (Mar. 24, 2020), https://www.forbes.com/sites/ brucejapsen/2020/03/24/us-approves-more-rapid-covid-19-tests-for-use-onfrontlines/ (describing FDA's emergency use authorization for the Xpert Xpress SARS CoV-2); Giorgia Guglielmi, The Explosion of New Coronavirus Tests That Could Help to End the Pandemic, NATURE (July 17, 2020), https://www.nature. com/articles/d41586-020-02140-8 (explaining that Cepheid's test "take[s] less than one hour to perform"); Rachana Pradhan, As Problems Grow with Abbott's 
provide results in less than hour, making them particularly useful in hospitals and other "point-of-care" locations where rapid results are needed to provide appropriate medical care. HHS has spent millions in public money to purchase Cepheid's test machines through the Strategic National Stockpile for public health emergencies ${ }^{245}$ and distribute them to hospitals in need. ${ }^{246}$ Each Xpert Xpress SARS CoV-2 test uses a single disposable plastic cartridge, pre-filled with the appropriate chemicals to run the test. ${ }^{247}$ Cepheid has struggled to manufacture and distribute enough of the disposable cartridges tests to meet demand through the summer of $2020 .^{248}$

A third example of shortages of (presumably) patented antiCOVID technologies has occurred with personal protective equipment (PPE). In the spring of 2020, 3M's patented N95 respirators were widely demanded by health care providers across

Fast COVID Test, FDA Standards Are Under Fire, KAISER HEALTH NEWS (June 22, 2020), https://khn.org/news/abbott-rapid-test-problems-grow-fda-standardson-covid-tests-under-fire/ (describing Cepheid's test as more accurate than a competitor's point-of-care test). Cepheid has also drawn some criticism for its pricing. See Press Release, Médecins Sans Frontières Int'1, Cepheid Charging Four Times More than It Should for Coronavirus COVID-19 Tests (July 28, 2020), https:/www.msf.org/diagnostic-company-cepheid-charging-more-it-shouldcovid-19-tests.

245 See FDA standards under fire as problems grow with fast COVID-19 tests, HeAlthCARE PurCHASING NEWS (Jun. 24, 2020), https://www.hpnonline.com/ sourcing-logistics/lab-pharmacy-supply-management/article/21143494/fdastandards-under-fire-as-problems-grow-with-fast-covid19-tests.

246 See Pradhan, supra note 244; Contracts for April 10, 2020, U.S. DEP'T DEF. (Apr. 10, 2020), https://www.defense.gov/Newsroom/Contracts/Contract/Article/ 2146301/ (“Cepheid, Sunnyvale, California, was awarded a \$32,788,420 firmfixed-price contract for the purchase of up to 137 Cepheid GeneXpert instruments, 105 GeneXpert 16s instruments, and up to 472,000 emergency-use-only assays to detect novel coronavirus disease in human clinical samples.").

247 See Michael J. Loeffelholz et al., Multicenter Evaluation of the Cepheid Xpert Xpress SARS-CoV-2 Test, 58 J. CliniCAL MicrobIOLOGY 1, 2 (2020), https://jcm. asm.org/content/58/8/e00926-20.

248 See Lauren Dunn, COVID-19 Tests: There's an Insurmountable Backlog of Virus Tests. A Rapid Test Could Help, NBC NEWs (July 23, 2020), https://www. nbcnews.com/health/health-news/covid-19-tests-there-s-insurmountablebacklog-virus-tests-rapid-n1234622; Craig LeMoult, Hospitals Can't Get Enough COVID-19 Tests, WGBH NEws (Jun. 29, 2020), https://www.wgbh.org/news/ local-news/2020/06/29/hospitals-cant-get-enough-covid-19-tests; see also Joel Rose, Coronavirus Testing Machines Are Latest Bottleneck in Troubled Supply Chain, NPR (May 28, 2020), https://www.npr.org/2020/05/28/863558750/ coronavirus-testing-machines-are-latest-bottleneck-in-troubled-supply-chain (describing shortages of other COVID-19 tests). 
the United States, but the company proved unable to meet demand, leading Governor Beshear of Kentucky to call on 3M to voluntarily license its patents to competitor manufacturers to increase supply. ${ }^{249}$

Shortages of drugs, diagnostic tests, and PPE in the COVID-19 pandemic suggest a valuable use of $\S 1498$ : to break logjams like these and increase supply, and quickly. ${ }^{250}$ Government patent use can be used to make focused "surgical strikes" in places where there is a need to move quickly to expand supply of patented productse.g., supplying COVID-19 diagnostic tests to emerging rural virus hotspots where there is little existing testing capacity. ${ }^{251}$ HHS could, for example, continue to purchase and distribute as many Xpert Xpress SARS CoV-2 cartridges and test machines from Cepheid as the company can manufacture while simultaneously soliciting bids for further supply of diagnostic tests that mimic Cepheid's. Assume that Cepheid holds one or more patents on its tests and can manufacture up to about 500,000 Xpert Xpress test cartridges per week. ${ }^{252}$ Assume further that Cepheid declines to license its patents

${ }^{249}$ See Morgan Watkins, Kentucky Gov. Andy Beshear Calls on $3 M$ to Release Patent for N95 Respirator Amid Pandemic, LOUISVILle COURIER J. (Apr. 3, 2020), https://www.courier-journal.com/story/news/2020/04/03/beshear-calls-3m-release-patent-n-95-respirator-amid-pandemic/5112729002.

${ }^{250} \mathrm{We}$ do not mean to suggest here that patents or other intellectual property protection are the sole source of shortages of goods used against COVID-19. Shortages are caused by a large number of factors - scarcity of raw materials, breakdown in supply chains or distribution systems, customs and regulatory rules, etc. See, e.g., Erin R. Fox et al., Drug Shortages: A Complex Health Care Crisis, 89 MAYO CliniC PROC. 361 (2014), https://doi.org/10.1016/j.mayocp.2013.11. 014. Shortages of simple, presumably off-patent commodities like nasal swabs have also plagued the United States's COVID-19 response. See, e.g., David Lim \& Brianna Ehley, Inside America's Unending Testing Snafu, Politico (Apr. 22, 2020), https://www.politico.com/news/2020/04/22/coronavirus-testing-problemamerica-201372. Our point is simply that whenever a shortage arises from, or is aggravated by, a patent holder's reluctance to voluntarily license its patents and inability to manufacture enough of its patent products to meet demand, government patent use offers a straightforward solution.

${ }^{251}$ Reis Thebault \& Abigail Hauslohner, A Deadly "Checkerboard”: Covid-19's New Surge Across Rural America, WASH. Post (May 24, 2020), https:/www. washingtonpost.com/nation/2020/05/24/coronavirus-rural-america-outbreaks.

252 This was, roughly speaking, the case as of June 2020, when Cepheid anticipated its cartridge manufacturing capacity over the summer of 2020 would be approximately 2 million tests per month (6 million tests per quarter). See Susan Kelly, Cepheid Developing Test to Distinguish COVID-19 from Flu, MEDTECHDRIVE (June 10, 2020), https://www.medtechdive.com/news/cepheiddeveloping-test-to-distinguish-covid-19-from-flu/579524. 
voluntarily to competitor manufacturers (as, so far, it seems to have). National demand for reliable point-of-care COVID-19 tests is, as of writing, running much higher than 500,000 tests per week; some public health experts estimate that the United States must administer millions of tests per day to contain future outbreaks. ${ }^{253}$ Under these circumstances, Cepheid might ordinarily sell its Xpert Xpress test cartridges at a high price to the highest-bidding users as it gradually ramps up its manufacturing capacity, leaving everyone else without access to Cepheid's testing technology, which is purportedly bestin-class. HHS could expand supply more quickly — and deal with the COVID-19 testing crisis plaguing the United States as we writeby invoking $\S 1498$ to enable generic manufacturing even as it continues to buy tests at Cepheid's monopoly price.

The above hypothetical "surgical strike" to increase supply of and expand access to Cepheid's point-of-care diagnostic test for COVID-19 illustrates how the U.S. government can tailor its use of $\S 1498$ to make relatively small interventions in the marketplace and the "normal" operation of patents and patent incentives. Such use of $\S 1498$ would protect Cepheid's investments and expectations, as Cepheid would receive compensation under $\S 1498$ for the government-authorized generic manufacturing in addition to its profits on all of the tests it is able to manufacture and sell at full price. In specific circumstances-even in whole fields of technology - where the U.S. government is particularly concerned about patent holders' investment expectations and incentives for future innovation, such modest interventions with $\S 1498$ may be most appropriate. ${ }^{254}$ The possibility of using $\S 1498$ in this flexible, modest way belies the conventional wisdom ${ }^{255}$ that government patent use is necessarily disruptive.

(b) Shielding beneficial activity from infringement liability. Section 1498 could also be used to shield specific socially useful activities from the threat of unexpected patent infringement liability.

253 See Alexis C. Madrigal \& Robinson Meyer, A Dire Warning From COVID-19 Test Providers, ATLANTIC (June 30, 2020), https://www.theatlantic.com/science/ archive/2020/06/us-coronavirus-testing-could-fail-again/613675. This number includes both rapid point-of-care testing and slower laboratory testing.

${ }^{254}$ See, e.g., Rizzolo et al., supra note 13 (expressing concern over the possibility that exercise of $\S 1498$ on patented anti-COVID-19 drugs could "have a chilling effect on biopharmaceutical research and drug development").

255 See supra notes 3-13. 
For example, in March 2020, a non-practicing entity, Labrador Diagnostics LLC, filed a patent infringement suit seeking injunctive relief against a company whose equipment is used in some COVID19 diagnostic testing, raising concern over the (admittedly remote) possibility that the lawsuit would reduce or delay testing. ${ }^{256}$ As Moss and Harmon of the Electronic Frontier Foundation have argued, HHS could conceivably intervene in situations like this, providing post hoc authorization for the allegedly infringing activity under $\S 1498$ and shifting onto the government any liability for patent infringement, thereby ensuring the activity continues. ${ }^{257}$ Such intervention occurred in Advanced Software, where the Treasury Department retroactively authorized patent-infringing activity. ${ }^{258}$ (This diagnostic testing scenario would satisfy the first prong of Advanced Software's test: a use of patented technology that confers "significant benefits to the United States" constitutes use "by and for" the government, as required by the text of $\S 1498 .{ }^{259}$ "When the government requires private parties to perform quasi-governmental functions, ... there can be no question that those actions are undertaken 'for the benefit of the government." ${ }^{\text {260 }}$ )

Recall that Congress revised $\S 1498$ 's predecessor statute in 1918 and again in 1942 to permit precisely this type of government patent use: protecting and encouraging socially useful third-party activity that is, or might be, patent infringing from the risk of an injunction and monetary liability. ${ }^{261}$ As an appellate panel of the Court of Claims held in 1967 (in a case concerning the Department of Defense's purchase of third-party anti-G suits and valves to prevent military pilots from blacking out in flight), "[i]t is clear that [§ 1498] was enacted for the purpose of enabling the Government to

${ }^{256}$ See Masnick, supra note 165.

257 See Elliot Harmon, How Patent Abuse Could Hurt the Fight Against the Pandemic, SLATE (Apr. 27, 2020), https://slate.com/technology/2020/04/patentabuse-government-research-coronavirus.html; Alex Moss \& Elliot Harmon, The Feds Can Stop Patent Trolls from Endangering COVID-19 Testing and Treatment, ELECTRONIC FRONTIER FOUND. (Mar. 25, 2020), https://www.eff.org/deeplinks/ 2020/03/feds-can-stop-patent-trolls-endangering-covid-19-testing-andtreatment.

${ }^{258}$ See supra text accompanying note 232.

${ }^{259}$ Advanced Software Design Corp. v. Fed. Reserve Bank of St. Louis, 583 F.3d 1371, 1378 (Fed. Cir. 2009).

${ }^{260}$ Iris Corp. v. Japan Airlines Corp., 769 F.3d 1359, 1362 (Fed. Cir. 2014). In Iris, the quasi-governmental function was detection of fraudulent passports.

${ }^{261}$ Supra text accompanying notes $47-103$. 
purchase goods for the performance of its functions without the threat of having the supplier enjoined . . .."262

Government patent use to protect, even encourage, socially beneficial but patent-infringing activity may have wider import and application than generally appreciated. We are not aware of other scholars who have drawn the connection, but it seems to us that such use of $\S 1498$ could even serve a fair use-like function within patent law, in emergency and normal periods alike. Prominent scholars have proposed that patent law should, through statutory reform or perhaps through judicial intervention, develop a fair use doctrine comparable to copyright law's. ${ }^{263}$ Strandburg, for example, has observed that "there are situations in which the social costs of exclusivity in a particular context simply outweigh the social benefits of the additional patent incentive provided by infringement liability in that context, such that use in that context should be permitted without conditions."264 Government patent use allows the U.S. government to do just that, making government authorization under $\S 1498$ a rough surrogate for a judicial determination that fair use applies. $^{265}$

In addition, though we are not aware of a historical example or proposal, it seems clear to us that government patent use under $\S 1498$ could be deployed as a shield in connection with a non-patent innovation incentive: innovation prizes set by the U.S. government. ${ }^{266}$ Prizes as an innovation incentive encourage many competitors to race all at once to solve a problem, but if one competitor obtains and enforces patents on a technology needed to reach or commercialize the prize goal, then they may be able to extract royalties or even enjoin the prizewinner, reducing the value of the innovation incentive. A straightforward way to avoid this problem would be for the government to guarantee $\S 1498$ as a shield: it could authorize the use of any patents needed to develop,

${ }^{262}$ Coakwell v. United States, 372 F.2d 508, 511 (1967).

263 See Maureen A. O'Rourke, Toward a Doctrine of Fair Use in Patent Law, 100 COLUM. L. REV. 1177 (2000); Strandburg, supra note 200.

${ }^{264}$ Strandburg, supra note 200, at 278.

265 Jacob Victor has argued, in the copyright context, that compulsory licensing and fair use provisions of the Copyright Act ultimately similarly serve the same ends of maximizing social utility. See Jacob Victor, Reconceptualizing Compulsory Copyright Licenses, 72 STAN. L. REV. 915 (2020); Jacob Victor, Utility-Expanding Fair Use, 105 MINN. L. REV. (forthcoming 2021).

266 Supra Part II.B. 
test, or commercialize the prizewinning innovation. This would enable those vying for the prize to use any and all existing technology freely in solving the prize problem, increasing the effectiveness of the prize.

Like government patent use, a patent buyout could also shield socially beneficial third-party activity, but a buyout will often be inferior to government patent use. When the government knows precisely which patents stand in the way of that activity - as when the company that makes COVID-19 testing equipment was sued for infringement - it could purchase or license them from the patent holders and then extend the necessary licenses to the third-party infringer. In this situation, the benefits of a buyout would be comparable to those of $\S 1498$. However, when the relevant patents have not been identified in advance of the infringing activity - as in the prize-setting scenario-buyouts will generally be more difficult than government patent use, as they will require the government to undertake a lengthy and expensive search to find those patents before it can begin the buyout negotiation. Separately, when a patent holder has already brought suit against an alleged third-party infringer - or is negotiating a buyout with the U.S. government to immunize that infringer - the hold-up or nuisance value of the suit may lead the patent holder to demand a price higher than the value of the patented technology, making a buyout more expensive for the government than use of $\S 1498 .^{267}$

\section{Ex Post Remedy Determination}

Under $\S 1498$, the appropriate compensation due to the patent owner is determined ex post, when the injured patent holder brings a claim for compensation in the Court of Federal Claims. In this regard, the remedy is determined not just ex post but "extra" ex post-that is, not merely after the invented technology is successfully reduced to practice and becomes worthy of a patent, ${ }^{268}$ but after, and often long after, the government and the public at large actually make use of the patented invention. Given the typical

${ }^{267}$ See, e.g., John R. Allison, Mark A. Lemley \& David L. Schwartz, How Often Do Non-Practicing Entities Win Patent Suits?, 32 BerKeley TeCH. L.J. 237, 242, $255 \&$ nn.22 \& 80 (2017) (describing "nuisance-value settlements" in patent infringement cases); Megan M. La Belle, Against Settlement of (Some) Patent Cases, 67 VAND. L. REV. 375, 403 (2014).

${ }^{268}$ It is in this sense that Hemel and Ouellette use the phrase "ex post." See Hemel \& Ouellette, supra note 167, at 544. 
pendency of a lawsuit under $\S 1498,{ }^{269}$ this could mean several years elapse between the government's first use of a patent and the determination of appropriate compensation. Sufficient time passes that when the Court of Federal Claims awards the "reasonable and entire compensation" owed under $\S 1498$, it often adds interest on the reasonable royalty, to make the patent holder whole for the time passed since government patent use began. ${ }^{270}$ This patience is a feature, not a bug, of government patent use.

In our view, patience in determining compensation has numerous benefits in a fast-moving national crisis like COVID-19. Sober patent valuation is hard amidst a pandemic or other national emergency. ${ }^{271}$ For example, estimates of the value of a vaccine or treatment may be wildly variable until its therapeutic propertiese.g., its side effects, its efficacy, and, in the case of a vaccine, its duration of effect - are fully established, years after first approval and the first purchases. (As the FDA has stated, "the true picture of a product's safety actually evolves over the months and even years that make up a product's lifetime in the marketplace." ${ }^{272}$ ) In that sense, $\S 1498$ may actually end up offering the patent holder a better deal, in the end, than a buyout: if the emergency takes a turn substantially for the worse or the invention turns out to be especially useful, the compensation paid under $\S 1498$ would be greater than a one-time ex ante payment.

A separate benefit of patience is that it avoids any potential problems with "royalty stacking": the situation where a single

269 See Michael J. Schaengold \& Robert S. Brams, Choice of Forum for Government Contract Claims: Court of Federal Claims vs. Board of Contract Appeals, 17 FED. CIR. B.J. 279, 321 (2008) (suggesting that across all cases in the Court of Federal Claims, "[b]arring extensive filing of pretrial motions, it will take approximately two years for a case to progress from the filing of the complaint to the issuance of a decision").

${ }^{270}$ See Decca Ltd. v. United States, 640 F.2d 1156, 1168 (Ct. Cl. 1980) ("The other component of 'reasonable and entire' compensation for a patent license taken by the Government is delay compensation. Delay compensation is recompense for the Government's delay in paying for the license."); 7 CHISUM, supra note 192, $\S 20.03$ ("[A] patent owner may recover prejudgment interest as delay compensation ....”')

${ }^{271}$ For a broader analysis of how delaying the calculation of damages in patent infringement cases can improve courts' analysis and accuracy, see Lichtman, supra note 200.

272 Step 5: FDA Post-Market Drug Safety Monitoring, U.S. FoOD \& DRUG ADMIN. (Jan. 4, 2018), https://www.fda.gov/patients/drug-development-process/step-5fda-post-market-drug-safety-monitoring. 
product infringes multiple patents held by multiple patent owners, increasing the risk of hold-up by one or more of those patent holders, as well as the risk of overcompensation of patent holders whose technology contributes only a small portion of the product's value. ${ }^{273}$ Given the flurry of inventive activity directed to COVID19 , it is very possible that we will see overlapping patent rights on important technologies like ventilator designs (as noted above) and research tools for vaccine development. (While less common in pharma, royalty stacking problems sometimes emerge there, too, ${ }^{274}$ especially with biologic drugs, whose manufacture may be more complex than that of small molecules drugs.) If there are multiple patent holders with patents infringed by products used by the government under $\S 1498$, they can all bring claims to the CFC, and (in a consolidated case) the judge could apportion the value of each patent holders' contribution to the product and allocate compensation accordingly. By contrast, in a buyout situation, the government risks overpaying if it negotiates a buyout with one patent holder without recognizing that other patent holders hold additional relevant patents. (The government could undertake a comprehensive search of others' patents and buy those out, too, but this would impose unnecessary search costs on the government and slow it down unnecessarily, as noted above.)

Of course, if a patent holder in fact thinks it would get a better deal from determination of the value of the patent after the government uses it, it could achieve the same result-or any of a flexible array of outcomes - through a patent buyout. For example, the patent holder for an effective COVID-19 treatment could offer rights to its drug for $\$ X$ upfront plus $\$ Y$ per use plus $\$ Z$ on the basis of patient outcomes (as determined through, say, an arbitration process). But such a negotiation would take time - and could thus cost additional lives - to produce an effective ex post evaluation system comparable to what already exists under $\S 1498$.

Indeed, these same problems - uncertainty and time wasted in attempting to predict the value of the government's use before it has

${ }^{273}$ See Mark A. Lemley \& Carl Shapiro, Patent Holdup and Royalty Stacking, 85 TEX. L. REV. 1991, 1993 (2007); Benjamin C. Li, The Global Convergence of FRAND Licensing Practices: Towards "Interoperable" Legal Standards, 31 BERKELEY TECH. L.J. 429, 432 (2016).

${ }^{274}$ See, e.g., Leila Abboud, Abbott's Bid to Squeeze Royalties May Carry Wider Impact, WALL ST. J., Nov. 22, 2004, https://www.wsj.com/articles/ SB110108567498880474. 
occurred-afflict not only patent buyouts but government-funded direct grants and prizes, too. Government grants are disbursed to innovators before their inventions are complete and are therefore an example of what Hemel and Ouellette term ex ante incentivesmonetary incentives whose incentive value is set before results are achieved. ${ }^{275}$ Prizes are "ex post" incentives in the Hemel and Ouellette sense - they are disbursed only after an invention proves successful. Yet prizes turn out to share a common Achilles heel with grants: they require the government to set the value of the incentive long prior to the government's use, and typically before inventions have been reduced to practice. For a prize to have any utility in incentivizing innovation, the government must set and announce the prize, and commit itself to a payout, before innovators have begun experimenting. It is true that the incentive size of a prize, like that a patent buyout, is flexible and can be conditioned on the value of the patented technology and the government's use thereof-e.g., \$X upon proof of a functional prototype plus \$Y per government use plus $\$ Z$ on the basis of patient outcomes. Such conditions can limit the government's risk of overpaying for an invention that proves only marginally useful. But these conditions only reduce risk; they cannot eliminate it. When setting the size of a prize, the government must always hazard some estimates about the costs of developing an invention and its social utility. In a fast-moving emergency, this is a serious drawback. The government needs time and resources to gather information to make those estimates - time and resources it may not have. Use of $\S 1498$ eliminates this uncertainty inherent in prizes, since the court-ordered reasonable and entire compensation always coincides with the precise extent of the government's use. ${ }^{276}$

The fact that compensation under $\S 1498$ coincides with the precise scope of the government's use produces another advantage of government patent use as compared to buying a patent outright: by choosing government patent use, the government will likely spend less of the public's money. Any time the government uses a patent under $\S 1498$, the patent holder retains substantial rights in the patent: a right to continue practicing the patent, a right to license it to third parties, a right to enforce it against third parties not

\footnotetext{
${ }^{275}$ Hemel \& Ouellette, supra note 167, at 556.

${ }^{276}$ Indeed, one might consider compensation under $\S 1498$ "to effectively set an ex post prize" with the advantage that the adjudicator may "examine evidence of market share" before setting it. Brennan et al., supra note 11, at 317.
} 
authorized by the government, and so on. And government patent use is typically time-limited. As soon as the government ceases using the patent, the patent holder's ability to exploit the patent is restored in full. As such, even expansive government patent use necessarily leaves a significant fraction of the total value of the patent in the hands of the patent holder, and the reasonable and entire compensation the government pays under $\S 1498$ should always be less than the price the government would pay in an outright buyout of the patent. ${ }^{277}$

To be sure, ex post determination of the appropriate compensation can have drawbacks, too, in some contexts. Small innovative companies may rely primarily or entirely on revenues from their patents to raise capital and sustain themselves, and they may not be able to wait years for compensation. In such circumstances, the U.S. government might voluntarily choose to pay compensation for government patent use sooner to keep the companies afloat, or it might decide to use another policy tool (such as a buyout) instead. The government should weigh potential impacts on the patent holder, its investors, and broader incentives in the sector before deciding to use $\S 1498$, and whether to make a large intervention or a small one. ${ }^{278}$

If HHS does elect to use $\S 1498$ to procure drugs, tests, ventilators, and other technologies necessary to navigate the COVID-19 crisis, it could take steps from the start to ensure a deep evidentiary record to support the determination of appropriate compensation when the day comes. For example, HHS could ask that the recipients of products procured through $\S 1498$ document who uses these products and how well these products work. HHS could also put known patent holders on notice as to its exercise of $\S 1498$ and encourage them to collect and keep data that will be useful if the CFC must later determine the appropriate level of compensation under $\S 1498$, such as data on the patent holder's R\&D costs and the patent holder's perception of the value of its invention. Asking patent holders to collect and retain such data is efficient - the patent holder is likely best positioned to generate useful evidence about the value of the invention - and patent holders

277 See Mitchell, supra note 27, at 553 ("The fair market value indicates what a willing buyer would pay for ownership, while a reasonable royalty is simply what a licensee would pay for ongoing use of the patent as a licensee.").

278 See supra Part III.A.2. 
have good incentives to collect reliable evidence that will hold up to court scrutiny, as we discuss in the next subpart.

\section{Determination of Compensation by an Impartial Adjudicator}

Finally, a fourth key feature of government patent use under $\S 1498$ is the adjudicator of the remedy: when the U.S. government uses patents, the appropriate compensation is decided not by the government or the patent holder but by impartial judges. As noted above, this makes $\S 1498$ a liability rule: the value of the patent is objectively determined (by a court) rather than subjectively determined by the patent holder and the government's negotiator.

Placing the question of patent valuation in the hands of an independent arbiter has numerous benefits. First, many of the entities likely to hold important patents on COVID-19 technologies are the same set of pharmaceutical, medical device, and biotechnology companies who wield some of the most powerful lobbies in the United States ${ }^{279}$ and who have been accused for decades of government and media capture, ${ }^{280}$ price-gouging, ${ }^{281}$ strategic gamesmanship of the patent and data exclusivity

${ }^{279}$ Karl Evers-Hillstrom, Big Pharma Continues to Top Lobbying Spending, OPENSECRETS (Oct. 25, 2019), https://www.opensecrets.org/news/2019/10/bigpharma-continues-to-top-lobbying-spending/; see also Wayne \& Petersen, supra note 237 (observing that, as of 2001, the pharmaceutical industry's lobby had "managed to stave off many actions that would harm them, like violating patents or forcing them to supply free drugs").

${ }^{280}$ See, e.g., Julie MARGETtA Morgan \& Devin DufFy, The Cost OF CAPTURE: How the Pharmaceutical Industry Has Corrupted Policymakers and HARMED PATIENTS, ROOSEVELT INSTITUTE ISSUE BRIEF 2019 (May 2019), https:// rooseveltinstitute.org/wp-content/uploads/2019/05/RI_Pharma_Cost-of-

Capture_brief_201905.pdf; Gringarten, supra note 104, at 74-76 (describing Bayer's "crisis management" lobbying efforts to shape media coverage and the U.S. government's response to the anthrax crisis); Alexander Zaitchik, How Big Pharma Was Captured by the One Percent, New RePUBLIC (June 28, 2018), https://newrepublic.com/article/149438/big-pharma-captured-one-percent.

${ }^{281}$ See, e.g., KeVIN T. Richards et Al., Cong. Research SerV., Report No. R46221, Drug Pricing AND Pharmaceutical Patenting Practices 2 (2020) ("critics argue that these patenting practices are used to keep drug prices high, without any benefit for consumers or innovation"); MÉDECINS SANS FRONTIÈRES, Lives on the Edge: Time To Align Medical Research and Development with People's Health NeEds 17 (2016) (collecting examples of alleged pharmaceutical industry price-gouging and profiteering). 
systems, ${ }^{282}$ and antitrust violations. ${ }^{283}$ (And others may be nonpracticing patent assertion entities like Labrador Diagnostics, noted above. ${ }^{284}$ ) As noted earlier, there is a real risk of gamesmanship and hold-up by this set of patent holders in the event of a rushed buyout precipitated by an ongoing public health crisis. ${ }^{285}$ Hold-up in patent buyouts can lead not only to harmful delay but also to the government overpaying.

In a patent buyout, patent holders are not the only worry. As noted above, ${ }^{286}$ the U.S. government does not appear to have negotiated a patent buyout in over 60 years. As such, the government's own negotiators are likely inexperienced and ill prepared to enter a high-stakes buyout negotiation, whether in a time of emergency or not. Indeed, the government's IP negotiators may not even have deep expertise in other types of IP valuation, such as licensing the government's own patent portfolio. For example, the Department of Defense's intellectual property negotiators were, as of 2018, sufficiently inexpert that Congress demanded formation of a "cadre of IP experts" to help. ${ }^{287}$

By contrast, the judges of Court of Federal Claims have deeper and recent experience in valuing patents in $\S 1498$ cases, as

${ }^{282}$ See generally Robin Feldman, May Your Drug Price Be Evergreen, 5 J.L. \& BIOSCIENCE 590 (2018); RICHARDS ET AL., supra note 281. For specific examples of alleged gamesmanship and misuse of patent and data exclusivity, see Allergan, Inc. v. Teva Pharm. USA, Inc., No. 2:15-cv-1455, 2017 WL 4619790, at *2 (Oct. $16,2017)$ (court expressing "serious concerns about the legitimacy of" Allergan's efforts to immunize its patents from challenge by transferring ownership to a Native American tribe); Michael Daniel et al., The Orphan Drug Act: Restoring the Mission to Rare Diseases, 39 AM. J. ClinICAL ONCOLOGY 210 (2016).

${ }^{283}$ See, e.g., Michael A. Carrier, Higher Drug Prices from Anticompetitive Conduct: Three Case Studies, 39 J. Legal Med. 151 (2019) (documenting examples of anticompetitive conduct by pharmaceutical companies); C. Scott Hemphill, Paying For Delay: Pharmaceutical Patent Settlement as a Regulatory Design Problem, 81 N.Y.U. L. REV. 1553, 1568 (2006) (describing widespread anticompetitive "pay-for-delay" tactics by pharmaceutical companies).

${ }^{284}$ Supra notes 256-260.

${ }^{285}$ Supra notes 236-238 and accompanying text.

${ }^{286}$ See supra note 179.

${ }^{287}$ See National Defense Authorization Act for Fiscal Year $2018 \S 802(\mathrm{~b}), 10$ U.S.C. § 2322; see also Adam Bartolanzo \& Keith Szeliga, Contractors Beware: The 2018 NDAA Ushers In New Changes Affecting IP Rights, Gov'T CONT. \& INVESTIGATIONS BLOG (Jan. 30, 2018), https://www.governmentcontractslaw blog.com/2018/01/articles/department-of-defense/ndaa-ip-rights. 
numerous cases are brought every year. ${ }^{288}$ This experience means there is a body of law on the reasonable and entire compensation under $\S 1498$ that helps to anchor the calculation and provide some consistency and predictability - something missing in a patent buyout. While we are not aware of a recent, in-depth empirical review of the consistency and predictability of damages awards in $\S 1498$ cases decided by the Court of Federal Claims, some anecdotal evidence suggests that they are at least on par with those in the federal district courts. ${ }^{289}$ While calculation of damages in patent cases is inherently complex and somewhat unpredictablereasonable royalties very much included-the expertise and experience of the judges of the Court of Federal Claims should allay concerns somewhat.

Other benefits flow from $\S 1498$ 's use of the Court of Federal Claims as impartial adjudicator to determine compensation. ${ }^{290}$

${ }^{288}$ A Westlaw search for Court of Federal Claims cases returned 134 decisions decided between January 1, 2010 and December 31, 2019 that reference "28 U.S.C. § 1498" and "patent." In the 1990s, Lavenue calculated that "[s]ince the enactment of 28 U.S.C. $\S 1498$, the Court of Federal Claims and its predecessor courts have decided an average of five and one-half cases a year." Lavenue, supra note 18 , at 496 .

${ }^{289}$ In an empirical study published 2001, Chu concluded that judgments of the Court of Federal Claims in patent cases are affirmed by the Federal Circuit at a higher rate (and reversed at a lower rate) than is true for any district court in the nation. See Christian A. Chu, Empirical Analysis of the Federal Circuit's Claim Construction Trends, 16 BERKELEY TECH. L.J. 1075, 1124-25 (2001). In Return Mail, Inc. v. United States Postal Service, the Supreme Court suggested that remedies in $\S 1498$ cases are at least as predictable as remedies in 35 U.S.C. $\S 271$ cases brought in district court, though the Court's analysis focused on the simple fact that injunctions are not available in $\S 1498$ cases but are in 35 U.S.C. $\S 271$ cases. See 139 S. Ct. 1853, 1867 (2019) ("[A]lthough federal agencies remain subject to damages for impermissible uses, they do not face the threat of preliminary injunctive relief that could suddenly halt their use of a patented invention, and they enjoy a degree of certainty about the extent of their potential liability that ordinary accused infringers do not.").

290 One significant cost flows from $\S 1498$ 's use of a court to determine compensation: the costs of litigation. We are not aware of specific estimates of the costs of litigation under $\S 1498$, but district court patent infringement suits and Section 337 investigations at the International Trade Commission cost a median of \$700,000 to \$4 million in 2019. See Scott McBride, Strategies For Controlling Costs in Patent Litigation, LAw360 (Sept. 12, 2019), https://www.law360.com/ articles/1198463/strategies-for-controlling-costs-in-patent-litigation. These costs are real, but we think them acceptable, for four reasons. First, small patent holders' 
Federal judges of the CFC appointed to 15 -year terms ${ }^{291}$ are also insulated from the pernicious influence of industry lobbying in a way that the U.S. government's negotiators may not be. Discovery in litigation will disgorge otherwise secret information relevant to the calculation of compensation - on the patent holder's R\&D costs, on others' (including the government's) contributions to that R\&D, on the value of the patented invention (e.g., a drug's safety and efficacy), and so on. ${ }^{292}$ And the critical issues of patent validity, enforceability, and infringement can be properly ventilated and decided. (Like any defendant in standard infringement litigation, the government owes no compensation whatsoever if the asserted patent turns out to be invalid, unenforceable, or not infringed.) Patent holders may benefit from this independent adjudicator, too, insofar as the government cannot use its vast media and regulatory powers, or its sometime monopsony purchaser status, to strong-arm an unduly cheap deal.

\section{B. A Case Study for the Use of $\$ 1498:$ Remdesivir in the COVID-19 Pandemic}

To exemplify how policymakers can weigh these four advantages of $\S 1498$ to assess its applicability, this Part considers how these advantages apply to the COVID-19 pandemic and the experimental drug remdesivir, one of the few treatments for

costs are typically paid by the government in a successful $\S 1498$ action. See $\S 1498$ (a) ("Reasonable and entire compensation shall include the owner's reasonable costs, including reasonable fees for expert witnesses and attorneys, in pursuing the action if the owner is an independent inventor, a nonprofit organization, or an entity that had no more than 500 employees at any time during the 5-year period preceding the use or manufacture of the patented invention by or for the United States."). Second, from the public's perspective, even paying both a successful patent holder's costs and the government's will be cost-effective in situations where the value of the patented technology used - potentially worth hundreds of millions or billions of dollars - will dwarf those costs. Third, the costs of litigation are, to some extent, simply the unavoidable costs of gathering (through discovery and judicial fact-finding) useful information on the value of the patent; collecting the same information prior to a patent buyout, for example, would also incur costs. Fourth, like any litigants, the patentee plaintiff and the U.S. government can settle at point prior to or during litigation and thereby avert further litigation costs. See Lemley, supra note 158, at 473.

${ }^{291}$ See 28 U.S.C. $\$ 172$.

${ }^{292}$ See Brennan et al., supra note 11, at 316 (discussing the value of discovery and expert testimony in actions brought under $\S 1498$ to determine "R\&D outlays and the risk of failure at each stage of investment" in the patented invention). 
COVID-19 currently available. ${ }^{293}$ Remdesivir is also economically significant - the potential U.S. market for the drug has been estimated in the billions of dollars per year for years to come. ${ }^{294} \mathrm{We}$ trace below how the U.S. government could use $\S 1498$ to expand supplies of the drug while simultaneously spending less (and produce savings for private payers, too).

We select remdesivir largely because it is a "ripe" example: a fully developed anti-COVID-19 technology about which we now have meaningful information on manufacturing costs, supply limitations, retail pricing, patent protection, and so on. ${ }^{295}$ But the logic of government patent use to expand supply and lower prices could apply equally to other currently experimental and patented technologies useful against COVID-19, such as monoclonal antibodies, ${ }^{296}$ new diagnostics, and, perhaps most important, a vaccine. The United States and other countries have invested unprecedented sums to accelerate vaccine development, ${ }^{297}$ but there currently are profound concerns that the public may not get access

${ }^{293}$ See, e.g., Matthew Herper, Covid-19 Study Details Benefits of Treatment with Remdesivir, and Also Its Limitations, STAT (May 22, 2020), https://www. statnews.com/2020/05/22/covid-19-study-details-benefits-of-treatment-withremdesivir-and-also-its-limitations.

${ }^{294}$ Cristin Flanagan, Gilead Upgraded With Covid Sales Seen Reaching \$7.7 Billion, BlOOMBERG (June 3, 2020), https://www.bloomberg.com/news/articles/ 2020-06-03/gilead-loses-a-skeptic-with-remdesivir-sales-seen-at-7-billion.

${ }^{295}$ One of us (C.J.M.) published earlier, briefer analyses of potential exercise of government patent use to expand access to and lower prices on remdesivir. See Christopher Morten, Christian Urrutia \& James Krellenstein, A Powerful Law Gives HHS the Right to Take Control of Remdesivir Manufacturing and Distribution, STAT (July 2, 2020), https://www.statnews.com/2020/07/02/ powerful-law-gives-hhs-right-to-control-remdesivir-manufacturing-distribution; James Krellenstein \& Christopher J. Morten, U.S. Government's Apparent CoOwnership of Patents Protecting Remdesivir, PREP4ALL (May 20, 2020), https:// www.prep4all.org/news/remdesivir.

${ }^{296}$ Janet Woodcock, the Director of the Center for Drug Evaluation and Research at the FDA, has publicly expressed concern about inadequate supplies of antiCOVID-19 monoclonal antibodies and the possible need to draw on global monoclonal antibody manufacturing capacity. See Carolyn Y. Johnson, Operation Warp Speed Is Pushing for Covid-19 Therapeutics by Early Fall, WASH. POST (July 13, 2020), https://www.washingtonpost.com/health/2020/07/13/operationwarp-speed-is-pushing-covid-19-therapeutics-by-early-fall.

${ }^{297}$ See Mapping of Global Public Funding for Covid-19, UnIVs. ALLIED FOR ESSENTIAL MEDS. (2020), https://www.publicmeds4covid.org. 
to a vaccine despite this public funding, ${ }^{298}$ should global demand overwhelm the manufacturing and distribution capabilities of patent holders. ${ }^{299}$ Our analysis of $\S 1498$ and remdesivir would likely apply with equal force to a hypothetical vaccine patent, but vaccines exhibit additional considerations that we discuss briefly in this Part. ${ }^{300}$

\section{Remdesivir: An Experimental Drug That Promises Modest but Important Benefits}

What is remdesivir? It is a small molecule experimental antiviral drug manufactured by Gilead Sciences, Inc. ("Gilead"), under the brand name Veklury. ${ }^{301}$ Gilead holds patents on remdesivir and is the sole supplier in the United States. Remdesivir was originally developed through a collaboration by Gilead, the Centers for Disease Control and Prevention (CDC), and U.S. Army Medical Research Institute of Infectious Diseases (USAMRIID) and was tested against numerous viruses, including Ebola, but proved ineffective against them. ${ }^{302}$

${ }^{298}$ See, e.g., Will Feuer \& Noah Higgins-Dunn, WHO Warns Against Coronavirus "Vaccine Nationalism and Risk of Price Gouging", CNBC (Aug. 13, 2020), https://www.cnbc.com/2020/08/13/who-warns-against-coronavirus-vaccinenationalism-and-risk-of-price-gouging.html; Elisabeth Rosenthal, How a Covid19 Vaccine Could Cost Americans Dearly, N.Y. TIMES (July 6, 2020), https:// www.nytimes.com/2020/07/06/opinion/coronavirus-vaccine-cost.html.

${ }^{299}$ See, e.g., Damien Garde \& Helen Branswell, 6 Burning Questions Congress Could Push Covid-19 Vaccine Makers to Answer Today, STAT (July 20, 2020), https://www.statnews.com/2020/07/20/covid19-vaccines-merck-modernacongress; Christopher Rowland et al., Even Finding a Covid-19 Vaccine Won't Be Enough to End the Pandemic, WASH. Post (May 11, 2020), https://www. washingtonpost.com/business/2020/05/11/coronavirus-vaccine-global-supply;

Julie Steenhuysen \& Kate Kelland, Vaccine Makers Face Biggest Medical Manufacturing Challenge in History, ReUTERS (June 25, 2020), https://www. reuters.com/article/us-health-coronavirus-vaccines-manufactu-idUSKBN23W1 ND.

${ }^{300}$ See infra text accompanying notes 359-366. See generally Ana Santos Rutschman, The COVID-19 Vaccine Race: Intellectual Property, Collaboration(s), Nationalism and Misinformation, 64 WASH. U. J.L. \& POL'Y (forthcoming 2021), https://papers.ssrn.com/sol3/papers.cfm?abstract_id= 3656929.

301 Gilead Scis., Fact Sheet for Health Care Providers: Emergency Use Authorization (EUA) of Veklury (remdesivir) (July 2020), https://www.gilead. com/-/media/files/pdfs/remdesivir/eua-fact-sheet-for-hcps.pdf.

302 See Dustin Siegel et al., Discovery and Synthesis of a Phosphoramidate Prodrug of a Pyrrolo[2,1-f][triazin-4-amino] Adenine C-Nucleoside (GS-5734) 
Remdesivir's safety and therapeutic benefits in COVID-19 patients are still being investigated, ${ }^{303}$ but as of writing, those benefits appear both modest and significant. One clinical trial sponsored by the National Institute of Allergy and Infectious Diseases (NIAID) has shown that remdesivir helps hospitalized patients with severe COVID-19 recover and leave the hospital more quickly than a placebo - a median of 4 days more quickly. ${ }^{304}$ Another trial showed some statistically significant benefit in recovery time in patients whose COVID-19 symptoms were moderate (rather than severe) and who received 5 days of treatment with the drug. ${ }^{305} \mathrm{~A}$ third trial that terminated early due to underenrollment showed no statistically significant improvement in COVID-19 patients treated with remdesivir compared to placebo. ${ }^{306}$ Remdesivir has not been shown in any rigorous clinical trial to reduce mortality in COVID-19 patients - that is, to save lives. ${ }^{307}$

Although the clinical trial data supporting remdesivir's use in COVID-19 patients is limited, doctors have few good alternatives. ${ }^{308}$ Based on the NIH trial, FDA granted an emergency

for the Treatment of Ebola and Emerging Viruses, 60 J. MEDICINAL CHEMISTRY 1648 (2017); Travis K. Warren et al., Therapeutic Efficacy of the Small Molecule GS-5734 Against Ebola Virus in Rhesus Monkeys, 530 NATURE 381 (2016). For remdesivir's failure as a treatment for Ebola, see Helen Branswell, Two Ebola Treatments Yield "Substantial Decrease" in Mortality, Landmark Trial Shows, STAT (Nov. 27, 2019), https://www.statnews.com/2019/11/27/two-ebolatreatments-mortality-decrease/; Gina Kolata, How Remdesivir, New Hope for Covid-19 Patients, Was Resurrected, N.Y. TIMES (May 1, 2020), https:/www. nytimes.com/2020/05/01/health/coronavirus-remdesivir.html.

303 See Ameet Sarpatwari et al., Missed Opportunities on Emergency Remdesivir Use, 324 J. AM. MED. Ass'N 331 (2020).

304 See John H. Beigel et al., Remdesivir for the Treatment of Covid-19Preliminary Report, 383 NEW ENG. J. MED. 1813 (2020).

305 See Christoph D. Spinner et al., Effect of Remdesivir vs Standard Care on Clinical Status at 11 Days in Patients with Moderate COVID-19: A Randomized Clinical Trial, 324 J. AM. MED. Ass'N 1048 (2020).

306 See Yeming Wang et al., Remdesivir in Adults with Severe COVID-19: A Randomised, Double-Blind, Placebo-Controlled, Multicentre Trial, 395 LANCET 1569 (2020), https://doi.org/10.1016/s0140-6736(20)31022-9.

${ }^{307}$ Matthew Herper, Major Study Finds Common Steroid Reduces Deaths Among Patients with Severe Covid-19, STAT (June 16, 2020), https://www.statnews.com/ 2020/06/16/major-study-finds-common-steroid-reduces-deaths-among-patientswith-severe-covid-19.

308 See Denise Grady, Malaria Drug Promoted by Trump Did Not Prevent Covid Infections, Study Finds, N.Y. TIMES (June 3, 2020), https://www.nytimes.com/ 
use authorization (EUA) to the drug on May 1, 2020. ${ }^{309}$ Remdesivir has been described by Dr. Anthony Fauci, an infectious disease expert and one of the leaders of the White House Coronavirus Task Force, as the current "standard of care" for COVID-19, ${ }^{310}$ and the drug has already been used in thousands of patients. ${ }^{311}$

Should further clinical trial data prove that remdesivir is indeed safe and effective at reducing COVID-19 mortality, it will be an indispensable tool in the COVID-19 response in the United States and around the world. Even if the drug saves no lives but merely accelerates recovery in patients with severe disease, it will nonetheless be valuable, considering the enormous social benefits of keeping people out of the hospital. A single day in an American intensive care unit (ICU) costs thousands of dollars, ${ }^{312}$ so accelerating recovery by even a day has significant economic

2020/06/03/health/hydroxychloroquine-coronavirus-trump.html. In June and July 2020, a group at the University of Oxford reported clinical trial results suggesting that the widely available steroid dexamethasone successfully reduced mortality in patients with moderate or advanced COVID-19 disease who were receiving mechanical ventilation or oxygen. See Nancy Lapid, Steroid's COVID-19 Benefits Confirmed; Spotlight on Immune Cells, ReUTERS (July 18, 2020), https://www. reuters.com/article/us-health-coronavirus-science-idUSKCN24I2SY.

${ }^{309}$ See Press Release, U.S. Food \& Drug Admin., Coronavirus (COVID-19) Update: FDA Issues Emergency Use Authorization for Potential COVID-19 Treatment (May 1, 2020), https://www.fda.gov/news-events/press-announce ments/coronavirus-covid-19-update-fda-issues-emergency-use-authorizationpotential-covid-19-treatment. In August 2020, the FDA expanded the EUA to cover hospitalized COVID-19 patients with more moderate disease. See Press Release, U.S. Food \& Drug Admin., COVID-19 Update: FDA Broadens Emergency Use Authorization for Veklury (Remdesivir) to Include All Hospitalized Patients for Treatment of COVID-19 (Aug. 28, 2020), https://www. fda.gov/news-events/press-announcements/covid-19-update-fda-broadensemergency-use-authorization-veklury-remdesivir-include-all-hospitalized.

${ }^{310}$ Sue Hughes, Remdesivir Now "Standard of Care" for COVID-19, Fauci Says, HoSPITALIST (Apr. 30, 2020), https://www.the-hospitalist.org/hospitalist/article/ 221518/coronavirus-updates/remdesivir-now-standard-care-covid-19-fauci-says.

${ }^{311}$ See Laurie McGinley \& Christopher Rowland, FDA Authorizes Use of Gilead Sciences' Remdesivir for Patients Severely Ill with Covid-19, WASH. POST (May 1, 2020), https://www.washingtonpost.com/health/2020/05/01/fda-authorizesuse-gilead-sciences-remdesivir-severely-ill-patients-with-covid-19.

${ }^{312}$ See Joseph S. Dasta et al., Daily Cost of an Intensive Care Unit Day: The Contribution of Mechanical Ventilation, 33(6) CRITICAL CARE MED. 1266 (2005), https://journals.lww.com/ccmjournal/Abstract/2005/06000/Daily_cost_of_an_ intensive_care_unit_day_The.13.aspx. 
benefits on that basis alone ${ }^{313}$ —not to mention the benefits of allowing people to return to their jobs, homes, and loved ones. Accelerating recovery also frees ICU beds, equipment, and personnel to treat more patients. ICU shortages have plagued many countries' early COVID-19 responses, exacerbating mortality, ${ }^{314}$ and experts suggested in spring and summer 2020 that the United States risks a new wave of ICU bed shortages in late 2020. ${ }^{315}$

\section{Two Problems: Shortages and Overpricing}

The United States's COVID-19 response faces two problems vis-à-vis remdesivir: the problem of shortage and the problem of overpricing.

The United States faced deep shortages of remdesivir through the spring and summer of 2020, causing physicians to ration the drug and patients to go without - shortages apparently caused at least in part by Gilead's inability to manufacture enough. ${ }^{316}$ Gilead has,

${ }^{313}$ Gilead's CEO, Daniel O'Day, justified the price Gilead intends to charge for remdesivir on this basis. See Press Release, An Open Letter from Daniel O'Day, Chairman \& CEO, Gilead Sciences (June 29, 2020), https://www.gilead.com/ news-and-press/press-room/press-releases/2020/6/an-open-letter-from-danieloday-chairman--ceo-gilead-sciences ("Taking the example of the United States, earlier hospital discharge would result in hospital savings of approximately $\$ 12,000$ per patient. Even just considering these immediate savings to the healthcare system alone, we can see the potential value that remdesivir provides."). There is some irony in a pharmaceutical company-a member of one oft-criticized sector of America's oft-criticized health care system - using high prices of hospital care - another oft-criticized sector of the same - to justify its own high prices.

${ }^{314}$ See Shadman Aziz et al., Managing ICU Surge During the COVID-19 Crisis: Rapid Guidelines, 46 InTENSIVE CARE MED. 1303 (June 8, 2020); Alberto Zangrillo \& Luciano Gattinoni, Learning from Mistakes During the Pandemic: The Lombardy Lesson, InTENSIVE CARE MED. (June 5, 2020).

315 See Will Feuer, CDC Says U.S. Has "Way Too Much Virus" to Control Pandemic as Cases Surge Across Country, CNBC (June 29, 2020), https://www. cnbc.com/2020/06/29/cdc-says-us-has-way-too-much-virus-to-control-

pandemic-as-cases-surge-across-country.html; Nolan D. McCaskill, Rising ICU Bed Use "a Big Red Flag”, POLITICO (May 28, 2020), https://www.politico.com/ news/2020/05/28/rising-icu-bed-use-red-flag-287552.

316 See Elizabeth Cohen, Covid-19 Drug Rationed in the US Is Plentiful in Developing Countries, CNN (Sept. 9, 2020), https://www.cnn.com/2020/09/09/ health/covid-remdesivir-us-vs-other-countries/index.html; Cristin Flanagan, Gilead's Virus Drug Seen in Short Supply for Americans, BLoomberg (May 11, 2020), https://www.bloomberg.com/news/articles/2020-05-11/gilead-s-covid-19drug-seen-in-short-supply-for-americans; Berkeley Lovelace Jr., Gilead Says It 
rather gradually, voluntarily licensed its patents to competitor drug manufacturers in the United States and overseas, ${ }^{317}$ which expanded its supplies, but not quickly enough. ${ }^{318}$

As the federal department ultimately responsible for navigating the country through the COVID-19 crisis, HHS has taken on itself the job of distributing of remdesivir to the hospitals in greatest need throughout the United States. ${ }^{319}$ But despite purported "coordination," HHS proved consistently unable throughout the spring and summer of 2020 to allocate the nation's (short) supplies efficiently or effectively. ${ }^{320}$ In an effort to address ongoing shortages, in June of 2020, HHS announced that it had contracted with Gilead to dedicate over $90 \%$ of Gilead's supply of remdesivir from July through September 2020 to the United States aloneabout 500,000 treatment courses. ${ }^{321}$ The deal was striking in its

Will Be Able to Make Enough Remdesivir to Meet Global Coronavirus Demand in October, CNBC (Aug. 6, 2020), https://www.cnbc.com/2020/08/06/gileadsays-it-will-be-able-to-make-enough-remdesivir-to-meet-global-coronavirus-

demand-in-october.html; Sydney Lupkin, How Feds Decide on Remdesivir Shipments to States Remains Mysterious, NPR (Aug. 19, 2020), https://www.npr. org/sections/health-shots/2020/08/19/903946857/how-feds-decide-on-

remdesivir-shipments-to-states-remains-mysterious.

${ }^{317}$ See Valerie Bauman, Gilead Gives Royalty-Free Remdesivir Licenses to Five Drugmakers, BlOOMBERG L. (May 12, 2020), https://news.bloomberglaw.com/ pharma-and-life-sciences/gilead-gives-royalty-free-remdesivir-licenses-to-fivedrugmakers; Peter Maybarduk, Remdesivir Should Be in the Public Domain; Gilead's Licensing Deal Picks Winners and Losers, PUB. Citizen (May 12, 2020), https://www.citizen.org/news/remdesivir-should-be-in-the-public-domaingileads-licensing-deal-picks-winners-and-losers/.

${ }^{318}$ After shortages were reported in the summer of 2020, Reuters reported in midSeptember 2020 that U.S. hospitals were turning away new shipments of remdesivir, suggesting that they had ample supplies and that shortages and rationing had ended. See Deena Beasley, Exclusive: U.S. Hospitals Turn Down Remdesivir, Limit Use to Sickest COVID-19 Patients, ReUTERS (Sept. 11, 2020), https://www.reuters.com/article/us-health-coronavirus-remdesivir-exclusiidUKKBN2622UM.

${ }^{319}$ Press Release, U.S. Dep't of Health \& Human Servs., HHS Announces Shipments of Donated Remdesivir for Hospitalized Patients with COVID-19 (May 9, 2020), https://www.hhs.gov/about/news/2020/05/09/hhs-ships-firstdoses-of-donated-remdesivir-for-hospitalized-patients-with-covid-19.html.

${ }^{320}$ See Kapczynski, Biddinger \& Walensky, supra note 12 (describing HHS's distribution as "uneven and opaque," and leading to shortages); see also Lupkin, supra note 316.

${ }^{321}$ Press Release, U.S. Dep't of Health \& Human Servs., Trump Administration Secures New Supplies of Remdesivir for the United States (June 29, 2020) 
nationalism and disregard of COVID-19 patients outside the United States-billions of people sick and at risk in countries outside Gilead's network of authorized generic suppliers ${ }^{322}$ may have no access to remdesivir. ${ }^{323}$ (And even those 500,000 doses proved insufficient to meet demand within the United States. ${ }^{324}$ ) In August 2020, Gilead announced that it expects, finally, to be able to manufacture enough remdesivir to meet global demand by early October, ${ }^{325}$ but despite projecting manufacture of two million doses this year, Gilead acknowledged to investors that "there is no assurance that we will be able to meet global supply needs for remdesivir." 326 Some experts, including former FDA Commissioner Gottlieb, have predicted new peaks of infections and hospitalizations in the fall of 2020 and winter of $2021 ;^{327}$ if their fears come to pass, then shortages of remdesivir may continue.

Besides shortages, the other problem is price. On June 29, 2020, Gilead announced what it plans to charge for remdesivir once donated doses run out in July 2020: $\$ 3,120$ for a typical course of treatment for patients with private insurance as well as those covered by Medicare and Medicaid, and \$2,340 for a smaller number of patients covered by certain other U.S. government insurance programs. ${ }^{328}$ The $\$ 3,120$ price tag is over ten times what an expert independent organization (the Institute for Clinical and Economic Review (ICER)) deems to be remdesivir's cost-effective value

[hereinafter HHS Press Release], https:/www.hhs.gov/about/news/2020/06/29/ trump-administration-secures-new-supplies-remdesivir-united-states.html.

322 See Ed Silverman, Gilead Signs Deals for Generic Companies to Make and Sell Remdesivir, STAT (May 12, 2020), https://www.statnews.com/pharmalot/ 2020/05/12/gilead-generics-remdesivir-covid19-coronavirus-licenses.

${ }^{323}$ Sarah Boseley, US Secures World Stock of Key Covid-19 Drug Remdesivir, GUARDIAN (June 30, 2020), https://www.theguardian.com/us-news/2020/jun/30/ us-buys-up-world-stock-of-key-covid-19-drug.

${ }^{324}$ See Cohen, supra note 316; Lovelace, supra note 316; Lupkin, supra note 316.

325 See Lovelace, supra note 316.

${ }^{326}$ Gilead Scis., Inc., Quarterly Report (Form 10-Q), at 30, 44 (Aug. 6, 2020), http://investors.gilead.com/static-files/5648e7dd-c981-4d5b-8c8f-

22342 d60a946.

327 See Joseph Guzman, America Could Have a Third Act of Coronavirus and It Will Likely Be “More Pervasive," Says Top Health Expert, HiLl (Aug. 21, 2020), https://thehill.com/changing-america/well-being/longevity/513125-americacould-have-a-third-act-of-coronavirus-and-it; see also Feuer, supra note 315. 328 See Matthew Herper, Gilead Announces Long-Awaited Price for Covid-19 Drug Remdesivir, STAT (June 29, 2020), https://www.statnews.com/2020/06/29/ gilead-announces-remdesivir-price-covid-19. 
$(\$ 310)^{329}$ and perhaps over three hundred times its manufacturing cost (which has been estimated at less than $\$ 10^{330}$ ). The $\$ 3,120$ price tag that most Americans will pay is the highest in the world (despite U.S. taxpayers' contributions to the drug); other wealthy countries will pay $\$ 2,340 .{ }^{331}$ Experts corroborate the view that the $\$ 3,120$ Gilead will charge most American patients is unfairly high, given the drug's moderate therapeutic value, its low manufacturing costs, and the American public's substantial contributions-at least $\$ 70,500,000$ - to its discovery and development. ${ }^{332}$ Gilead's prices for remdesivir will likely generate enormous revenue for the company ${ }^{333}$ but strain the budgets of federal and state public health

${ }^{329}$ See Melanie D. Whittington \& Jonathan D. Campbell, Alternative Pricing Models for Remdesivir and Other Potential Treatments for COVID-19, 2020 INST. FOR CLINICAL AND ECON. REV. 1, 6 (June 24, 2020), https://icer-review.org/wpcontent/uploads/2020/06/ICER-COVID_Revised_Report_20200624.pdf (concluding that $\$ 310$ is the appropriate cost-effectiveness price for remdesivir, given that it speeds recovery but has not been proven to reduce mortality).

${ }^{330}$ Andrew Hill et al., Minimum Costs to Manufacture New Treatments for COVID-19, 6 J. VIRUS ERADICATION 61 (Apr. 2020).

${ }^{331}$ See Michael Erman et al., Gilead Prices COVID-19 Drug Remdesivir at \$2,340 per Patient in Developed Nations, REUTERS (June 29, 2020), https://www.reuters. com/article/us-health-coronavirus-gilead-sciences-idUSKBN2401C8.

${ }^{332}$ See, e.g., Damian Garde \& Ed Silverman, Less than a Movie Ticket or "Impossible to Overpay"? Experts Name Their Price for Remdesivir, STAT (May 15, 2020), https://www.statnews.com/2020/05/15/gilead-remdesivir-pricingcoronavirus (quoting expert Peter Bach, director of Memorial Sloan Kettering's Center for Health Policy and Outcomes, as suggesting a price of about $\$ 1,000$ per patient as fair); Angus Liu, New Fair Price for Gilead's Remdesivir? Below $\$ 2,800$ if Dexamethasone Lives up to Its COVID-19 Promise, FIERCE PHARMA (June 24, 2020), https://www.fiercepharma.com/pharma/new-fair-price-forgilead-s-remdesivir-below-2-800-if-dexamethasone-lives-up-to-its-covid-19;

Jing Luo et al., Treatments Don't Work If We Can't Afford Them: The Global Need for Open and Equitable Access to Remdesivir, BMJ OPINION (June 3, 2020), https://blogs.bmj.com/bmj/2020/06/03/treatments-dont-work-if-we-cant-affordthem-the-global-need-for-open-and-equitable-access-to-remdesivir ("In higherincome countries, until more robust mortality data becomes available, existing evidence suggests that a price between 'at cost' $(\$ 10)$ and the lower of ICER's cost-effective estimates (\$390) is appropriate.”). Public Citizen has documented that the United States and other governments have contributed at least $\$ 70,500,000$ to the development of remdesivir. See The Real Story of Remdesivir, PUB. CitizEN (May 7, 2020), https://www.citizen.org/article/the-real-story-ofremdesivir/?eType=EmailBlastContent\&eId=9bdafb07-71bb-41dc-8726f80183f3f648.

${ }^{333}$ See Ed Silverman, Gilead's Pricing for Remdesivir Raises Questions About the 
agencies, insurers, and individual patients. ${ }^{334}$ HHS's plan to distribute 500,000 doses of remdesivir between July and September 2020 committed parts of the U.S. government and all private payers to paying full price. ${ }^{335}$

\section{Patents Are the Sole Significant Barrier to Access}

Government patent use can be effective in solving shortages and overpricing, but only if there are no other insurmountable barriers to competition. We consider three candidates for non-patent barriers to remdesivir manufacturing and distribution and find that none of them will likely be impassable.

First, although $\S 1498$ is limited to government patent use rather than generalized compulsory licensing, $\S 1498$ would still suffice to expand public access to remdesivir because the government could distribute the drug broadly. HHS's distribution of remdesivir (or any therapeutic or vaccine used against COVID-19) would satisfy the statute's requirement that authorization under $\S 1498$ be limited to products "used or manufactured by or for the United States." 336 Accelerating the recovery of people sick with COVID-19 and safeguarding hospital bed capacity clearly provides "significant benefits to the United States" and therefore meets the standard set out in Advanced Software. ${ }^{337}$ As of writing, HHS is already coordinating distribution of remdesivir throughout the United States and has been since the earliest days of the COVID-19 pandemic. ${ }^{338}$ HHS could, if it desired, purchase and distribute remdesivir through

Drug's Long-Term Prospects, STAT (June 29, 2020), https://www.statnews.com/ pharmalot/2020/06/29/gilead-remdesivir-covid19-coronavirus-drug-prices

(quoting a Wall Street prediction that Gilead could earn \$2.3B from remdesivir in 2020 alone).

${ }^{334}$ Garde \& Silverman, supra note 332.

${ }^{335}$ Libby Watson, Big Pharma's Got a Brand New Coronavirus Grift, NEW REPUBLIC (June 30, 2020), https://newrepublic.com/article/158337/big-pharmacoronavirus-grift; see also Peter B. Bach, Remdesivir Less Expensive for 'Government Programs.' Not So Fast, Drug Pricing Lab (2020), https:// drugpricinglab.org/wp-content/uploads/2020/07/Remdesivir-Paper-1.pdf (alleging that most U.S. government programs will pay full price for remdesivir). 33628 U.S.C. $\$ 1498(\mathrm{a})$.

${ }^{337}$ Advanced Software Design Corp. v. Fed. Reserve Bank of St. Louis, 583 F.3d 1371, 1378 (Fed. Cir. 2009).

338 See, e.g., HHS Press Release, supra note 321(Announcing that remdesivir "will be allocated [in July, August, and September 2020] in the same way that Gilead's donation of approximately 120,000 treatment courses of remdesivir were allocated: HHS allocates product to state and territorial health departments based on COVID-19 hospital burden, and health departments allocate it to hospitals."). 
the Strategic National Stockpile for public health emergencies, which would qualify as "use[] or manufacture[] by or for the United States," as Wang and Kesselheim have noted. 339

Second, trade secrets and internal know-how will pose minimal barriers to generic manufacturing. Remdesivir is a small molecule drug with a relatively simple formulation: the active ingredient is combined with an excipient that improves its stability and solubility to form a powder and then dissolved in water to form an injectable solution. ${ }^{340}$ Making remdesivir is nontrivial in practice: the active ingredient is somewhat complex to synthesize, as small molecules go, and formulation involves a days-long step - lyophilization - that requires specialized equipment. ${ }^{341}$ Yet the drug can be reverse engineered, and generic manufacturers overseas have already been able to develop formulations bioequivalent to Gilead's, quickly. ${ }^{342}$ For example, as of July 2020, one generic company in Bangladesh (Beximco) had scaled up its manufacturing of remdesivir from zero to 80,000 vials per month in less than three months, without authorization or assistance from Gilead. ${ }^{343}$ The same company

\footnotetext{
${ }^{339}$ Wang \& Kesselheim, supra note 15 , at 478.

${ }^{340}$ Gilead Scis., supra note 301.

${ }^{341}$ See Himani Chandna, Govt Steps up Pressure on Remdesivir-Makers to Increase Output, Crack down on Black Marketing, THEPRINT (July 23, 2020), https://theprint.in/health/govt-steps-up-pressure-on-remdesivir-makers-toincrease-output-crack-down-on-black-marketing/466887; Lisa M. Jarvis, Scaling up Remdesivir Amid the Coronavirus Crisis, CHEMICAL \& ENGINEERING News (Apr. 20, 2020), https://cen.acs.org/biological-chemistry/infectious-disease/ Scaling-remdesivir-amid-coronavirus-crisis/98/web/2020/04.

${ }^{342}$ See India's CDSCO Approves Generics of Favipiravir and Remdesivir for Covid-19 Treatment, Pharmaceutical Bus. Rev. (June 22, 2020), https://www. pharmaceutical-business-review.com/news/covid-19-india-favipiravirremdesivir/ (describing two generic formulations of remdesivir approved for sale in India); Zeba Siddiqui, Bangladesh's Beximco to Begin Producing COVID-19 Drug Remdesivir, REUTERS (May 5, 2020), https://www.reuters.com/article/ushealth-coronavirus-bangladesh-remdesi/exclusive-bangladeshs-beximco-tobegin-producing-covid-19-drug-remdesivir-coo-idUSKBN22H1DD (describing approval of generic remdesivir in Bangladesh, developed without Gilead's authorization or assistance); Ed Silverman, First Generic Version of Gilead's Remdesivir Will Be Sold by a Bangladesh Drug Maker, STAT (May 22, 2020), https:/www.statnews.com/pharmalot/2020/05/22/gilead-remdesivir-covid19coronavirus-beximco-patent/ (same).

${ }^{343}$ See A.Z.M. Anas, Bangladesh's Beximco Thrives on Coronavirus Challenges, NIKKEI ASIAN REV. (July 26, 2020), https://asia.nikkei.com/Business/ Pharmaceuticals/Bangladesh-s-Beximco-thrives-on-coronavirus-challenges.
} 
stated that it intends to expand production further, to 160,000 vials per month by the end of August 2020, and that it has already exported the drug outside of Bangladesh to five other countries. ${ }^{344}$ Another Bangladeshi generic company, Eskayef, has also developed a generic formulation of remdesivir without authorization or assistance from Gilead and has likewise exported the drug outside of Bangladesh. ${ }^{345}$ Numerous brand-name, generic, and contract drug manufacturers within the United States have the expertise and equipment necessary to manufacture remdesivir. For example, Pfizer announced in August 2020 that it would begin manufacturing remdesivir at a McPherson, Kansas factory that specializes in injectable medicines, under a contract with Gilead, as Gilead gradually (too gradually) responded to shortages. ${ }^{346}$

Third, manufacturers other than Gilead will likely be able to obtain the regulatory permission they need to distribute and sell remdesivir within the United States. ${ }^{347}$ Generic firms may not be

Perhaps counterintuitively, generic drug companies are often more, not less, innovative and successful than "innovator" brand-name drug companies at improving drug manufacturing processes, eliminating inefficiencies, and driving down the costs of production. Generics earn much smaller profit margins than brand-name drug companies and often compete fiercely with one another on price, sparking innovation in manufacturing processes that drives costs down. See Martha M. Rumore, The Hatch-Waxman Act-25 Years Later: Keeping the Pharmaceutical Scales Balanced, PHARMACY TIMES (Aug. 15, 2009), https:// www.pharmacytimes.com/publications/supplement/2009/

genericsupplement0809/generic-hatchwaxman-0809 ("[G]enerics innovate, often obtaining 'design-around' patents or a more efficient manufacturing process, new formulations, or new forms of the active ingredient"). For example, it was Cipla, a low-margin generic manufacturer, that figured out how to manufacture and sell HIV drugs for $\$ 1$ a day, a fraction of the manufacturing costs brand-name companies had incurred. See Sarah Boseley, Yusuf Hamied, Generic Drugs Boss, GUARDIAN (Feb. 18, 2003), https://www.theguardian.com/world/2003/feb/18/ aids.sarahboseley13.

344 See Anas, supra note 343.

${ }^{345}$ Eskayef Pharma's Remdesivir Is a Headache for Indian Drugmakers, Bus. STANDARD (June 9, 2020), https://bsnews.net/coronavirus-chronicle/eskayefpharmas-remdesivir-headache-indian-drugmakers-90691.

346 Press Release, Pfizer Inc., Pfizer Announces Agreement with Gilead to Manufacture Remdesivir for Treatment of COVID-19 (Aug. 7, 2020), https:// www.pfizer.com/news/press-release/press-release-detail/pfizer-announcesagreement-gilead-manufacture-remdesivir.

${ }^{347}$ Regulatory questions are admittedly complex and especially unpredictable in this moment of declared public health emergency. See G. Caleb Alexander, Aaron 
able to use the normal Abbreviated New Drug Application pathway for FDA approval based on any New Drug Application approval that Gilead receives, because Gilead is likely to receive, upon approval, some data exclusivity that will preclude such abbreviated applications. ${ }^{348}$ Instead, we see two distinct alternative paths for a competitor manufacturer to obtain permission. The first is an Emergency Use Authorization (EUA). At least as of writing, the FDA has not actually approved Gilead's remdesivir product; instead, the FDA has provided an EUA, which enables the HHS secretary to "authorize the introduction... of a drug, device, or biological product intended for use in an actual or potential emergency," even when that product "is not approved, licensed, or cleared for commercial distribution." 349 Gilead's EUA was authorized by the FDA on the basis of two trials, ${ }^{350}$ one of which was the earlier-

S. Kesselheim \& Thomas J. Moore, Searching for an Effective Covid-19 Treatment: Promise and Peril, STAT (Apr. 10, 2020), https://www.statnews.com/ 2020/04/10/searching-for-an-effective-covid-19-treatment-promise-and-peril/; Reynald Castaneda, FDA May Be Risk-Averse to Grant Emergency Use for Covid19 Vaccines, Clinical TRIALS ARENA (July 2, 2020), https://www. clinicaltrialsarena.com/comment/fda-covid-19-vaccines/; Leigh Turner, Could Pressure for COVID-19 Drugs Lead the FDA to Lower Its Standards?, CONVERSATION (June 10, 2020), https://theconversation.com/could-pressure-forcovid-19-drugs-lead-the-fda-to-lower-its-standards-139013.

${ }^{348}$ Gilead announced in August 2020 that it is seeking full FDA approval of remdesivir, based on the same trials that supported its EUA. See Press Release, Gilead Scis., Inc., Gilead Submits New Drug Application to U.S. Food and Drug Administration for Veklury (Remdesivir) for the Treatment of COVID-19 (Aug. 10, 2020), https://www.gilead.com/news-and-press/press-room/press-releases/ 2020/8/gilead-submits-new-drug-application-to-us-food-and-drugadministration-for-veklury-remdesivir-for-the-treatment-of-covid19. In the event that Gilead's application is approved, the FDA will grant Gilead a period of socalled "data exclusivity" that prohibits the filing of "abbreviated" applications on remdesivir for several years. See Frequently Asked Questions on Patents and Exclusivity, U.S. FOOD \& DRUG ADMIN. (May 2, 2020), https://www.fda.gov/ drugs/development-approval-process-drugs/frequently-asked-questions-patentsand-exclusivity.

${ }^{349}$ Federal Food, Drug, and Cosmetic Act $\S 564(\mathrm{a})(1)-(\mathrm{a})(2)(\mathrm{A}), 21$ U.S.C. $\S \S 360 \mathrm{bbb}-3$; see OFFICE OF COUNTERTERRORISM \& EMERGING THREATS, U.S. Dep'T of Health \& Human Servis., EMERgency Use Authorization of MEDICAL PRODUCTS AND RELATED AUTHORITIES: GUIDANCE FOR INDUSTRY AND OTHER STAKEHOLDERS 4 (2017), https://www.fda.gov/media/97321/download.

${ }^{350}$ See Letter from Denise M. Hinton, U.S. Food \& Drug Admin., to Ashley Rhoades, Gilead Scis., Inc. (May 1, 2020), https://www.fda.gov/media/137564/ download; see also Gilead Scis., supra note 301, at 33 (summarizing data from NIAID trial). 
mentioned clinical trial conducted (and paid for) by NIAID, which showed that remdesivir helps hospitalized patients with severe COVID-19 recover and leave the hospital more quickly than a placebo. ${ }^{351}$ According to news reports, this trial was apparently the more important of the two trials that supported the authorization, ${ }^{352}$ and it recently formed the sole basis of conditional approval by Canada's drug regulator. ${ }^{353}$ NIAID has committed to sharing the "[c]omplete de-identified patient data set" from its trial with any who ask for it, once the clinical study report has been finalized. ${ }^{354}$ As such, it seems likely to us that a generic manufacturer seeking an EUA from the FDA for its own remdesivir product will be able to obtain one by obtaining and submitting the complete data set from the NIAID trial along with proof that its product is bioequivalent to Gilead's. ${ }^{355}$ Generic manufacturers may also be able to submit, and rely on, clinical trial data from other publicly funded trials of remdesivir. ${ }^{356}$ A second path would be for a generic to file a full New Drug Application. Any FDA-granted data exclusivity for Gilead would not prevent a competitor manufacturer from submitting a complete (rather than an abbreviated) application for full FDA approval of its own, based on the NIAID trial and other publicly

\footnotetext{
${ }^{351}$ See supra notes 303-307.
}

${ }^{352}$ See, e.g., Maggie Fox et al., FDA Will Reportedly Authorize Use of Remdesivir for Covid-19 After Trial Shows "Positive Effect" on Recovery Time, CNN (Apr. 30, 2020), https://www.cnn.com/2020/04/29/health/gilead-sciences-remdesivircovid-19-treatment/index.html.

353 See Health Canada Authorises Remdesivir as First Covid-19 Treatment, PharmaceuticAl TeCH. (July 29, 2020), https://www.pharmaceuticaltechnology.com/news/canada-approval-remdesivir-covid/ (describing conditional approval); Gilead Sciences Canada, Inc., Product Monograph Including Patient Medication Information: Veklury, VEKLURY 1, 13 (July 27, 2020), https://pdf.hres. ca/dpd_pm/00057134.PDF (referring to the NIAID trial, and only the NIAID trial).

354 See Data Sharing Statement, https://www.nejm.org/doi/suppl/10.1056/ NEJMoa2007764/suppl_file/nejmoa2007764_data-sharing.pdf, in Beigel et al., supra note 304.

${ }^{355}$ See 21 C.F.R. $\S \S 320.21-.63$.

356 See, e.g., "Solidarity" Clinical Trial for COVID-19 Treatments, WORLD HEALTH ORG. (last updated July 6, 2020), https://www.who.int/emergencies/ diseases/novel-coronavirus-2019/global-research-on-novel-coronavirus-2019ncov/solidarity-clinical-trial-for-covid-19-treatments; Trial of Treatments for COVID-19 in Hospitalized Adults (DisCoVeRy), U.S. NAT'L LIBR. MED. (last updated July 22, 2020), https://clinicaltrials.gov/ct2/show/NCT04315948. 
available data. ${ }^{357}$

That legal, logistical, and regulatory barriers are traversable makes remdesivir perhaps unlike some other anti-COVID medical products. In particular, with respect to vaccines, several scholars have focused on trade secret knowledge of manufacturing processes, observing that "the more significant impediments to producing a successful coronavirus vaccine lie on the manufacturing side" and are not patents themselves. ${ }^{358}$ (Vaccines and other biological drug products are often more difficult for competitors to reverse engineer than small molecule drugs. ${ }^{359}$ ) As a result, these scholars contend that use of $\S 1498$ could be counterproductive; it could, they argue, erode a patent holder's financial incentives to scale up manufacturing and distribution of the patented vaccine without concomitantly empowering competitors to make it, leaving the

${ }^{357}$ See 21 U.S.C. $\$ 355(b)(1)$ (permitting filing of applications based on "full reports of investigations which have been made to show whether or not such drug is safe for use and whether such drug is effective in use"); Rebecca S. Eisenberg, Data Secrecy in the Age of Regulatory Exclusivity, in THE LAW AND THEORY OF TRADE SECRECY: A HANDBOOK OF CONTEMPORARY RESEARCH 467, 488 (Rochelle C. Dreyfuss \& Katherine J. Strandburg eds., 2011) ("[R]egulatory exclusivity defers the filing and approval of ANDAs, but not of NDAs. An applicant who is able to submit 'full reports of investigations which have been made to show whether or not such drug is safe for use and whether such drug is effective in use' need not wait until the end of the exclusivity period, when the statute permits the use of an ANDA, but could instead file an NDA. ... [I]f the data were publicly available, the competitor could file its own NDA at reasonable cost."); Erika Lietzan, A New Framework for Assessing Clinical Data Transparency Initiatives, 18 MARQ. INTELL. PROP. L. REV. 33, 67 (2014) (" $[\mathrm{W}]$ here the [clinical trial] data is released and available, an abbreviated application may not be required by the regulator. A full application can be submitted. This effects an end run around regulatory exclusivity, which prohibits only approval, or sometimes submission, of abbreviated applications.").

${ }^{358}$ Nicholson Price et al., Are COVID-19 Vaccine Advance Purchases a Form of Vaccine Nationalism, an Effective Spur to Innovation, or Something in Between?, WRITTEN DESCRIPTION (Aug. 5, 2020), https://writtendescription.blogspot.com/ 2020/08/are-covid-19-vaccine-advance-purchases.html; accord Ken Shadlen, Speeding up the Development and Distribution of COVID-19 Vaccines, ISSUES SCI. \& TECH. (Aug. 11, 2020), https://issues.org/covid-vaccines-developmentdistribution-patenting-shadlen/ ("For some COVID products (vaccines in particular), the [principal] barriers to access will be related to their production ....").

${ }^{359}$ See Sara Eve Crager, Improving Global Access to New Vaccines: Intellectual Property, Technology Transfer, and Regulatory Pathways, 108 AM. J. PUB. HEALTH S414, S415 (2018), https://ajph.aphapublications.org/doi/pdfplus/10. 2105/AJPH.2014.302236r. 
world with less supply than ever. ${ }^{360}$ These scholars specifically contend that use of $\S 1498$ and other compulsory patent licensing could impede transfer from the patent holder to those competitors of the vital knowledge those competitors need. ${ }^{361}$

There are several reasons to think that knowledge transfer will not be as much a problem in the context of COVID-19 vaccines as these commentators suggest, even if $\S 1498$ is on the table. The premise is that government patent use will lead patent holders to refuse knowledge transfer, but in fact history repeatedly shows that government patent use leads patent owners to be more conciliatory in negotiations; lack of government power has tended to give rise to patentee recalcitrance. ${ }^{362}$ In our view it is more likely that exercise of $\S 1498$ or the threat of its exercise would encourage patent holders to make deals with the government that include elements of knowledge transfer. Furthermore, in cases of extreme impasse, the government may be able to compel technology transfer-including transfer of trade secret manufacturing information - via authority to "allocate materials" under the Defense Production Act. ${ }^{363}$

In a larger sense, the fact that $\S 1498$ cannot overcome trade secrets, regulatory exclusivities, and other barriers to emergency response reflects an ongoing failure to consider how these nonpatent forms of intellectual property intersect with crises. Even $\S 1498$ itself was not the product of thinking about patents in national emergencies; it arose out of a very non-emergency Capitol renovation. ${ }^{364}$ That $\S 1498$ has ended up playing a role in past national emergencies suggests a need for Congress to consider $\S 1498$-like statutory authority on trade secrets, regulatory exclusivities, and other competition barriers, as some scholars have argued it should, ${ }^{365}$ so that the U.S. government can better accelerate competition in the event of shortages, price-gouging, or other

${ }^{360}$ See Shadlen, supra note 358; Price et al., supra note 358.

361 See Shadlen, supra note 358; Price et al., supra note 358.

362 See supra notes $158-165$ and accompanying text.

36350 U.S.C. $\S \S 4511(\mathrm{a})(2) \& 4552(13)$ (defining "materials" to include "technical information"); Quigley, supra note 216. Of course, the government would need to weigh the costs and benefits before exercising the DPA, just as it should with exercise of $\S 1498$.

${ }^{364}$ See supra Part I.A.

365 See, e.g., Yaniv Heled, The Case for Disclosure of Biologics Manufacturing Information, 47 JOURNAL OF LAW, MEDICINE \& ETHICS 54 (2019); Ameet Sarpatwari et al., The US Biosimilar Market: Stunted Growth and Possible Reforms, 105 CLINICAL PHARMACOLOGY \& THERAPEUTICS 92 (2018). 
problems.

\section{Government Patent Use Offers a Way Forward}

Patents, then, are the major barrier to competitive manufacturing of remdesivir, and there is a straightforward solution to overcoming shortages and excessive pricing: The U.S. government, and HHS specifically, could use government patent use under $\S 1498$ to permit other manufacturers to make and sell remdesivir in the United States. HHS can and should publicly commit now to using $\S 1498$, so that the United States' supply of affordable remdesivir is assured. ${ }^{366}$

The normative case for the U.S. government use of $\S 1498$ to procure remdesivir is based on our framework. All four advantages of government patent use are highly salient in the case of remdesivir and COVID-19. Government patent use is clearly preferable to a U.S. government buyout of Gilead's patents, which other scholars have proposed. ${ }^{367}$

First, speed is critical. As noted above, as of writing, the United States and other countries have already faced shortages of remdesivir that hinder doctors' ability to treat their patients, and these shortages could continue into the fall and beyond. ${ }^{368}$ HHS must do whatever it can to get additional supply of remdesivir into the marketplace as quickly as possible. To this end, HHS can and should announce its intent now to authorize other manufacturers (besides Gilead) under $\S 1498$ to manufacture, import, export, distribute, and sell remdesivir. HHS can do this instantly. By contrast, negotiating a patent buyout or licensing deal with Gilead could take many months. Some delay in getting alternative manufacturers to market is inevitable; Gilead's competitors will need to scale up manufacturing and clear the regulatory hurdles

\footnotetext{
${ }^{366}$ One of us (C.J.M.) has previously advocated in shorter pieces for government patent use to expand access to remdesivir. See supra note 295. In July 2020, the legal scholar Amy Kapczynski and the medical researchers and practicing physicians Paul Biddinger and Rochelle Walensky published an op-ed advocating the same. Kapczynski, Biddinger \& Walensky, supra note 12. To be clear, committing to use $\S 1498$ does not require actually using it if the patent holder puts an appropriate deal on the table, in the same way that the threat of invoking $\S 1498$ prodded Bayer to negotiate on Cipro. See supra notes 124-125. But without a clear commitment, patent holders may not feel the same need to negotiate in good faith or with expediency. See supra notes 158-165.

${ }^{367}$ Hemel \& Ouellette 2020b, supra note 31 (proposing that HHS buy the patent rights to remdesivir from Gilead).

${ }^{368}$ See supra notes $316-327$ and accompanying text.
} 
noted above. But these practical hurdles will arise regardless of whether a buyout or government patent use is used. A buyout simply introduces extra delay.

Second, the flexibility of government patent use is advantageous here. We trace here two options for HHS-an ambitious intervention, under which all of the government's need for remdesivir is met through government patent use, and a modest one, under which the government would authorize generic manufacturing under $\S 1498$ and stockpile a smaller supply of doses, to keep on hand in case of shortages.

Under the more ambitious option, HHS could bypass Gilead altogether and contract with one or more generic drug companies who are able to supply the drug cheaply, much closer to manufacturing cost than the thousands of dollars per course of treatment that Gilead is charging. To bypass Gilead altogether would mimic what the U.S. government threatened to do when Bayer refused to reduce the price or increase supply of ciprofloxacin in the 2001 anthrax crisis. ${ }^{369}$ It would also mimic the proposals of Brennan et al., ${ }^{370}$ Senators Bernie Sanders ${ }^{371}$ and Elizabeth Warren, ${ }^{372}$ and the editorial board of The New York Times, ${ }^{373}$ all of whom have called on the U.S. government to use $\S 1498$ to move its spending from expensive brand-name to cheap generic versions of certain drugs. A generic manufacturer in Bangladesh is manufacturing and selling a generic version of remdesivir at a cost of between $\$ 295$ and $\$ 781$ (USD) per course of treatment, ${ }^{374}$ and generics in India are selling remdesivir at a similar price. ${ }^{375}$ (The marginal cost is surely

\footnotetext{
${ }^{369}$ Supra Part I.D.

${ }^{370}$ Brennan et al., supra note 11, at 346 (calling on government procurement officers to contract directly with generic companies to purchase hepatitis $\mathrm{C}$ drugs instead of purchasing any such drugs from Gilead).

${ }^{371}$ Sanders, supra note 11.

372 Anderson, supra note 14.

${ }^{373}$ Editorial Bd., supra note 11.

374 See Silverman, supra note 342; Siddiqui, supra note 342.

375 See Sohini Das \& Vinay Umarji, Covid-19: At Rs 2,800 per Dose, Zydus Launches Cheapest Remdesivir Brand, BUS. STANDARD (Aug. 13, 2020), https:// www.business-standard.com/article/current-affairs/zydus-cadila-s-cheapestremdesivir-brand-to-disrupt-indian-market-120081301528_1.html; Angus Liu, WuXi NextCODE Rebrand; Remdesivir Generic Prices; Sinopharm COVID-19 Vax Phase 3, FIERCEPHARMA (June 26, 2020), https://www.fiercepharma.com/ pharma-asia/fiercepharmaasia-wuxi-nextcode-rebrand-remdesivir-generic-
} 
even lower, and costs of manufacturing may decline further as generics grow more experienced.) Should these generic manufacturers supply the United States at similar prices to those in South Asia, then payers would reap enormous savings compared to Gilead's current prices of $\$ 2,340$ to $\$ 3,120$. (Even HHS and the U.S. government, which would be required to pay Gilead "reasonable and entire compensation" for use of its patents, would come out far ahead, as we show below.)

Alternatively, HHS could make a more modest intervention under $\S 1498$, one that would trouble Gilead's business expectations only minimally while simultaneously protecting the American public from a shortage of remdesivir. Under this proposal, HHS could continue to purchase remdesivir from Gilead at Gilead's full price, at whatever rate Gilead is able to supply and sell, while simultaneously contracting with a generic manufacturer to build a stockpile. The stockpile could be reserved to ameliorate shortages and deployed (and replenished) only as needed. HHS would provide compensation to Gilead for its purchases of the generic. And Gilead's existing business-selling remdesivir to HHS and other buyers around the world-would continue.

Third, ex post determination of the appropriate compensation is highly beneficial in the case of remdesivir. Because of skimpy clinical trials and only a few months of real-world evidence, remdesivir's value is currently highly uncertain. ${ }^{376}$ Remdesivir could prove our best therapeutic weapon against COVID-19, or it could be supplanted by drugs that are more effective or cheaper-or by a vaccine. ${ }^{377}$ That makes a patent buyout particularly difficult from both Gilead's and the government's perspective: how to factor all that uncertainty? Use of $\S 1498$ would helpfully defer the question of patent valuation and compensation until after more evidence of remdesivir's therapeutic properties and sales has been

prices-sinopharm-covid-vax, (explaining that generic remdesivir in India will cost "around $\$ 350$ to $\$ 700$ per treatment course, depending on which doses a patient needs"); Anuron Kumar Mitra \& Siddharth Cavale, India's Cipla Prices Its Generic Remdesivir at \$53.34 per Vial, Below Rivals, REUTERS (July 8, 2020), https://www.reuters.com/article/us-health-coronavirus-cipla-idUSKBN2492Q3.

376 See Garde \& Silverman, supra note 332; Sarpatwari et al., supra note 303. Perhaps the most critical currently unanswered question is whether remdesivir reduces mortality - i.e., saves lives - or merely accelerates recovery in patients who would survive even without the drug.

377 See Silverman, Gilead's Pricing, supra note 333. 
gathered. Indeed, to ensure a solid evidence base, HHS could concomitantly work with the FDA (a constituent agency) to create a patient registry that collects information on patient outcomes from doctors who prescribe the drug, as Sarpatwari, Kaltenboeck, and Kesselheim have suggested. ${ }^{378}$ HHS could also sponsor new clinical trials through the National Institutes of Health (another constituent agency) to generate better evidence of remdesivir's therapeutic properties.

Finally, the fourth key feature of $\S 1498$, determination of that compensation by an impartial adjudicator, is likely to be advantageous as well. Placing the question of compensation in the hands of an objective judge rather than Gilead's negotiators is likely preferable from the government's (and public's) perspective, as Gilead has a reputation for price gouging and bad faith, even in its dealings with the U.S. government. ${ }^{379}$ Given Gilead's track record, a patent buyout raises the prospect of hold-up and worse.

What compensation would HHS pay if chose to use $\S 1498$ to authorize generic manufacturers to make and sell remdesivir?

${ }^{378}$ See Sarpatwari et al., supra note 303; see also Peter B. Bach, U.S. Hospitals Need to Study How Well Remdesivir Really Works, BloOMBerg L. (July 13, 2020), https://www.bloomberg.com/opinion/articles/2020-07-13/u-s-hospitalsneed-to-study-how-well-remdesivir-really-works.

${ }^{379}$ In 2015, a bipartisan investigation of Gilead's Hepatitis C drug portfolio by Senators Wyden (D-OR) and Grassley (R-IA) concluded that "Gilead's marketing, pricing, and contracting strategies were focused on maximizing revenue - even as the company's analysis showed a lower price would allow more people to be treated - not only for [its first FDA-approved Hepatitis C product], but more importantly for its follow-on . . . product pipeline." STAFFS OF RANKING MEMBER Ron Wyden \& COMM. MEMBER ChARLES E. GRASSLEy, 114TH CONG., The Price of Sovaldi and Its ImPact on the U.S. Health Care System 117 (Comm. Print 2015), https://www.finance.senate.gov/download/the-price-ofsovaldi-and-its-impact-on-the-us-health-care-system-full-report. The same report criticized Gilead's lack of candor, observing that "despite the company's assurances of cooperation, Gilead failed to produce all relevant documents and supporting materials." Id. Gilead is also currently embroiled in a patent infringement lawsuit filed by the U.S. Department of Justice and Department of Health and Human Services (HHS), which alleges that Gilead acted in bad faith in negotiating a patent license to government-held patents with HHS and one of its constituent agencies, the Centers for Disease Control and Prevention. See Complaint at 1-4, United States v. Gilead Scis., Inc., No. 1:19-cv-2103 (D. Del. Nov. 6, 2019) ("Gilead's conduct was malicious, wanton, deliberate, consciously wrongful, flagrant, and in bad faith. This is especially true because ... the Government has attempted to negotiate [a patent license] in good faith ...."); $i d$. at 69 . 
Assuming conservatively that HHS pays a sale price of $\$ 800$ to the generic for a standard course of treatment (higher than the highest generic prices currently charged overseas) and pays to Gilead a very generous court-set royalty of $50 \%$ of that sale price ${ }^{380}$ HHS would still spend a total of only $\$ 1,200$ per course of treatment - far less than Gilead currently charges. HHS, and American taxpayers, would come out ahead.

And Gilead itself would fare well at the Court of Federal Claims; despite "breaking" Gilead's patent, this scenario is no "nuclear option." After going to court to claim its compensation from the U.S. government, Gilead would collect a royalty that could run to the hundreds of millions, ${ }^{381}$ even billions, ${ }^{382}$ of dollars, all while foregoing the manufacturing and distribution costs it would incur if it made the infringing doses itself - while simultaneously selling remdesivir at whatever price it pleases to payers in other countries around the world, and perhaps to private payers in the United States not supplied by HHS. Between royalties and its own sales, Gilead should quickly recoup the "up to $\$ 1$ billion or more" it has contended (without documentation) that it ultimately plans to invest in remdesivir. ${ }^{383}$

Determination of compensation at the Court of Federal Claims has another interesting advantage in the case of remdesivir: the court can adjudicate not only compensation but also ownership of the patents that cover remdesivir. A report recently co-authored by Krellenstein and one of the authors concluded that the U.S. government likely co-owns (with Gilead) the patents on remdesivir itself as well as the method of treating COVID-19 with

380 A $50 \%$ royalty would be extraordinarily high, making our estimates conservative (from the government's perspective). See supra note 194 (observing that royalties of over $10 \%$ are rare in $\S 1498$ cases).

381 Assuming a royalty of $\$ 400$ on 500,000 doses, Gilead would receive $\$ 200,000,000$.

382 Assuming a royalty of $\$ 400$ of $5,000,000$ doses, Gilead would receive $\$ 2,000,000,000$.

383 Sydney Lupkin, Putting a Price on COVID-19 Treatment Remdesivir, NPR (May 8, 2020), https://www.npr.org/sections/health-shots/2020/05/08/851632704 /putting-a-price-on-covid-19-treatment-remdesivir. HHS's contract with Gilead to distribute 500,000 doses of remdesivir at Gilead's full monopoly price between July and September 2020 may alone suffice to guarantee Gilead a payout of over $\$ 1 B$, likely sufficient to cover all of Gilead's purported costs. See Bach, supra note 335 . 
remdesivir. ${ }^{384}$ This rather unusual feature of remdesivir arises from the fact that it was co-developed by Gilead and U.S. government scientists rather than by Gilead alone. This feature makes government patent use particularly appealing from the government's (and public's) perspective: for any patents that the U.S. government is able to prove it co-owns, the "reasonable and entire compensation" the government will owe under $\S 1498$ for use of these patents will be zero. ${ }^{385}$ HHS would owe compensation only for use of any patents that Gilead owns outright, without coownership by the U.S. government. ${ }^{386}$ Under U.S. patent law, HHS would owe no compensation to Gilead for use of any patent of which the U.S. government turns out to be rightful co-owner. ${ }^{387}$ The consequent savings to HHS would represent a kind of compensation for the U.S. government's investment in that patent-and, more broadly, compensation for the more than $\$ 70,000,000$ that the American public invested in the early, riskiest days of remdesivir's development. $^{388}$

All four of the key beneficial features of government patent use under $\S 1498$ thus weigh in favor of its use on remdesivir. The end result of government patent use on remdesivir would be increased competition, greater supply, and lower prices-much lower for patients and private payers, who would pay only the price that generic makers charge, and substantially lower even for the U.S. government, who would pay that price plus court-set compensation to Gilead. Given the unique circumstances around remdesivir-not

${ }^{384}$ Krellenstein \& Morten, supra note 295; see also Dani Kass, Activists Say Gov't Should Have Rights to Remdesivir Patents, LAw360 (May 27, 2020), https://www. law360.com/ip/articles/1277114/activists-say-gov-t-should-have-rights-toremdesivir-patents.

${ }^{385}$ If the U.S. government co-owns these patents, it has a legal right to license them as it pleases, including to generic pharmaceutical companies, without permission from or payment to Gilead. See 35 U.S.C. $§ 262$ ("In the absence of any agreement to the contrary, each of the joint owners of a patent may make, use, offer to sell, or sell the patented invention within the United States, or import the patented invention into the United States, without the consent of and without accounting to the other owners.").

${ }^{386}$ Krellenstein \& Morten, supra note 295, at 15.

387 See 35 U.S.C. $\$ 262$ ("In the absence of any agreement to the contrary, each of the joint owners of a patent may make, use, offer to sell, or sell the patented invention within the United States, or import the patented invention into the United States, without the consent of and without accounting to the other owners.").

388 See supra note 332. 
least the scale of the public health crisis posed by COVID-19 and the deep involvement of HHS scientists in remdesivir's invention and clinical development-HHS should commit now to using this policy tool to protect public health.

\section{CONCLUSION}

Section 1498 has long played and ought to continue playing its part in U.S. patent policy. In emergencies past, it has resolved widescale tragedies, and it has clear applications, large and small, in the COVID-19 crisis. Section 1498's long pedigree and theoretical advantages dispel the notion that it is antithetical to the modern patent system. It is part and parcel of our patent system, and its advantageous features recommend its use alongside other policy tools for driving innovation and expanding access to patented technologies.

While we conclude that $\S 1498$ has an important role in patent policy and thus reject the view that invocation of the statute is exceptional, impractical, or extreme, we have not established a specific test for when $\S 1498$ should or should not be used, and we do not purport to. Instead, we have identified neglected features of $\S 1498$ that make it a valuable policy tool that could be applied more widely than it has been in recent decades and yield significant social and economic benefits in a wide set of situations, especially-but not only-in times of national emergency. An important area of further research will be the development of more detailed and specific guidance on when invocation of $\S 1498$ is wise as a matter of policy, in view of those advantages and disadvantages that we and others have identified.

That the role of $\S 1498$ in the context of national emergencies has not been explored in depth to date suggests a larger need for research on the relationship of the patent system generally with imminent conditions that require federal response. As one of us has observed in a study of patents and national security, ${ }^{389}$ traditional narratives of patent policy, though applicable in usual circumstances, do not necessarily hold up when there are nationalscale interests at stake. It is our hope that the calamitous circumstances that we face today with COVID-19 will encourage further research into how a system as complex and broad-reaching as U.S. patent law can accommodate the challenges-emergency and routine - that may lie ahead.

${ }^{389}$ See Duan, supra note 48. 
V. APPENDIX: MEMORANDUM FROM ALFRED B. ENGELBERG TO SENATOR CHARLES E. SCHUMER

Alfred B. Engelberg

INCREASING ACCESS TO CIPRO

A Strategy for Rapid Creation of a Government Stockpile

October 13, 2001

\section{Background Facts}

Panic buying of CIPRO in response to recent threats of bioterrorism involving Anthrax has caused massive shortages of this antibiotic. The ability to create new supplies is limited by the fact that the drug is patented until at least December 2003 and is only available from a single source. A challenge to the validity of the patent which might have resulted in the widespread availability of a low cost generic alternative was settled when the patent owner, Bayer Corporation, reportedly paid Barr Laboratories and others in excess of $\$ 200$ million to drop the challenge. The FTC is investigating this settlement as a possible anti-trust violation and several class action antitrust cases have been commenced on behalf of consumers. At the present time at least five generic drug manufacturers have been tentatively approved to manufacture ciprofloxacin, the generic version of CIPRO but, due to the existence of the Bayer patent, they cannot begin the commercial manufacture and sale of generic product until the Bayer patent expires more than 2 years from now.

\section{Current Law Permits the United States to Purchase Generic Ciprofloxacin Now}

The United States government and its suppliers are immune from suits for patent infringement in the Federal District Courts The sole and exclusive remedy for an act of infringement by or for the government is a suit against the United States in the Court of Claims pursuant to 28 U.S.C. $\S 1498$ (a). The statute reads as follows:

(a) Whenever an invention described in and covered by a patent of the United States is used or manufactured by or for the United States without license of the owner thereof or lawful right to use or manufacture the same, the owner's remedy shall be by action against the United States in the United States Claims Court for the recovery of his reasonable and entire compensation for such use and manufacture. 
For the purposes of this section, the use or manufacture of an invention described in and covered by a patent of the United States by a contractor, a subcontractor, or any person, firm, or corporation for the Government and with the authorization or consent of the Government, shall be construed as use or manufacture for the United States.

No injunction is available under $\S 1498$ and the only remedy is reasonable compensation for the unauthorized use of an invention. But the government has the right to assert any defense to compensation that a private party could assert, namely that the patent is invalid, not infringed or unenforceable. Under federal procurement regulations, the government is often (although not always) indemnified against claims for compensation by its suppliers and the suppliers assist in asserting these defenses. Accordingly, the government may assert the same challenges to the CIPRO patent that have been asserted by Barr and are now being asserted by others. ${ }^{390}$

There is ample authority for the proposition that 28 U.S.C. $\S$ 1498(a) prevents a Federal District court from issuing an injunction against a government supplier that would interfere with the right of that supplier to bid on and participate in the sale of products to the government. Gore v. Garlock, 842 F.2d 1275, 1282 (Fed. Cir. 1988). In fact, that principle has been applied by the courts even in cases where the same supplier was actually enjoined from making commercial sales of the same product. As stated by the Federal Circuit Court of Appeals in Garlock:

The patentee takes his patent from the United States subject to the government's eminent domain rights to obtain what it needs from manufacturers and to use the same. The government has graciously consented in the same statute, to be sued in the claims court for reasonable and entire compensation, for what would be an infringement by a private person. The same principles apply to injunctions which are nothing more than the giving of aid of the courts to the enforcement of the patentees right to exclude. Though injunctions may seem to say that making for and selling to the

${ }^{390}$ It is noteworthy that the U.S. government has actually used its authority under 28 U.S.C. $\S 1498$ to procure a less expensive generic version of a patented drug (Miltown) from abroad. See Carter Wallace v. United States, 449 F2d 1374 (U.S. Ct. Clms. 1972). 
government is forbidden, injunctions based on patent rights cannot in reality do that because of $\S 1498(a)$.

Quoting the foregoing paragraph in Trojan v. Shat-R-Shield, 885 F.2d 854 (Fed. Cir. 1989), the Federal Circuit further stated:

In short, a patent owner may not use its patent to cut the government off from sources of supply, either at the bid stage or during performance of a government contract.

In the face of these overwhelming precedents, Bayer is likely to argue that $\S 1498$ is not applicable to generic drug purchases because a mere applicant for approval of an ANDA is not yet a legitimate competitor for a government contract and, therefore, the act of filing and seeking approval for an ANDA does not have the "authorization and consent" from the government that is a prerequisite to invoking 28 U.S.C. $§ 1498$. The Federal Circuit Court of Appeals rejected a similar argument in TVI Energy Corp. v. Blane, 806 F.2d 1057 (Fed. Cir. 1986). As the Federal Circuit noted, $\S 1498$ protects government procurement activities, including acts required to satisfy government procurement requirements and that authorization and consent can be implied and need not be expressly stated by the government.

Despite the foregoing precedents, the government could easily moot any possibility of protracted litigation by issuing a blanket "authorization and consent" for generic manufacturers holding tentative ANDA approvals to submit bids to the appropriate agencies. Such an authorization, which could be issued by OMB, HHS or some other agency with responsibility for drug procurement, would eliminate any basis for litigation. At least five companies now have tentative approvals to manufacture ciprofloxacin and are prevented from full approval solely because of the Bayer patents.

3. Generic Versions of Licensed Drugs Can Be Approved By the FDA Notwithstanding the Patent Certification Procedures Required Under Current Law

Under current law, the FDA will not approve a generic version of a drug for which unexpired patents are listed in the Orange Book unless the applicant makes a Paragraph IV certification alleging that a patent is invalid, unenforceable or will not be infringed. When such a certification is made the FDA is prohibited from approving 
the generic drug for 30 months unless a court issues a judgment in a shorter time. An applicant seeking approval for the purpose of marketing a drug solely to the United States government can file a paragraph IV certification and state "Applicant will not infringe U.S. Patent No. __ because the product of this application will only be sold to the United States." If a supply agreement has already been authorized by a government agency, documentation of the authorization and consent should accompany the certification.

In all likelihood, the patent owner will sue the first generic applicant that seeks an approval for the exclusive purpose of making sales to the government. Any competent Federal District Court will be compelled to summarily dismiss any such lawsuit on the basis of the precedents cited in this memo. Indeed, it would be appropriate for the ANDA applicant to specifically request and for the court to grant, an immediate final judgment compelling the FDA to grant approval of any ANDA for the purpose of allowing the applicant to sell product to the United States government. At least two generic manufacturers with tentatively approved ANDAs for ciprofloxacin are already engaged in litigation with respect to the Bayer patents. Those parties are in a position to file immediate motions for summary judgment of non-infringement based on the legal theory outlined herein and to by-pass the loss of time that would occur before litigation begins if the normal patent certification process is followed.

\section{Timetable \& Risk}

Assuming that one of the two generic companies now involved in litigation with Bayer is willing to proceed, a motion for summary judgment of non-infringement could be filed, on an expedited or emergency basis, in a Federal District Court in a matter of a couple of days simply by relying on the legal arguments in this memo. There would, however, be no point in doing so without a firm commitment of the US government to make a substantial purchase at a pre-negotiated price. Obviously that price would be heavily discounted as compared to the current wholesale price of the patented product. The contract commitment is essential from both an incentive standpoint and to eliminate any possibility of a legal skirmish on the issue of authorization and consent.

One significant stumbling block could be the issue of who assumes the risk of paying "reasonable compensation" in the event Bayer sues the U.S. for patent infringement and the patent is upheld. 
The generic manufacturers will be highly reluctant to assume any portion of that risk since a large award could destroy their business. Moreover, the risk may be real. On February 9, 2001, the U.S. District Court for the District of New Jersey denied a motion for Summary Judgment by Mylan and Schein to declare the basic Bayer patent to be invalid and specifically held the patent valid over the challenge asserted in that motion. At this time, it is unknown whether there are other grounds for challenging the patent or whether the summary judgment decision would be affirmed on appeal. Moreover, there is a substantial question as to whether the patent will ultimately be enforceable in view of the antitrust issues surrounding the settlement with Barr Laboratories. Given the significant benefit to the government of assuring the existence of an adequate supply of ciprofloxacin and the ability to procure that supply at a relatively low cost, the government may wish to consider waiving or limiting the usual indemnification provisions in federal procurement contracts.

Preliminary investigation reveals that a supply of bulk active ingredient is available from reputable FDA-approved sources abroad and that delivery of significant quantities of finished product could commence within 60-90 days assuming the legal obstacles have been cleared away and FDA approval is in hand. 